\title{
Duration of antibacterial treatment for uncomplicated urinary tract infection in women (Review)
}

\author{
Milo G, Katchman EA, Paul M, Christiaens T, Baerheim A, Leibovici L
}
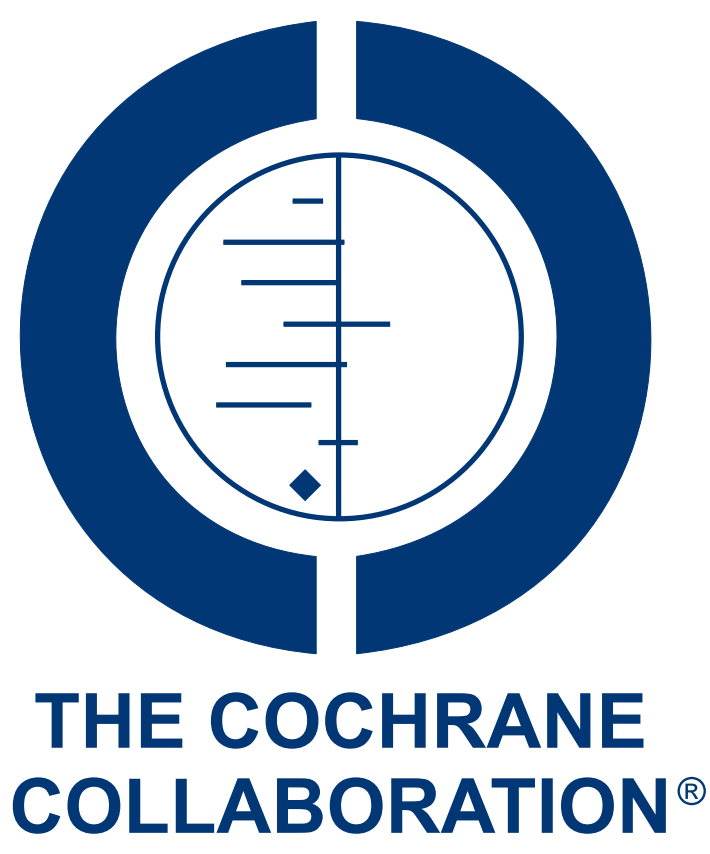

This is a reprint of a Cochrane review, prepared and maintained by The Cochrane Collaboration and published in The Cochrane Library 2007, Issue 1

http://www.thecochranelibrary.com

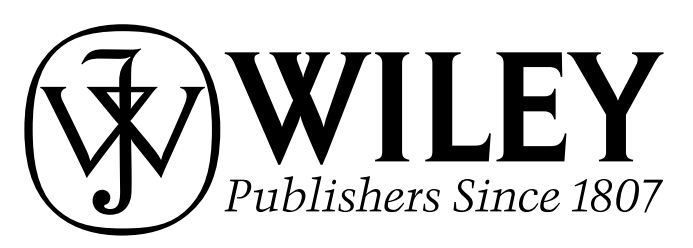

Duration of antibacterial treatment for uncomplicated urinary tract infection in women (Review)

Copyright $\odot 2007$ The Cochrane Collaboration. Published by John Wiley \& Sons, Ltd 
TABLE OF CONTENTS

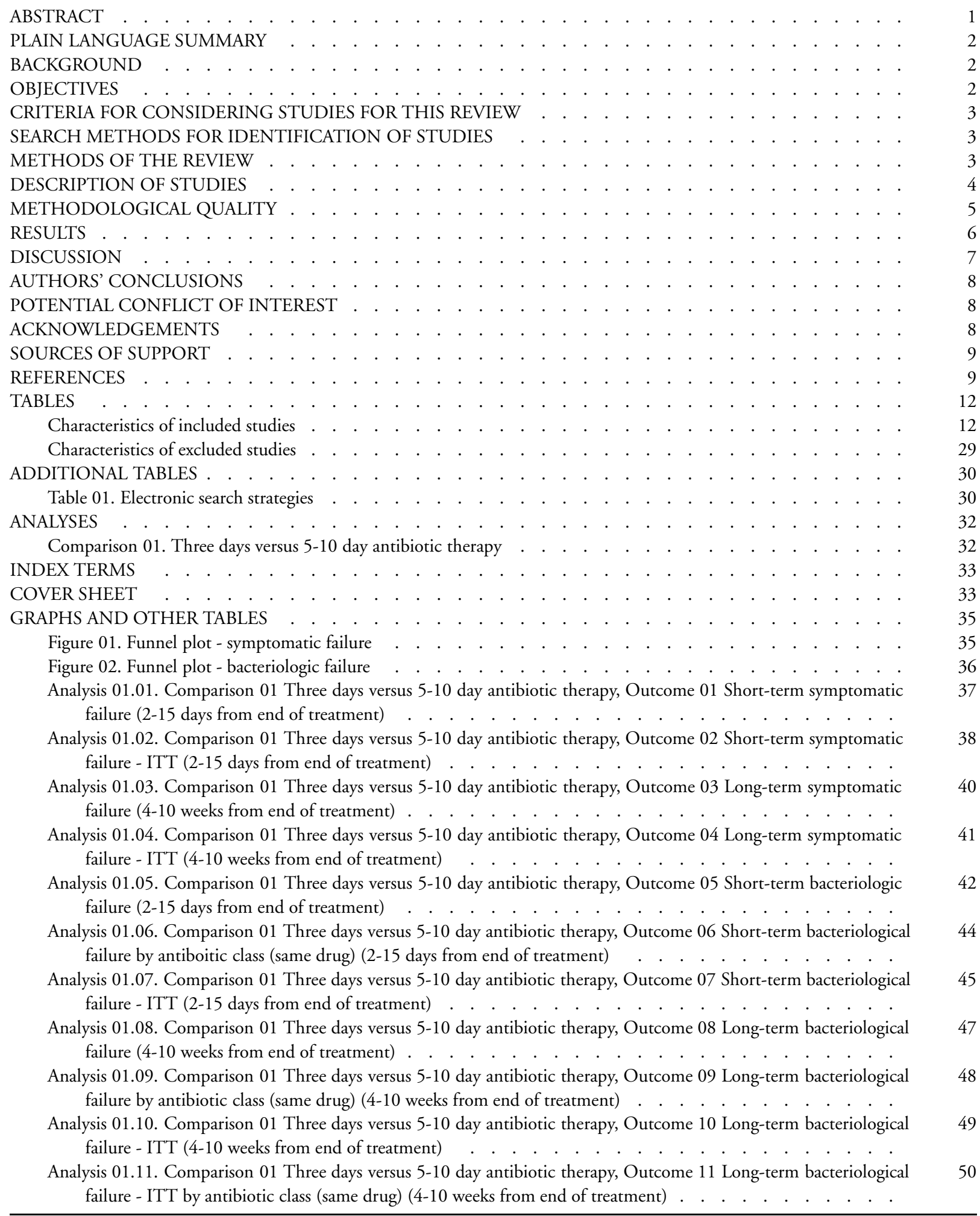

Duration of antibacterial treatment for uncomplicated urinary tract infection in women (Review)

Copyright ( 2007 The Cochrane Collaboration. Published by John Wiley \& Sons, Ltd 
Analysis 01.12. Comparison 01 Three days versus 5-10 day antibiotic therapy, Outcome 12 Patients with any adverse effects during treatment . . . . . . . . . . . . . . . . . . . . . . . . . . . . . .

Analysis 01.13. Comparison 01 Three days versus 5-10 day antibiotic therapy, Outcome 13 Patients developed pyelonephritis . . . . . . . . . . . . . . . . . . . . . . . . . . . . . . . . . . . . . . . . . . . .

Analysis 01.14. Comparison 01 Three days versus 5-10 day antibiotic therapy, Outcome 14 Adverse effects requiring

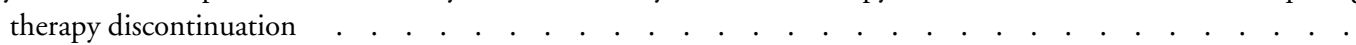

Analysis 01.15. Comparison 01 Three days versus 5-10 day antibiotic therapy, Outcome 15 Gastrointestinal adverse effects . . . . . . . . . . . . . . . . . . . . . . . . . . . . . . . . . . . . . . . . . . . . . .

Analysis 01.16. Comparison 01 Three days versus 5-10 day antibiotic therapy, Outcome 16 Skin adverse effects . . Analysis 01.17. Comparison 01 Three days versus 5-10 day antibiotic therapy, Outcome 17 CNS adverse effects . . Analysis 01.18. Comparison 01 Three days versus 5-10 day antibiotic therapy, Outcome 18 Vaginal discharge as an

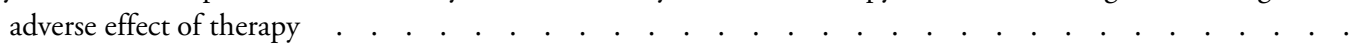
Analysis 01.19. Comparison 01 Three days versus 5-10 day antibiotic therapy, Outcome 19 Other adverse effects Analysis 01.20. Comparison 01 Three days versus 5-10 day antibiotic therapy, Outcome 20 Patients with any adverse effects during treatment by antibiotic class (same drug) 


\title{
Duration of antibacterial treatment for uncomplicated urinary tract infection in women (Review)
}

\author{
Milo G, Katchman EA, Paul M, Christiaens T, Baerheim A, Leibovici L
}

This record should be cited as:

Milo G, Katchman EA, Paul M, Christiaens T, Baerheim A, Leibovici L. Duration of antibacterial treatment for uncomplicated urinary tract infection in women. Cochrane Database of Systematic Reviews 2005, Issue 2. Art. No.: CD004682. DOI: 10.1002/14651858.CD004682.pub2.

This version first published online: 20 April 2005 in Issue 2, 2005.

Date of most recent substantive amendment: 22 February 2005

\section{A B S T R A C T}

\section{Background}

Uncomplicated urinary tract infection (UTI) is a common disease, occurring frequently in young sexually active women. In the past, seven day antibiotic therapy was recommended while the current practice is to treat uncomplicated UTI for three days.

\section{Objectives}

TO compare the efficacy and safety of three-day antibiotic therapy to multi-day therapy (five days or longer) on relief of symptoms and bacteriuria at short-term and long-term follow-up.

\section{Search strategy}

The Cochrane Library (Issue 1, 2004), the Cochrane Renal Group's Register of trials (July 2003), EMBASE (January 1980 to August 2003), and MEDLINE (January 1966 to August 2003) were searched. We scanned references of all included studies and contacted the first or corresponding author of included trials and the pharmaceutical companies.

\section{Selection criteria}

Randomised controlled trials comparing three-days oral antibiotic therapy with multi-day therapy (five days and longer) for uncomplicated cystitis in 18 to 65 years old non-pregnant women without signs of upper UTI.

\section{Data collection and analysis}

Data concerning bacteriological and symptomatic failure rates, occurrence of pyelonephritis and adverse effects were extracted independently by two reviewers. Relative risk (RR) and their $95 \%$ confidence intervals (CI) were estimated. Outcomes were also extracted by intention-to-treat analysis whenever possible.

\section{Main results}

Thirty-two trials (9605 patients) were included. For symptomatic failure rates, no difference between three-day and 5-10 day antibiotic regimen was seen short-term (RR 1.06, 95\% CI 0.88 to 1.28) and long-term follow-up (RR 1.09, 95\% CI 0.94 to 1.27). Comparison of the bacteriological failure rates showed that three-day therapy was less effective than 5-10 day therapy for the short-term followup, however this difference was observed only in the subgroup of trials that used the same antibiotic in the two treatment arms (RR $1.37,95 \%$ CI 1.07 to $1.74, \mathrm{P}=0.01$ ). This difference was more significant at long-term follow-up (RR $1.43,95 \%$ CI 1.19 to 1.73 , $\mathrm{P}=0.0002)$. Adverse effects were significantly more common in the 5-10 day treatment group (RR $0.83,95 \%$ CI 0.74 to $0.93, \mathrm{P}=$ $0.0010)$. Results were consistent for subgroup and sensitivity analyses.

\section{Authors' conclusions}

Three days of antibiotic therapy is similar to 5-10 days in achieving symptomatic cure during uncomplicated UTI treatment, while the longer treatment is more effective in obtaining bacteriological cure. In spite of the higher rate of adverse effects, treatment for 5-10 days could be considered for treatment of women in whom eradication of bacteriuria is important.

Duration of antibacterial treatment for uncomplicated urinary tract infection in women (Review)

Copyright ( 2007 The Cochrane Collaboration. Published by John Wiley \& Sons, Ltd 


\section{PLAIN LANGUAGE SUMMARY}

Uncomplicated urinary tract infection (UTI) is a common disease occurring frequently in young women. It is caused by bacteria multiplying in urine, and the patient usually complains of urgency and burning pain while urinating. The present practice is to treat the patient with antibiotics for three days. In this review we included all studies that compared three-day therapy with longer treatment (five days or more). Three days of treatment were adequate to achieve symptomatic relief for most patients, but it appears that longer therapy is better in terms of bacteria elimination from the urine, no matter what antibiotic is used. Longer therapy for UTI is related to higher rate of adverse reactions to the antibiotics used. Pending further research, it could be considered for women in whom eradication of bacteria in the urine is important.

\section{B A C K G R O U N D}

Uncomplicated urinary tract infection (UTI) is a common disease, occurring frequently in young sexually active women. In one cohort study the incidence of the disease was estimated to be 0.5 0.7/person-year (Hooton 1996). All over the world the most common pathogens of uncomplicated UTI are similar: 80-90\% Escherichia coli, 5-10\% Staphylococcus saprophyticus, the remaining infections being caused by Proteus spp., and other Gram-negative rods. Most are bacteria from the gut that colonize the perineum and then ascend through the urethra to infect the bladder mucosa. The infection causes specific symptoms, mainly the triad of dysuria (painful urination), urgency (the urgent need to void) and frequency (very frequent urination). In randomised controlled trials (RCTs) the diagnosis is based on positive urine cultures in symptomatic subjects. In the past, the threshold for diagnosis of UTI was $>10^{5}$ colony forming units $(\mathrm{CFU}) / \mathrm{ml}$ of voided midstream urine (Stamm 1982). However two decades ago studies have shown that in young symptomatic women with leucocyturia even $100 \mathrm{CFU} / \mathrm{ml}$ voided midstream urine can establish the diagnosis (Stamm 1980; Stamm 1982; Kunin 1993).

A large range of antimicrobials with different rates of cure and side effects are used in the treatment of UTI. It is thought that a shortcourse therapy consisting of a three-day antibacterial regimen is sufficient for uncomplicated urinary tract infection, as it is probably as effective as 7-10 days therapy, and may be associated with less side effects and lower costs (Hooton 1997). Single dose therapy has been advocated for years but about a decade ago reviews have raised doubts as to its use because of a higher frequency of bacteriological recurrence (Leibovici 1991; Norrby 1990), and it is no longer common clinical practice. On the other hand, singledose treatment probably achieves symptomatic relief more rapidly than seven days of treatment (Arav-Boger 1994).

In most clinical trials assessing effectiveness of therapy, cure was defined as bacteriological cure, rather than symptomatic relief. Uncomplicated UTI is not considered a serious disease. It is not clear whether untreated UTI can progress to pyelonephritis, and if so how often. Progression to pyelonephritis probably occurs at a very low rate, while asymptomatic bacteriuria in young, healthy and non-pregnant women is not associated with renal damage (Stamm 1991).

Thus since our last systematic review on the length of treatment of uncomplicated UTI in young women (Leibovici 1991), the following questions arose:

1. What is the relative effectiveness of three days treatment compared with multi-day treatment?

2. Is any difference modified by the antibiotic used (old versus new) or CFU/ml count?

3. Do persistent positive cultures lead to persistent symptoms?

4. What is the relative effectiveness of single dose and three-day treatment, compared with seven days treatment, when the outcome of interest is symptomatic cure rather than bacteriological one?

5. Does the duration of treatment influence the development of resistant strains during treatment?

\section{O B JEC T IVES}

The main objective of this review was to assess the evidence, as found in RCTs for the relative effectiveness of different regimens of antibacterial treatments in acute, uncomplicated lower urinary tract infection in otherwise healthy 16 to 65 years old females.

Specific objectives were:

1. To assess the evidence for the relative effectiveness as assessed in RCT's comparing three-day versus multi-day therapy on:

a. Relief of symptoms within two weeks after start of treatment ( mostly within seven days)

b. Resolution of bacteriuria within two weeks after start of treatment (bacteriological cure)

c. Recurrence of symptoms or bacteriuria between cure and up-to eight weeks after start of treatment

$\mathrm{d}$. To assess the frequency of adverse events in the different regimens

2. To assess the evidence for the relative effectiveness of the different antibacterial drugs used in the RCTs.

3. To assess the evidence for development of resistance for different durations of treatment with different drugs (comparing resistance of grown bacteria before and after therapy). 


\section{CRITERIA FOR CONSIDERING STUDIES FOR THIS REVIEW}

\section{Types of studies}

We attempted to identify all RCTs comparing the relative effectiveness of three day versus five days or longer oral antibacterial therapy for uncomplicated UTI in women.

\section{Types of participants}

We included studies on ambulatory, otherwise healthy women, aged 16-65 years, with uncomplicated UTI defined by the presence of urinary complaints (and by the absence of upper UTI signs); whenever possible, analysis for the review was limited to women with positive urine cultures of more than $100 \mathrm{CFU} / \mathrm{ml}$ of voided midstream urine or obtained via urinary catheter.

Uncomplicated UTI was defined as the absence of all the following:

1. Costovertebral pain or tenderness

2. Fever (more than $37.8 \mathrm{C}$ )

3. Positive blood cultures.

In addition, trials of the following groups of people were excluded from the review:

1. Multiple vomiting

2. Sepsis

3. Children up to the age of 16 years

4. Hospital acquired infection

5. Pregnancy

6. Indwelling urinary catheter

7. Recent urinary tract instrumentation

8. Known pathological, functional or anatomic abnormality of the urinary tract

9. Diabetes mellitus

10. Immunocompromised patients

\section{Types of intervention}

Three days oral antibacterial treatment versus antibacterial treatment for five days or more (antibacterial therapy given in both arms did not have to be identical).

\section{Types of outcome measures}

1. Short-term symptomatic failure, defined as persistence or recurrence of symptoms up to two weeks after starting treatment.

2. Long-term symptomatic failure, defined as persistence or recurrence of urinary symptoms up to eight weeks after start of treatment.

3. Short-term bacteriological failure, defined as a positive urine culture at the first follow-up within two weeks after start of treatment.

4. Long-term bacteriological failure, defined as a positive urine culture up to eight weeks after start of treatment.

5. Occurrence of pyelonephritis during follow-up.

6. Adverse events: a. Any serious adverse events that are fatal, life-threatening, or requiring hospitalisation;

b. Any adverse events that result in significant disability or incapacity;

c. Any important medical events that may not be immediately lifethreatening, or result in death or hospitalisation, but may jeopardize the patient or may require intervention to prevent one of the above outcomes;

d. Any adverse events that require discontinuation of medication. e. Adverse events by the involved organs: skin, gastro-intestinal, vaginal discharge, central nervous system, others.

7. The percentage of pathogens resistant to the study drug two to eight weeks after start of treatment.

\section{SEARCH METHODSFOR IDENTIFICATION OF STUDIES}

See: Cochrane Renal Group methods used in reviews.

A). The Cochrane Library (Issue 3, 2003), the Cochrane Renal Group's Register of trials (July 2003), EMBASE (January 1980 to August 2003 ), and MEDLINE (January 1966 to August 2003) were searched with the phrase:

[(urinary near infection*) or cystitis or uti] and [(treatment near duration) or (single near $\left.\mathrm{dos}^{*}\right)$ or $(3$ near day*) or (three near day $\left.\left.^{*}\right)\right]$

We included all languages. By leaving single dose in the search strategy we found articles that include single and three-day doses versus multi-day.

B). An additional search was performed in January 2004 with the assistance of the Trials Search Coordinator (see additional Table 01 - Electronic databases searched)

C). Reference searching and personal contact: The references of all identified studies were inspected for more studies. Additionally, the first or corresponding author of each included study was contacted for complementary information on his own trial as needed.

\section{METHODS OF THE REVIEW}

Two reviewers independently inspected each reference identified by the search and applied the inclusion criteria. For possible relevant articles, or in cases of disagreement between the two reviewers, the full article was obtained and inspected independently by a third reviewer.

\section{Quality assessment}

Trials fulfilling the review inclusion criteria were assessed for methodological quality by two reviewers. This was done using the criteria described in the Cochrane Handbook (Clarke 1999), based on the evidence of a strong association between poor allocation

Duration of antibacterial treatment for uncomplicated urinary tract infection in women (Review)

Copyright ( 2007 The Cochrane Collaboration. Published by John Wiley \& Sons, Ltd 
concealment and overestimation of effect (Schulz 1995) and defined as below:

\section{Allocation concealment}

A. Low risk of bias (adequate allocation concealment)

B. Moderate risk of bias (some doubt about the allocation concealment)

C. High risk of bias (inadequate allocation concealment)

For the purpose of the analyses in this review, trials were included if they meet the criteria A or B in the Handbook (Clarke 1999; Kunz 1998).

\section{Intention-to-treat (ITT) analysis}

ITT analysis was performed regarding all dropouts in study as failures to achieve symptomatic or bacteriological cure. Whenever possible, we regarded only the patients with positive urine cultures (significant bacteriuria) as the reference total patient number in the two study arms. When the numbers of randomised women with positive cultures in the study groups was unavailable, the total number of randomised patients was taken for performing the ITT analysis for symptomatic short-term and long-term failures, but not for the bacteriologic outcomes.

\section{Data collection}

Two reviewers independently extracted the data of included trials. Trials were identified by the name of the first author and year in which the trial was first published and ordered chronologically. The following data will be extracted, checked and recorded:

(i) Characteristics of trials

* Date, location, period of data collection, year of publication;

* Publication status;

* Case definitions (symptomatic, bacteriological, both)

* Bacteriologic definition $\left(10^{5}\right.$ or $\left.10^{2} \mathrm{CFU} / \mathrm{ml}\right)$

* Sponsor of trial (commercial, academic, pharmaceutical, or unknown)

* Blinding

* Allocation concealment (yes, no and method)

* Definitions of cure (symptomatic, bacteriological or both)

(ii) Characteristics of participants

* Number of participants in each group;

* Age (as described in the article: mean, median or range);

(iii) Characteristics of interventions

* Type, dose and duration of antibacterial therapy;

\section{(iv) Characteristics of outcome measures}

* No of patients with bacteriological cure (as defined above) in each group;

* No of patients with symptomatic recurrence (as defined above)

in each group, divided into local and systemic recurrences;

* No of patients with bacteriological recurrence (as defined above)

in each group;

${ }^{*}$ No of patients with adverse reactions, per type and total;

* No of patients with resistant microorganisms, as defined above;
* Lost to each follow-up (dropouts) before end of study.

Data synthesis

Dichotomous data was analysed by calculating the relative risk (RR) for each trial with the uncertainty in each result being expressed using 95\% confidence intervals (CI). Whenever comparisons made between the mean duration of symptoms in the two groups were normally distributed, these continuous data were analysed by using the mean and standard deviation of each trial and calculating the effect size (average mean difference) and the $95 \%$ CI.

\section{Heterogeneity and publication bias}

Heterogeneity in the results of the trials was initially assessed by inspection of graphical presentations and by calculating a test of heterogeneity ( $\mathrm{Chi}^{2}$ and $\mathrm{I}^{2}$ - Higgins 2003). We anticipated between-trial variation in estimation of morbidity for those patients who were treated with different antibiotics. Subgroup analyses were performed in order to assess the impact of this possible source of heterogeneity in the main results. The following factors were checked: allocation generation and concealment methods, different antibiotics groups (quinolones, beta-lactams etc), per cent of dropouts in the studies.

A funnel plot estimating the precision of trials (plots of RR for efficacy against the sample size) was examined in order to estimate potential asymmetry. A fixed effect model was used throughout the review, except in the event of significant heterogeneity between the trials $(\mathrm{P}<0.10)$, when the random effect model was chosen.

\section{DESCRIPTIONOFSTUDIES}

The computerised search strategy identified a large number of publications comparing different regimens of antibiotic therapy for UTI, not all relevant for the present review. These were screened for RCTs, uncomplicated UTIs, antibiotics treatment duration and presence of exclusion criteria. Of 56 trials obtained this way 24 were excluded for different reasons (see Table of excluded studies) while 32 RCTs were considered eligible for this review.

Two reports were identified as duplicate publications and are considered under their primary reference (Sandberg 1985). Five publications were found to be case-control or non randomised studies (Bargelloni 1972; Furusawa 1994; Hoigne 1977; Liudvig 1996; Loran 1997), while five others were reviews of different trials of which several were included in the analysis (Blomer 1986; Hooton 1989; Iravani 1991; Iravani 1995; Vogel 1984). Eight RCTs compared two different antibiotic regimens of at least five days duration (Bailey 1983; Fancourt 1984; Hill 1985; Little 1979; Martin 1983; McCarthy 1972; Pelta 1985; Zorbas 1995), two additional trials were excluded for they compared a single-dose antibiotic to ten-day (Schultz 1984) or three-day (Gellerman 1988) regimen. Another trial reported only clinical improvement but not cure (Ishihara 1998). One further study was excluded because it in- 
cluded only elderly postmenopausal women (mean age $66 \pm 20$ ) (Raz 1996). Two trials were excluded as they appeared to be quasirandomised or criterion C in the Handbook (Charlton 1976; Fair 1980).

Thirty-two trials were included in the review (see Table of included studies). One trial compared two different antibiotics with subgroups of three-day and ten-day treatment regimens in each, and the results for these two drugs were regarded separately as two different trials (Gordin 1987a; Gordin 1987b).

The contact authors of these 32 included and two excluded as quasi-RCTs (Charlton 1976; Fair 1980) were contacted (by mail and if possible by e-mail) of whom 10 replied. Unpublished data were obtained for seven studies.

\section{Patient characteristics}

The included studies were performed between the years 19802002 and included 9605 randomised patients. The median number of patients/trial was 300 .

In six trials (1356 patients) men were included (Basista 1991; Cox 1992; Hansen 1981; Menday 2000; Rapoport 1981; Stein 1987). Their number was less than $10 \%$ in each study group and it was impossible to separate the results for men and women for any of these trials. One additional trial (Bitsch 1985) included men, but analysis of men and women was separated and only data regarding women was used for this review.

Fourteen studies included women above 65 years of age (Basista 1991; Bitsch 1985; Cox 1992; Guibert 1997; Hansen 1981; Internordic 1988; Iravani 1999; Menday 2000; Piipo 1990; Rapoport 1981; Sandberg 1985; Stein 1987; Stein 1992; Tsugawa 1999). In all these 14 trials patients above 65 years made up the minority of the study groups and in 7 of these trials the mean age reported (33 to 45 years) was well below the upper limit we defined for this review (Basista 1991; Bitsch 1985; Guibert 1997; Hansen 1981; Rapoport 1981; Sandberg 1985; Stein 1992). Unfortunately, it was impossible to analyse data for patients below and above the age of 65 separately.

Nearly all trials defined bacteriuria as more than $10^{5} \mathrm{CFU} / \mathrm{ml}$ for any bacteria or the same concentration for Gram-negative bacteria and $10^{4} \mathrm{CFU} / \mathrm{ml}$ for Staphylococcus. Several studies included patients with lower urine bacteria concentration of $10^{4} \mathrm{CFU} / \mathrm{ml}$ (Hovelius 1985; Neringer 1992; Stein 1992; Tsugawa 1999), $10^{3}$ $\mathrm{CFU} / \mathrm{ml}$ (Iravani 1999) and $10^{2} \mathrm{CFU} / \mathrm{ml}$ (Hooton 1991) for any bacteria. In one trial, positive urine culture was not necessary for patient inclusion and the case definition was based on the clinical signs and pathologic urinalysis (Guibert 1997).

In two trials several women with asymptomatic bacteriuria were treated and taken into account for the bacterial cure results (Gordin 1987a; Gordin 1987b; Hooton 1991).

\section{Antibiotic regimens}

The same antibiotics in the three-day and 5-10 day groups were used in 19 trials, of these quinolones were used in six trials (Garcia 2002; Internordic 1988; Neringer 1992; Piipo 1990; Trienekens 1993; Tsugawa 1999), beta-lactams in eight (Gordin 1987b; Greenberg 1986; Hansen 1981; Hovelius 1985; Marsh 1980; Pitkajarvi 1990; Richards 1984; Sandberg 1985) and different combinations of sulfonamides and trimethoprim in five trials (Gordin 1987a; Gossius 1984; Gossius 1985; Iravani 1983; Trienekens 1989). In one of these studies different doses of the same antibiotic drug (pivmecillinam) were used in the two study groups (Hansen 1981).

Fourteen trials compared different antibiotics given in the threeday and in the 5-10 day groups. The drug in the three-day group was a quinolone in nearly all of these studies, and was compared to 5-10 day regimens of beta-lactam (Winwick 1981), different combinations of sulfonamides and trimethoprim (Basista 1991; Bitsch 1985; Butler 1983; Cox 1992; Hooton 1991; Stein 1987), another quinolone (Henry 1999; Guibert 1997; Stein 1992) or a combination of nitrofurantoin with trimethoprim-sulfamethoxazole (Iravani 1999). One additional trial compared three-day treatment with trimethoprim-sulfamethoxazole to seven-day treatment with any of a long list of antibiotics (Rapoport 1981). In two trials three-day therapy with beta-lactam was compared to seven-day treatment with another drug of the beta-lactam group (Menday 2000) or trimethoprim-sulfamethoxazole (Figueroa 1999).

\section{METHODOLOGICALQUALITY}

\section{Randomisation and allocation concealment}

Adequate allocation concealment, using sealed envelopes or central randomisation, was described in 12 trials (Basista 1991; Bitsch 1985; Gordin 1987a; Gordin 1987b; Henry 1999; Hooton 1991; Hovelius 1985; Iravani 1999; Neringer 1992; Piipo 1990; Richards 1984; Sandberg 1985; Trienekens 1993). Allocation generation was adequate in all 12 and in additional six (Butler 1983; Gossius 1985; Marsh 1980; Pitkajarvi 1990; Stein 1987; Stein 1992). These studies used computer-generated lists or predetermined randomised codes. Randomisation methods were not described in all other trials.

\section{Blinding}

Ten trials were double-blinded (Henry 1999; Internordic 1988; Iravani 1999; Menday 2000; Neringer 1992; Piipo 1990; Stein 1992; Trienekens 1989; Trienekens 1993; Tsugawa 1999), one single-blinded (Richards 1984) and the remaining open RCTs.

\section{ITT analysis}

ITT analysis was presented in only two of the 32 trials included for treatment failure (Henry 1999; Iravani 1999). Dropouts and numbers of patients with positive urine cultures were reported by their allocation group in 21 of 32 trials presenting per protocol analysis for treatment failure, permitting a second ITT analysis 
assuming dropouts as failures. The number of patients excluded from the analysis at the first follow-up ranged between $0-20 \%$ for bacteriological cure outcome and $0-26 \%$ for clinical (symptomatic) cure; at the second follow-up these numbers were $0-29 \%$ and $6-45 \%$, respectively.

The first follow-up was performed between two to 15 days from the end of the treatment (short-term), and the second follow-up was performed four to 10 weeks from the treatment (long-term).

\section{R E S U L T S}

Trials were divided into two major subgroups: those with the same antibiotics in the two allocation groups and those with different drugs.

\section{Effectiveness \\ Symptomatic failure \\ Short-term}

Assessment of short-term symptomatic failure rate was possible in 24 trials (8752 patients). Data for efficacy analysis was available in 5165 patients. No significant difference between three-day and 510 day antibiotic treatment was observed (outcome 01: RR 1.06, $95 \%$ CI 0.0 .88 to $1.28, \mathrm{P}=0.52$ ), with no significant heterogeneity observed for this comparison $\left(\mathrm{Chi}^{2}=27.14, \mathrm{df}=23, \mathrm{P}=0.25, \mathrm{I}^{2}\right.$ $=15.3 \%)$

Separate analysis of trials with same or different antibiotic in the two treatment arms showed no significant difference. In 14 trials comparing the same antibiotic the RR was 1.15 (95\% CI 0.95 to 1.39 , outcome 01.01$)$ in 10 trials with different antibiotics the RR was 0.90 (95\% CI 0.62 to 1.29 , outcome 01.02). No differences were shown after performing subgroup analyses for the factors: antibiotic classes (quinolones, beta-lactams, sulfonylamides with or without trimethoprim); allocation generation and concealment; or per cent of dropouts.

\section{Long-term}

Assessment of long-term symptomatic failure rate was available from eight trials (3141 patients). No difference was found between the two arms (outcome 03: RR 1.09, 95\% CI 0.94 to 1.27). After performing subgroup analysis as for the first follow-up results no differences were shown.

A secondary ITT analysis counting dropouts as failures of treatment showed similar results (outcomes 02 and 04).

\section{Bacteriologic failure}

Short-term

Assessment of short-term bacteriological failure rate was possible in 31 trials (8874 patients). For efficacy analysis 5368 patients were included, the majority of the excluded persons having negative urine cultures after being allocated to one of the study regimens. Five to 10-day antibiotic regimen appeared to be superior to the three-day regimen although the result was not significant using the random effects model (outcome 05: RR 1.19, 95\% CI 0.98 to $1.44, \mathrm{P}=0.08$ ), but just significant with the fixed effect model (RR 1.20, 95\% CI 1.00 to $1.44, \mathrm{P}=0.05$ ). No significant heterogeneity was observed for this comparison $\left(\mathrm{Chi}^{2}=24.54\right.$, $\left.\mathrm{df}=29, \mathrm{P}=0.70, \mathrm{I}^{2}=0 \%\right)$. This advantage was observed in trials comparing the same antibiotic (outcome 05.01: RR 1.37, 95\% CI 1.07 to $1.74 ; \mathrm{P}=0.01$ ), and absent in the subgroup analysis of trials comparing different drugs (RR $0.96,95 \%$ CI 00.68 to 1.35 , P $=0.80$ ). The trials using same antibiotic drug in the two treatment arms was further divided for subgroup analysis based on the different antibiotic classes (outcome 06) and showed that the results were not significantly influenced by the drug choice. The results remain unchanged after performing the other subgroup analyses (for allocation generation and concealment class, trial size or per cent of dropouts).

A secondary ITT analysis for the short-term results was only possible in 21/31 trials. Its results showed actually no difference between the two treatment regimens, (outcome 07: RR 0.92, 95\% CI 0.80 to 1.06). No difference was observed in any of the subgroups analyses.

\section{Long-term}

Assessment of the long-term bacteriological failure rate was possible in 18 trials ( 3715 patients) (13 trials and 2502 patients in the same antibiotic subgroup; five trials and 1213 patients in the different regimens subgroup). The 5-10-day antibiotic regimen was superior to the three-day regimen (outcome 08: RR 1.31, 95\% CI 1.08 to $1.60, \mathrm{P}=0.006)$ and no significant heterogeneity was observed $\left(\mathrm{Chi}^{2}=24.40, \mathrm{df}=17, \mathrm{P}=0.11, \mathrm{I}^{2}=30.3 \%\right)$. A significant difference was shown in the subgroup of trials with the same drug in both allocation arms (outcome 08.01: RR 1.43, 95\% CI 1.19 to $1.73, \mathrm{P}=0.0002$ ), while no difference was observed between 5-10 day and three day regimens when different drugs were used. These results also remain unchanged after performing the additional subgroup analyses for antibiotic class (outcome 09), allocation generation, trial size and concealment class or per cent of dropouts.

A secondary ITT analysis for the second follow-up results showed the same results as the efficacy analysis, confirming the observed significant advantage of 5-10 day antibiotic regimen over the threeday regimen for all trials (outcome 10: RR 1.19, 95\% CI 1.06 to $1.35, \mathrm{P}=0.004)$, and for the subgroup of the same drug regimen (outcome 10.01: RR 1.26, 95\% CI 1.08 to $1.47, \mathrm{P}=0.003$ ). The results of the subgroup analysis for the class of antibiotic drug are shown in outcome 11 .

\section{Pyelonephritis}

Only five of the included trials reported the incidence of pyelonephritis (Cox 1992; Gossius 1984; Gossius 1985; Hovelius 1985; Winwick 1981). Only two cases of pyelonephritis were reported, both in the three-days therapy groups (Gossius 1984; Gossius 1985). As this outcome was extremely uncommon in the population of young women with uncomplicated lower UTI, no dif- 
ference could be observed between the two treatment regimens (outcome 13).

\section{Adverse effects}

All side effects were observed more frequently in the 5-10 day regimen than in the three-day group. The risk for the development of any side effect during therapy was $17 \%$ lower in the threeday group (outcome 12: RR $0.83,95 \%$ CI 0.74 to $0.93, \mathrm{P}=$ 0.0010). This difference was more prominent in trials comparing the same antibiotic (outcome 12.01: RR 0.76, 95\% CI 0.63 to 0.92 ) and especially when the drug was sulfonylamide/trimethoprim (outcome 20: RR 0.40, 95\% CI 0.19 to 0.88 ).

A substantially lower percentage of patients had to discontinue therapy in the three-day group, (outcome 14: RR 0.51, 95\% CI 0.328 to $0.91, \mathrm{P}=0.02$ ), particularly when the same drug was given in the two groups (outcome 14.01: RR 0.35, 95\% CI 0.12 to $0.98, \mathrm{P}=0.04)$.

Gastrointestinal side effects appeared less frequently during threeday treatment (outcome 15: RR 0.81, 95\% CI 0.67 to $0.94, \mathrm{P}$ $=0.02$ ). The difference in the frequency of development a skin rash was significant in the trials comparing the same antibiotic (outcome 16.01: RR 0.51,95\% CI 0.33 to $0.77, \mathrm{P}=0.002$ ), while no such difference was observed in the trials with different drugs (outcome 16.02: RR 0.69, 95\% CI 0.21 to 2.28). The rate of side effects related to central nervous system was also slightly more frequent in the 5-10 day group, but this difference was not significant overall (outcome 17: RR 0.83, 95\% CI 0.65 to $1.06, \mathrm{P}=0.13$ ).

As for anaphylactic reactions, only two trials described one case, both in the 5-10 day group (Butler 1983; Gossius 1984), and no difference could be observed between the two treatment regimens.

\section{Resistant organisms}

Only a minority of the included trials described the antibiotic resistance profile of the bacteria cultured from patients urine before and after treatment. In two studies using quinolones in both treatment arms, no persistent or recurrent pathogen developed resistance to the study drugs during treatment or during the followup period (Internordic 1988; Neringer 1992). In one trial studying thee-day versus seven-day pivmecillinam regimens (Richards 1984) the number of resistant bacteria isolates after therapy did not change, and an additional trial using the same drug (Hansen 1981) showed only total rate of resistance development after therapy without specification to different study groups. Two studies using sulfonamide (Iravani 1983) and co-trimoxazole (Trienekens 1989) mentioned the prevalence of the drug-resistant E. coli in the failure cases, but it was unclear whether these were primary resistant strains or the resistance developed during the treatment. One study (Basista 1991) showed significant difference in the development of urine bacteria resistance between the three-day (no cases) and the seven-day (three cases) protocols but the drugs used in the two treatment arms were different (quinolone versus trimetho$\mathrm{prim} / \mathrm{sulfamethoxazole),} \mathrm{so} \mathrm{this} \mathrm{data} \mathrm{is} \mathrm{of} \mathrm{only} \mathrm{limited} \mathrm{value.}$

\section{Dropouts and selection bias}

Funnel plots for symptomatic (Figure 01 - Funnel plot symptomatic failure) and bacteriological failure (Figure 02 - Funnel plot bacteriologic failure ) showed that several smaller studies favouring the three-day regimen may be missing from this review. It is important to mention that all the studies included in this meta-analysis were planned to check the hypothesis that the three-day antibiotic therapy is as effective as a longer one.

The number of patients excluded from each study arm was nearly equal, both for symptomatic and bacteriological outcomes assessment.

\section{DISCUSSION}

Thirty-two RCTs, including 9605 patients, comparing three-day antibiotic treatment to 5-10 day treatment for the empirical therapy of uncomplicated UTIs in the young and middle-aged women were analysed. Two outcomes were chosen for comparison: symptomatic failure and bacteriological failure as defined by positive post-treatment urine cultures. Primary treatment failures and recurrences or re-infections were considered together as therapy failures, for in the majority of the studies no distinction could be made between them.

Symptomatic failure rates did not differ significantly both in the short-term (RR $1.06,95 \%$ CI 0.88 to 1.28 ) or long-term (RR $1.07,95 \%$ CI 0.99 to 1.16 ) after treatment with three-day or 5 10 day regimens. No information about the timing of the symptomatic cure could be found in the included studies.

Five to 10 day antibiotic regimen was more effective than three day therapy, keeping the patients' urine sterile two to 15 days after the end of treatment (same drug therapy RR 1.37, 95\% CI 1.07 to $1.74, \mathrm{P}=0.01$ ). This means that 41 women would have to be treated for seven days to prevent one case of recurrence or persistence of bacteriuria for a short period. The ITT analysis showed no difference between short and long treatment regimens. Data considering the numbers of randomised patients with positive urine cultures were unattainable from the published articles or any additional source in six major studies in this subgroup (Garcia 2002; Gossius 1984; Gossius 1985; Marsh 1980; Richards 1984; Trienekens 1993), so it was impossible to include these trials into the ITT analysis. This fact, together with the high rate of dropouts, could explain why we failed to show a significant effect of therapy duration on the short-term bacteriologic failure rates in the ITT analysis.

A larger advantage of 5-10 day over three-day antibiotic therapy in preventing bacteriological failure was observed after 4-10 weeks (RR $1.43,95 \%$ CI 1.19 to $1.73, \mathrm{P}=0.0002$ ) when treatment with the same drug was compared (number needed to treat $(\mathrm{NNT})=4$ ). This difference remained significant also with an ITT analysis (RR $1.26,95 \%$ CI 1.08 to $1.47, \mathrm{P}=0.003)$. It is important to mention 
that the advantage of the longer therapy in terms of bacteriological success appeared to be independent of the antibiotic class chosen for UTI treatment including quinolones.

One reason for the advantage of longer therapy might be the survival of bacteria in subepithelial loci of the lower urinary tract after a shorter course of antibiotic treatment. Recently the ability of E. coli to invade epithelial cells and create biofilms with pod-like bulges on the bladder surface was discovered (Anderson 2003). These pods contain bacteria encased in a polysacchariderich matrix surrounded by a protective shell of uroplakin, and allow bladder infections to persist in the face of robust host defences and short-term antibiotic treatment. Another recently published study showed that asymptomatic bacteriuria is associated with an increased risk of symptomatic UTI in young women (Hooton 2000). Thus, bacteriological failure might also carry a clinical significance for the patients.

The probable cause for the absence of such difference in the trials comparing different drugs in the two study groups was the fact that all but three of these trials compared three-day quinolone therapy with 5-10 day regimen of beta-lactams or sulfonylamides/ trimethoprim. Both the higher urine concentration and the lower rate of bacteria drug resistance favoured the newer quinolones. When trying to answer the question concerning the optimal treatment duration for UTI one should probably consider trials comparing the same drug in the two therapy groups.

We found a discrepancy between symptomatic cure, which was not influenced by treatment duration, and bacteriological cure. Fewer included trials showed results of symptomatic cure as compared to bacteriologic results (21 versus 31 studies at the first followup and 10 versus 18 at the second follow-up, respectively). This could be one of the reasons explaining the discrepancy between the efficacy results for these two outcomes.

Not surprisingly, the cost of the higher bacteriological cure rates after longer antibiotic therapy is a significantly higher rate of adverse events, including those leading to treatment discontinuation. Again, the difference was observed in the trials dealing with two regimens of the same drug. The per cent of patients who stopped the treatment because of adverse effects in the three-day group was $1.5 \%$ compared to $3.2 \%$ in the $5-10$ day group (RR $0.35,95 \% \mathrm{CI}$ 0.12 to $0.98, \mathrm{P}=0.04$ ), number needed to harm $=79$. However all adverse effects were minor.

We performed sensitivity analyses that did not detect sources of bias originating in studies'design, methodology or class of antibiotic drug used. However, allocation concealment was known to be adequate in only 12 of included 31 trials, and only 11 were blinded. All but two of the included studies did not adhere to the principle of ITT analysis. Larger numbers of patients excluded from the efficacy analysis was due to negative urine cultures after admission, which should be considered as exclusions rather than dropouts, but the high rate of dropouts during the follow-up was a major problem in many included studies.

\section{A U THORS' CONCLUSIONS}

\section{Implications for practice}

The present practice of treating uncomplicated UTIs in young women for only three days to achieve symptomatic relief is probably sufficient for the majority of patients. However it leaves a significant risk of recurrent or persistent bacteriuria independent of the class of the drug.

Pending further research, antibiotic treatment for 5-10 days could be considered for women in whom bacteriological eradication might be of importance: e.g. women suffering from recurrent and painful lower UTIs, planning pregnancy or with underlying disorders. Ultimately the decision regarding therapy duration should be taken with the patient, balancing the higher bacteriological cure rate versus the similar symptomatic outcome and increased risk for adverse events.

The risk of pyelonephritis development as a function of therapy duration is probably irrelevant as it is an extremely rare event in patients with lower UTI.

\section{Implications for research}

We propose that future research in this area should address the question of the link between the bacteriuria and symptomatic UTIs. Future trials should use the same antibiotic drug in the different treatment duration groups to exclude the effect of antibiotic efficacy. It is important to perform antibiotic susceptibility tests during the follow-up to assess whether duration of the antibiotic therapy influences the rate of resistance development.

The duration of treatment in special groups of women (i.e. those suffering from recurrent and painful lower UTIs, planning pregnancy, or with underlying disorders) should be addressed in further studies.

\section{POTENTIAL CONFLICTOF INTEREST}

None known.

\section{ACKNOW LEDGEMENTS}

We would like to thank Dr. Alexey G. Dolinin of the Lund University Hospital, Sweden for his help in translating several articles for this review. We would also like to thank Dr Karla Soares-Weiser who assisted the authors with the drafting of the protocol. 


\section{SOURCES OF SUPPORT}

\section{External sources of support}

- No sources of support supplied

Internal sources of support

- No sources of support supplied

\section{R E F E R E N C E S}

\section{References to studies included in this review \\ Basista 1991 \{published data only\}}

Basista MP. Randomized study to evaluate efficacy and safety of ofloxacin vs. trimethoprim and sulfamethoxazole in treatment of uncomplicated urinary tract infection. Urology 1991;37(3 Suppl):21-7. [MedLine: 2003341].

Bitsch 1985 \{published data only\}

Bitsch M, Hansen PH, Pagh J. Treatment of acute urinary infections. Comparison between pivmecillinam for 3 days and sulfamethizole therapy for 6 days. Ugeskrift for Laeger 1985;147(17):1392-5. [MedLine: 4002410].

Butler 1983 \{published data only\}

Butler AV, Cullen MJ, Parry MO, Sylvester DG, Speller DC. Acute cystitis in young women. Treatment with citrated nalidixic acid compared with co-trimoxazole. Practitioner 1983;227(1379):833-5. [MedLine: 6604266].

Cox 1992 \{published data only\}

Cox CE, Serfer HS, Mena HR, Briefer C, Childs SJ, Gordon SF, et al. Ofloxacin versus trimethoprim/sulfamethoxazole in the treatment of uncomplicated urinary tract infection. Clinical Therapeutics 1992; 14(3):446-57. [MedLine: 1638586].

Figueroa 1999 \{published data only\}

Figueroa-Damian R, Arredondo-Garcia JL. Comparison of the clinical and microbiologic efficacy of single-dose ceftibuten, 3-dose ceftibuten, and 7-day trimethoprim/sulfamethoxazole in the treatment of uncomplicated cystitis. Current Therapeutic Research, Clinical \& Experimental 1999;60(7):371-8.

Garcia 2002 \{published data only\}

Garcia Bernal G, Fava Aixendri E, Rubio Carque V, Luna Jarque J. Urinary infections without complications: comparison of a treatment with norfloxacin for 7 days versus norfloxacin for 3 days [Infecciones urinarias no complicadas: comparacion de una pauta con norfloxacino durante 7 dias frente a norfloxacino durante 3 dias]. Atencion Primaria 2002;29(1):62-3. [MedLine: 11820968].

Gordin 1987a \{published data only\}

Gordin A, Kalima S, Makela P, Antikainen R. Comparison of threeand ten-day regimens with a sulfadiazine- trimethoprim combination and pivmecillinam in acute lower urinary tract infections. Scandinavian Journal of Infectious Diseases 1987;19(1):97-102. [MedLine: 3563430].

Gordin 1987b \{published data only\} Gordin A, Kalima S, Makela P, Antikainen R. Comparison of threeand ten-day regimens with a sulfadiazine- trimethoprim combination and pivmecillinam in acute lower urinary tract infections. Scandinavian Journal of Infectious Diseases 1987;19(1):97-102. [MedLine: 3563430].

Gossius 1984 \{published data only\}

Gossius G, Vorland L. A randomised comparison of single-dose vs. three-day and ten-day therapy with trimethoprim-sulfamethoxazole for acute cystitis in women. Scandinavian Journal of Infectious Diseases 1984;16(4):373-9. [MedLine: 6396834].

Gossius G, Vorland L. Treatment of acute cystitis in women. Singledose versus a 3-day and 10-day therapeutic regimen with trimethoprim-sulfamethoxazole. Tidsskrift for Den Norske Laegeforening 1986; 106(16):1395-8. [MedLine: 3529490].

Gossius 1985 \{published data only\}

Gossius G, Vorland L. The treatment of acute dysuria-frequency syndrome in adult women: Double-blind, randomized comparison of three-day vs ten-day trimethoprim therapy. Current Therapeutic Research, Clinical \& Experimental 1985;37(1):34-42.

Greenberg 1986 \{published data only\} Greenberg RN, Reilly PM, Luppen KL, Weinandt WJ, Ellington LL, Bollinger MR. Randomized study of single-dose, three-day, and seven-day treatment of cystitis in women. Journal of Infectious Diseases 1986;153(2):277-82. [MedLine: 3484773].

Guibert 1997 \{published data only\}

Guibert J, Herman H, Capron MH. Treatment of uncomplicated recurrent cystitis in women: lomefloxacin versus norfloxacin. Fertilite Contraception Sexualite 1997;25(1):79-84. [MedLine: 9064058].

Hansen 1981 \{published data only\} Hansen PH, Kristensen KH, Lenler-Eriksen HA, Pagh J, Ostergard JE. Pivmecillinam (Selexid) in acute cystitis. A comparative study of 3- and 7-day treatments. Ugeskrift for Laeger 1981;143(11):670-3. [MedLine: 6269263].

Henry 1999 \{published data only\} Henry DC, Nenad RC, Iravani A, Tice AD, Mansfield DL, Magner DJ, et al. Comparison of sparfloxacin and ciprofloxacin in the treatment of community-acquired acute uncomplicated urinary tract infection in women. Sparfloxacin Multicenter Uncomplicated Urinary Tract Infection Study Group. Clinical Therapeutics 1999;21(6): 966-81. [MedLine: 10440621].

Hooton 1991 \{published data only\}

Hooton TM, Johnson C, Winter C, Kuwamura L, Rogers ME, Roberts PL, et al. Single-dose and three-day regimens of ofloxacin versus trimethoprim- sulfamethoxazole for acute cystitis in women. 
Antimicrobial Agents \& Chemotherapy 1991;35(7):1479-83. [MedLine: 1929311].

Hovelius 1985 \{published data only\}

Hovelius B, Mardh PA, Nygaard-Pedersen L, Wathne B. Nalidixic acid and pivmecillinam for treatment of acute lower urinary tract infections. Scandinavian Journal of Primary Health Care 1985;3(4): 227-32. [MedLine: 4081404].

Internordic 1988 \{published data only\}

Anonymous. Double-blind comparison of 3-day versus 7-day treatment with norfloxacin in symptomatic urinary tract infections. The Inter-Nordic Urinary Tract Infection Study Group. Scandinavian Journal of Infectious Diseases 1988;20(6):619-24. [MedLine: 2906171].

Iravani 1983 \{published data only\}

Iravani A, Pryor ND, Richard GA. Treatment of urinary tract infections with varying regimens of sulfisoxazole. Journal of Urology 1983; 130(3):484-7. [MedLine: 6887360].

Iravani 1999 \{published data only\} Iravani A, Klimberg I, Briefer C, Munera C, Kowalsky SF, Echols RM. A trial comparing low-dose, short-course ciprofloxacin and standard 7 day therapy with co-trimoxazole or nitrofurantoin in the treatment of uncomplicated urinary tract infection. Journal of Antimicrobial Chemotherapy 1999;43 Suppl A:67-75. [MedLine: 10225575].

Marsh 1980 \{published data only\}

Marsh BT, Menday AP. Comparative efficacy of 3-day and 7-day chemotherapy with pivmecillinam in urinary tract infections in general practice. Journal of International Medical Research 1980;8(2):105-11. [MedLine: 6245976].

Menday 2000 \{published data only\} Menday AP. Comparison of pivmecillinam and cephalexin in acute uncomplicated urinary tract infection. International Journal of Antimicrobial Agents 2000;13(3):183-7. [MedLine: 10724022].

Neringer 1992 \{published data only\}

Neringer R, Forsgren A, Hansson C, Ode B. Lomefloxacin versus norfloxacin in the treatment of uncomplicated urinary tract infections: three-day versus seven-day treatment. The South Swedish Lolex Study Group. Scandinavian Journal of Infectious Diseases 1992;24(6): 773-80. [MedLine: 1337623].

Piipo 1990 \{published data only\}

Piipo T, Pitkajarvi T, Salo SA. Three-day versus seven-day treatment with norfloxacin in acute cystitis. Current Therapeutic Research, Clinical \& Experimental 1990;47(4):644-53.

Pitkajarvi 1990 \{published data only\}

Pitkajarvi T, Pyykonen ML, Kannisto K, Piippo T, Viita P. Pivmecillinam treatment in acute cystitis. Three versus seven days study. Arzneimittel-Forschung 1990;40(10):1156-8. [MedLine: 2291755].

Rapoport 1981 \{published data only\}

Rapoport J, Rees GA, Willmott NJ, Slack RC, O'Grady FW. Treatment of acute urinary tract infection with three doses of co-trimoxazole. British Medical Journal Clinical Research Ed 1981;283(6302): 1302-3. [MedLine: 6794832].

Richards 1984 \{published data only\} Richards HH. Comparative efficacy of 3-day and 7-day chemotherapy with twice-daily pivmecillinam in urinary tract infections seen in general practice. Current Medical Research \& Opinion 1984;9(3): 197-203. [MedLine: 6499513].

Sandberg 1985 \{published data only\}

Henning C, Iwarson S, Paulsen O, Sandberg T. Cefadroxil singledose long and short therapy versus amoxicillin in female urinary tract infections. Journal of Antimicrobial Chemotherapy 1982;10 Suppl B: 73-6. [MedLine: 7142097].

* Sandberg T, Henning C, Iwarson S, Paulsen O. Cefadroxil once daily for three or seven days versus amoxycillin for seven days in uncomplicated urinary tract infections in women. Scandinavian Journal of Infectious Diseases 1985;17(1):83-7. [MedLine: 3887560].

Stein 1987 \{published data only\}

Stein GE, Mummaw N, Goldstein EJ, Boyko EJ, Reller LB, Kurtz TO, et al. A multicenter comparative trial of three-day norfloxacin vs ten-day sulfamethoxazole and trimethoprim for the treatment of uncomplicated urinary tract infections. Archives of Internal Medicine 1987;147(10):1760-2. [MedLine: 3310941].

Stein 1992 \{published data only\}

Stein GE, Philip E. Comparison of three-day temafloxacin with seven-day ciprofloxacin treatment of urinary tract infections in women. Journal of Family Practice 1992;34(2):180-4. [MedLine: 1310715].

Trienekens 1989 \{published data only\} Trienekens TA, Stobberingh EE, Winkens RA, Houben AW. Different lengths of treatment with co-trimoxazole for acute uncomplicated urinary tract infections in women. BMJ 1989;299(6711):1319-22. [MedLine: 2513939].

Trienekens 1993 \{published data only\} Trienekens TA, London NH, Houben AW, De Jong RA, Stobberingh EE. Treating acute urinary tract infections. An RCT of 3-day versus 7-day norfloxacin. Canadian Family Physician 1993;39:5148. [MedLine: 8471899].

Tsugawa 1999 \{published data only\} Tsugawa M, Nasu Y, Kumon H, Ohmori H, Nanba K, Kondo K, et al. Comparative study on 3-day and 7-day treatment with gatifloxacin in acute uncomplicated cystitis. Japanese Journal of Chemotherapy 1999; 47(11):772-85.

Winwick 1981 \{published data only\}

Winwick JG, Savage SJ. A comparison of a 3-day course of Mictral with a 7-day course of ampicillin in the treatment of urinary tract infection. Journal of International Medical Research 1981;9(1):58-61. [MedLine: 7202832].

\section{References to studies excluded from this review \\ Bailey 1983}

Bailey RR, Bishop V, Peddie B, Chambers PF, Davies PR, Crofts HG. Comparison of augmentin with co-trimoxazole for treatment of uncomplicated urinary tract infections. New Zealand Medical Journal 1983;96(744):970-2. [MedLine: 6605501].

Bargelloni 1972

Bargelloni U. New treatment of acute urinary tract infections. Minerva Urologica 1972;24(4):140-4. [MedLine: 4614053].

\section{Blomer 1986}

Blomer R, Bruch K, Zahlten RN. Summarized results of clinical phase II and III studies with ofloxacin (HOE 280) in Europe. Infection 1986;14 Suppl 1:102-7. [MedLine: 3514468]. 


\section{Charlton 1976}

Charlton CA, Crowther A, Davies JG, Dynes J, Haward MW, Mann PG, et al. Three-day and ten-day chemotherapy for urinary tract infections in general practice. British Medical Journal 1976;1(6002): 124-6. [MedLine: 764915].

\section{Fair 1980}

Fair WR, Crane DB, Peterson LJ, Dahmer C, Tague B, Amos W. Three-day treatment of urinary tract infections. Journal of Urology 1980;123(5):717-21. [MedLine: 7420563].

\section{Fancourt 1984}

Fancourt GJ, Matts SG, Mitchell CJ. Augmentin (amoxycillin-clavulanic acid) compared with co-trimoxazole in urinary tract infections. British Medical Journal Clinical Research Ed 1984;289(6437):82-3. [MedLine: 6428687].

\section{Furusawa 1994}

Furusawa T, Hiratake Y, Mishina T, Ooe H, Maegawa M, Furudama $\mathrm{H}$, et al. Evaluation of clinical efficacy and safety of cefpodoxime proxetil (CPDX-PR) in acute uncomplicated cystitis. Hinyokika Kiyo - Acta Urologica Japonica 1994;40(9):853-60. [MedLine: 7801852].

\section{Gellerman 1988}

Gellermann HJ, Grote J, Peters-Haertel W, Verbeek H. Short-term therapy with ciprofloxacin of uncomplicated infections of the urinary tract in female patients [Kurzzeit-Therapie von unkomplizierten Harnwegsinfektionen der Frau mit Ciprofloxacin]. Medizinische Welt 1988;39(51-52):1586-91.

\section{Hill 1985}

Hill S, Yeates M, Pathy J, Morgan JR. A controlled trial of norfloxacin and amoxycillin in the treatment of uncomplicated urinary tract infection in the elderly. Journal of Antimicrobial Chemotherapy 1985; 15(4):505-6. [MedLine: 3159711].

Hoigne 1977

Hoigne R, Sturm H, Fahrer H, Spiess J, Patrizzi R. Choice of the therapeutic schedule of cotrimoxazole in urinary tract infections; comparison of the effect with this of trimethoprim alone (author's transl). Schweizerische Rundschau fur Medizin Praxis 1977;66(4): 111-6. [MedLine: 319450].

\section{Hooton 1989}

Hooton TM, Latham RH, Wong ES, Johnson C, Roberts PL, Stamm WE. Ofloxacin versus trimethoprim-sulfamethoxazole for treatment of acute cystitis. Antimicrobial Agents \& Chemotherapy 1989;33(8): 1308-12. [MedLine: 2802557].

Iravani 1991

Iravani A. Treatment of uncomplicated urinary tract infections with temafloxacin. American Journal of Medicine 1991;91(6A):124-8. [MedLine: 1662882].

\section{Iravani 1995}

Iravani A, Tice AD, McCarty J, Sikes DH, Nolen T, Gallis HA, et al. Short-course ciprofloxacin treatment of acute uncomplicated urinary tract infection in women. The minimum effective dose. The Urinary Tract Infection Study Group [corrected] [see comment] [erratum appears in Arch Intern Med 1995 Apr 24;155(8):871]. Archives of Internal Medicine 1995;155(5):485-94. [MedLine: 7864704].

\section{Ishihara 1998}

Ishihara S, Ban Y, Kawada Y, Ito S, Ito Y, Doi T, et al. Fleroxacin treatment for acute uncomplicated cystitis in women: comparison of 3-day and 7-day therapy. Hinyokika Kiyo - Acta Urologica Japonica 1998;44(6):431-6. [MedLine: 9719946].

Little 1979

Little PJ, Peddie BA, Sincock A. The treatment of symptomatic urinary tract infection. Australian Family Physician 1979;8(8):895-7. [MedLine: 394732].

\section{Liudvig 1996}

Liudvig G. Clinical experience with the use of ofloxacin in infections of the upper and lower urinary tracts: demonstrations of the results of clinical trials. Antibiotiki i Khimioterapiia 1996;41(9):84-5. [MedLine: 9005795].

Loran 1997

Loran OB, Pushkar DU, Tevlin KP. Experience with the use of ciprofloxacin in patients with acute uncomplicated cystitis. Antibiotiki i Khimioterapiia 1997;42(6):42-4. [MedLine: 9313060].

\section{Martin 1983}

Martin AJ, Lacey RW. A blind comparison of the efficacy and incidence of unwanted effects of trimethoprim and co-trimoxazole in the treatment of acute infection of the urinary tract in general practice. British Journal of Clinical Practice 1983;37(3):105-11, inside back cover. [MedLine: 6603859].

McCarthy 1972

McCarthy CG. Clinical study new short acting sulfanilamide (sulfacytine). Protocol 636-48. Rocky Mountain Medical Journal 1972;69(5):45-8. [MedLine: 4556218]

Pelta 1985

Pelta DE, Bowring AR. Management of the urethral syndrome in general practice. Practitioner 1985;229(1399):47-9. [MedLine: 3887354]

\section{Raz 1996}

Raz R, Rozenfeld S. 3-day course of ofloxacin versus cefalexin in the treatment of urinary tract infections in postmenopausal women. Antimicrobial Agents \& Chemotherapy 1996;40(9):2200-1. [MedLine: 8878607].

\section{Schultz 1984}

Schultz HJ, McCaffrey LA, Keys TF, Nobrega FT. Acute cystitis: a prospective study of laboratory tests and duration of therapy. Mayo Clinic Proceedings 1984;59(6):391-7. [MedLine: 6427533].

\section{Vogel 1984}

Vogel R, Deaney NB, Round EM, VandenBurg MJ, Currie WJ. Norfloxacin, amoxycillin, cotrimoxazole and nalidixic acid. A summary of 3-day and 7-day therapy studies in the treatment of urinary tract infections. Journal of Antimicrobial Chemotherapy 1984;13 Suppl B: 113-20. [MedLine: 6234271].

\section{Zorbas 1995}

Zorbas P, Giamarellou H, Staszewska Pistoni M, Petrikkos G, Grammatikou M, et al. Comparison of 2 oral ofloxacin regimens for the treatment of bacteriuria in elderly subjects. Drugs 1995;49 Suppl 2: 384-6. [MedLine: 8549370].

\section{Additional references}

Anderson 2003

Anderson GG, Palermo JJ, Schilling JD, Roth R, Heuser J, Hultgren SJ. Intracellular bacterial biofilm-like pods in urinary tract infections. Science 2003;301(5629):105-7. [MedLine: 12843396]. 


\section{Arav-Boger 1994}

Arav-Boger R, Leibovici L, Danon YL. Urinary tract infections with low and high colony counts in young women. Spontaneous remission and single-dose vs multiple-day treatment. Archives of Internal Medicine 1994;154(3):300-4. [MedLine: 8297196].

\section{Clarke 1999}

Clarke M, Oxman AD, editors. The Cochrane Reviewers' Handbook. 4.0. The Cochrane Collaboration, 1999.

\section{Higgins 2003}

Higgins JP, Thompson SG, Deeks JJ, Altman DG. Measuring inconsistency in meta-analyses. BMJ 2003;327(7414):557-60. [MedLine: 12958120].

\section{Hooton 1996}

Hooton TM. A prospective study of risk factors for symptomatic urinary tract infection in young women. New England Journal of Medicine 1996;335(7):468-74. [MedLine: 8672152].

\section{Hooton 1997}

Hooton TM, Stamm WE. Diagnosis and treatment of uncomplicated urinary tract infection. Infectious Disease Clinics of North America 1997;11(3):551-81. [MedLine: 9378923].

\section{Hooton 2000}

Hooton TM, Scholes D, Stapleton AE, Roberts PL, Winter C, Gupta $\mathrm{K}$, et al. A prospective study of asymptomatic bacteriuria in sexually active young women. New England Journal of Medicine 2000;343 (14):992-7. [MedLine: 11018165].

\section{Kunin 1993}

Kunin CM, White LV, Hua TH. A reassessment of the importance of "low-count" bacteriuria in young women with acute urinary symptoms. Annals of Internal Medicine 1993;119(6):454-60. [MedLine: 8357110].

\section{Kunz 1998}

Kunz R, Oxman AD. The unpredictability paradox: review of empirical comparisons of randomised and non-randomised clinical trials. BMJ 1998;317(7167):1185-90. [MedLine: 9794851].

\section{Leibovici 1991}

Leibovici L, Wysenbeek AJ. Single-dose antibiotic treatment for symptomatic urinary tract infections in women: a meta-analysis of randomized trials. Quarterly Journal of Medicine 1991;78(285):4357. [MedLine: 1670063].

\section{Norrby 1990}

Norrby SR. Short-term treatment of uncomplicated lower urinary tract infections in women. Reviews of Infectious Diseases 1990;12(3): 458-67. [MedLine: 2193352].

\section{Schulz 1995}

Schulz KF, Chalmers I, Hayes RJ, Altman DG. Empirical evidence of bias. Dimensions of methodological quality associated with estimates of treatment effects in controlled trials. JAMA 1995;273(5):408-12. [MedLine: 7823387].

\section{Stamm 1980}

Stamm WE, Wagner KF, Amsel R, Alexander ER, Turck M, Counts GW, et al. Causes of the acute urethral syndrome in women. New England Journal of Medicine 1980;303(8):409-15. [MedLine: 6993946].

\section{Stamm 1982}

Stamm WE, Counts GW, Running KR, Fihn S, Turck M, Holmes KK. Diagnosis of coliform infection in acutely dysuric women. New England Journal of Medicine 1982;307(8):463-8. [MedLine: 7099208].

\section{Stamm 1991}

Stamm WE, McKevitt M, Roberts PL, White NJ. Natural history of recurrent urinary tract infections in women. Reviews of Infectious Diseases 1991;13(1):77-84. [MedLine: 2017637].

*Indicates the major publication for the study

T A B LE S

\section{Characteristics of included studies}

\begin{tabular}{ll} 
Study & Basista $\mathbf{1 9 9 1}$ \\
\hline Methods & Randomisation: computer-generated \\
& Blinding: none \\
& Intention-to-treat: no information \\
& Interim analysis: no information \\
& Excluded for efficacy analysis: $40 / 97$ patients $(19+21)-25$ of them $(14+11)$ due to negative urine cultures \\
& Excluded for safety analysis: $3 / 97(2+1)$ \\
& Follow-up: 4 to 10 days after treatment \\
\hline Participants & USA $(8$ centers) \\
& 97 patients (over $90 \%$ - female and white) \\
& Age: $18-84$ (mean $=33)$ \\
& Data collection: no information \\
\hline
\end{tabular}

Duration of antibacterial treatment for uncomplicated urinary tract infection in women (Review) 


\section{Characteristics of included studies (Continued)}

\begin{tabular}{|c|c|}
\hline & Bacteriuria $>10^{\wedge} 5 \mathrm{CFU} / \mathrm{ml}$ \\
\hline Interventions & $\begin{array}{l}\text { ofloxacin } 200 \mathrm{mg} \times 1 \text { for } 3 \text { days } \\
\text { vs } \\
\text { TMP-SMX } 160 / 800 \mathrm{mg} \times 2 \text { for } 7 \text { days }\end{array}$ \\
\hline Outcomes & $\begin{array}{l}\text { Clinical cure (but results not shown) } \\
\text { Bacteriological cure } \\
\text { Adverse effects }\end{array}$ \\
\hline Notes & $\begin{array}{l}90 \% \text { - female and white (the exact number of males not mentioned) } \\
\text { Age: } 18-84 \\
\text { The trial was terminated early by the sponsor's medical monitor after } 97 \text { patients (instead of 150) involved } \\
\text { Different antibiotics were compared }\end{array}$ \\
\hline Allocation concealment & A - Adequate \\
\hline Study & Bitsch 1985 \\
\hline Methods & $\begin{array}{l}\text { Randomisation: sealed envelopes method } \\
\text { Blinding: no information } \\
\text { Intention-to-treat: no information } \\
\text { Interim analysis: no information } \\
\text { Excluded: } 84 / 394 \text { ( } 30 \text { - no urine cultures was taken; } 41 \text { - no significant bacteriuria; } 13 \text { - dropouts) } \\
\text { Follow-up : } 2 \text { days and } 10 \text { weeks after end of treatment }\end{array}$ \\
\hline Participants & $\begin{array}{l}\text { Denmark } \\
394 \text { patients }(92 \%-\text { non-pregnant women }) \\
\text { Age: } 16-70(\text { mean }=38) \\
\text { Data collection: } 5 / 81-5 / 82 \\
\text { Bacteriuria }>10 \wedge 5 \mathrm{CFU} / \mathrm{ml}\end{array}$ \\
\hline Interventions & $\begin{array}{l}\text { pivmecillinam } 400 \mathrm{mg} \times 3 \text { for } 3 \text { days } \\
\text { vs } \\
\text { sulfametizol } 1 \mathrm{~g} \times 2 \text { for } 6 \text { days }\end{array}$ \\
\hline Outcomes & $\begin{array}{l}\text { Clinical cure } \\
\text { Bacteriological cure } \\
\text { Adverse effects }\end{array}$ \\
\hline Notes & $\begin{array}{l}-8 \% \text { ( } 25 \text { of } 310 \text { included in efficacy analysis) were males but results for women with uncomplicated lower } \\
\text { UTI only can be separated } \\
\text { Different antibiotics were compared }\end{array}$ \\
\hline Allocation concealment & A - Adequate \\
\hline
\end{tabular}

\begin{tabular}{ll} 
Study & Butler $\mathbf{1 9 8 3}$ \\
\hline Methods & Randomisation: randomised list \\
& Blinding: no information \\
& Intention-to-treat: no information \\
& Interim analysis: no information \\
& Excluded for clinical efficacy: 16/141 (12 - lost to follow-up; 3 - stopped treatment due to side effects; 1 - \\
& admitted to hospital due to gastritis) \\
& Excluded for bacteriological efficacy analysis: $75 / 141$ (no significant bacteriuria) \\
& Follow-up: 2-3 days after end of treatment and 4 week after it \\
\hline Participants & UK \\
& Age: 110 non-pregnant (modian=20) \\
\hline
\end{tabular}




\section{Characteristics of included studies (Continued)}

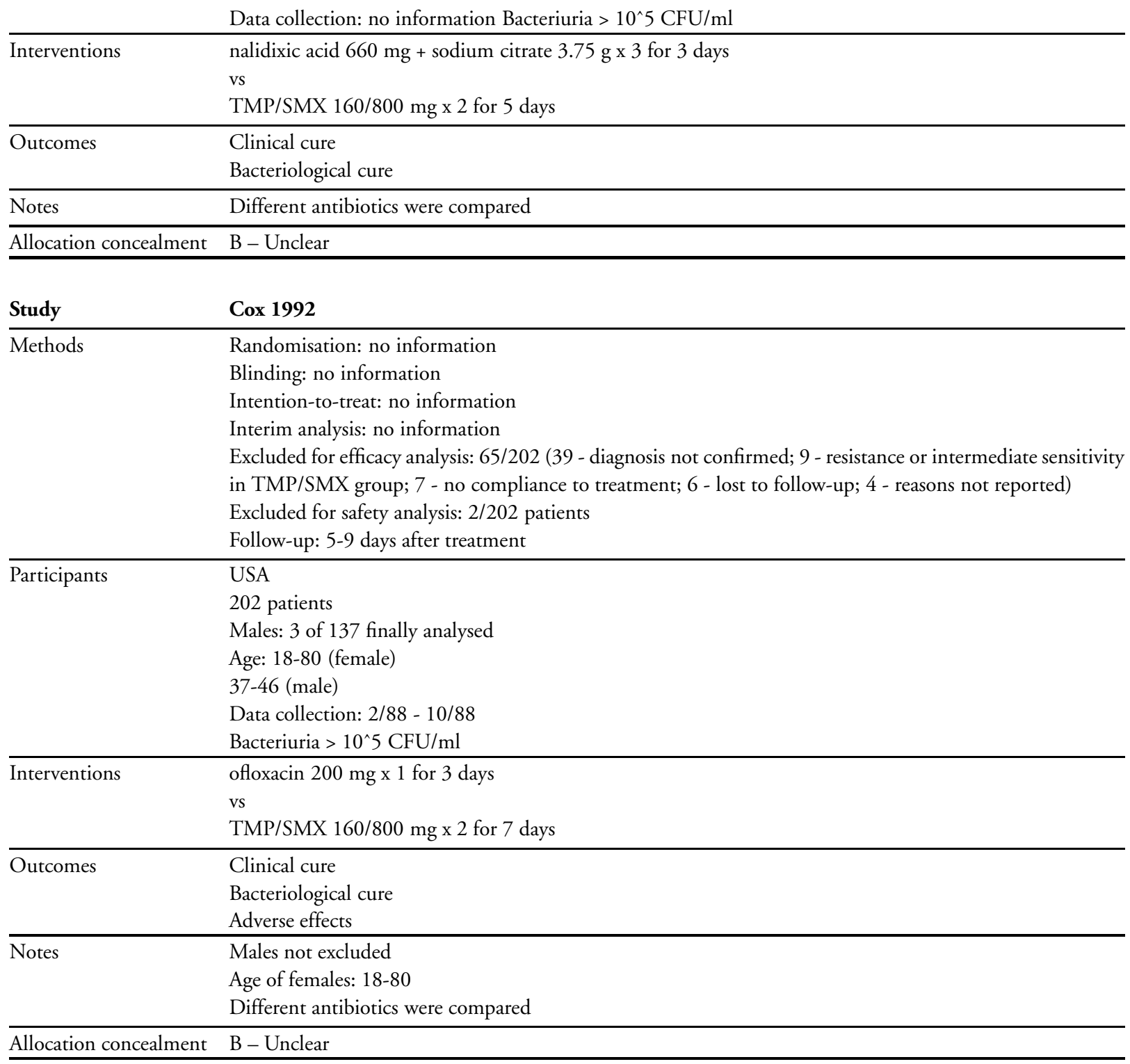

\section{Study}

\section{Figueroa 1999}

Methods

Randomisation: no information

Blinding: No

Intention-to-treat: no information

Interim analysis: no information

Follow-up: 7-10 days and 21-28 days after treatment

\begin{tabular}{ll}
\hline Participants & Mexico \\
& 60 non-pregnant women
\end{tabular}

Age: $18-50$

Bacteriuria $>10 \wedge 5 \mathrm{CFU} / \mathrm{ml}$

Data collection: no information

Interventions ceftibuten $400 \mathrm{mg}$ single dose vs 


\section{Characteristics of included studies (Continued)}

\begin{tabular}{|c|c|}
\hline & $\begin{array}{l}\text { ceftibuten } 400 \mathrm{mg} \times 1 \text { for } 3 \text { days } \\
\text { vs } \\
\text { TPM/SMX } 160 / 800 \mathrm{mg} \times 2 \text { for } 7 \text { days }\end{array}$ \\
\hline Outcomes & $\begin{array}{l}\text { Clinical cure } \\
\text { Bacteriological cure } \\
\text { Adverse effects }\end{array}$ \\
\hline Notes & $\begin{array}{l}\text { Different antibiotics were compared } \\
\text { Additional group of patients was studied - a single-dose of ceftibuten } \\
\text { Only short-term results shown }\end{array}$ \\
\hline Allocation concealment & B - Unclear \\
\hline Study & Garcia 2002 \\
\hline Methods & $\begin{array}{l}\text { Randomisation: no information } \\
\text { Blinding: no information } \\
\text { Intention-to-treat: no information } \\
\text { Interim analysis: no information } \\
\text { Excluded for efficacy analysis: } 33 / 151 \text { ( } 5 \text { - bacteria resistant to norfloxacin; } 12 \text { - negative cultures; } 16 \text { - lost } \\
\text { for follow-up) } \\
\text { Follow-up: } 3 \text { days and } 30 \text { days after treatment }\end{array}$ \\
\hline Participants & $\begin{array}{l}\text { Spain } \\
151 \text { non-pregnant women } \\
\text { Age: above } 18 \\
\text { Data collection: } 1998-1999 \\
\text { Bacteriuria > } 10^{\wedge} 5 \mathrm{CFU} / \mathrm{ml}\end{array}$ \\
\hline Interventions & $\begin{array}{l}\text { norfloxacin } 400 \mathrm{mg} \times 2 \text { for } 3 \text { days } \\
\text { vs } \\
\text { norfloxacin } 400 \mathrm{mg} \times 2 \text { for } 7 \text { days }\end{array}$ \\
\hline$\overline{\text { Outcomes }}$ & $\begin{array}{l}\text { Clinical cure } \\
\text { Bacteriological cure }\end{array}$ \\
\hline$\overline{\text { Notes }}$ & $\begin{array}{l}\text { Upper age limit not mentioned } \\
\text { Only short-term results shown }\end{array}$ \\
\hline Allocation concealment & B - Unclear \\
\hline Study & Gordin 1987a \\
\hline Methods & $\begin{array}{l}\text { Randomisation: latin square method } \\
\text { Blinding: No } \\
\text { Intention-to-treat: no information } \\
\text { Interim analysis: no information } \\
\text { Excluded to efficacy analysis: } 27 / 159 \text { (20- negative urine cultures; 4- lost to follow-up; 3- discontinued } \\
\text { treatment due to side effects) } \\
\text { Follow-up : 3-5 days and } 4 \text { weeks after treatment }\end{array}$ \\
\hline Participants & $\begin{array}{l}\text { Finland } \\
159 \text { women } \\
\text { Age }: 17-63(\text { mean }=32) \\
\text { Data collection }: 9 / 82-10 / 84 \\
\text { Bacteriuria }>10 \wedge 5 \mathrm{CFU} / \mathrm{ml}\end{array}$ \\
\hline Interventions & $\begin{array}{l}\text { TMP-sulfadiazine }(160 \mathrm{mg}+500 \mathrm{mg}) \times 2 \text { for } 3 \text { days } \\
\text { vs } \\
\text { TMP-sulfadiazine }(160 \mathrm{mg}+500 \mathrm{mg}) \times 2 \text { for } 10 \text { days }\end{array}$ \\
\hline
\end{tabular}

Duration of antibacterial treatment for uncomplicated urinary tract infection in women (Review) 


\section{Characteristics of included studies (Continued)}

\begin{tabular}{|c|c|}
\hline Outcomes & $\begin{array}{l}\text { Bacteriological cure } \\
\text { Adverse effects }\end{array}$ \\
\hline Notes & $\begin{array}{l}7 \text { of } 159 \text { - patients with asymptomatic bacteriuria included } \\
\text { A trial with } 4 \text { groups was analysed as two separate subtrials }\end{array}$ \\
\hline Allocation concealment & A - Adequate \\
\hline Study & Gordin $1987 b$ \\
\hline Methods & $\begin{array}{l}\text { Randomisation: latin square method } \\
\text { Blinding: No } \\
\text { Intention-to-treat: no information } \\
\text { Interim analysis: no information } \\
\text { Excluded to efficacy analysis: } 27 / 159 \text { (20- negative urine cultures; } 4 \text { - lost to follow-up; 3- discontinued } \\
\text { treatment due to side effects) } \\
\text { Follow-up: 3-5 days and } 4 \text { weeks after treatment }\end{array}$ \\
\hline Participants & $\begin{array}{l}\text { Finland } \\
159 \text { women } \\
\text { Age: } 17-63(\text { mean }=32) \\
\text { Data collection : } 9 / 82-10 / 84 \\
\text { Bacteriuria > } 10^{\wedge} 5 \mathrm{CFU} / \mathrm{ml}\end{array}$ \\
\hline Interventions & $\begin{array}{l}\text { pivmecillinam } 200 \mathrm{mg} \text { x } 3 \text { for } 3 \text { days } \\
\text { vs } \\
\text { pivmecillinam } 200 \mathrm{mg} \text { x } 3 \text { for } 10 \text { days }\end{array}$ \\
\hline Outcomes & $\begin{array}{l}\text { Bacteriological cure } \\
\text { Adverse effects }\end{array}$ \\
\hline Notes & $\begin{array}{l}7 \text { of } 159 \text { - patients with asymptomatic bacteriuria included } \\
\text { A trial with } 4 \text { groups was analysed as two separate subtrials }\end{array}$ \\
\hline Allocation concealment & A - Adequate \\
\hline
\end{tabular}

\begin{tabular}{|c|c|}
\hline Study & Gossius 1984 \\
\hline Methods & $\begin{array}{l}\text { Randomisation: no information } \\
\text { Blinding: no information } \\
\text { Intention-to-treat: no information } \\
\text { Interim analysis: no information } \\
\text { Excluded - 185/464 (143 - negative cultures; } 7 \text { - resistant organisms; } 11 \text { - lost to follow up; } 24 \text { - adverse } \\
\text { reactions necessitated cessation of treatment) } \\
\text { (Side effects assessed in } 408 \text { patients) } \\
\text { Follow-up period: } 2 \text { weeks and } 6 \text { weeks after treatment }\end{array}$ \\
\hline Participants & $\begin{array}{l}\text { Norway } \\
464 \text { women } \\
\text { Age: } 16-60 \\
\text { Data collection: no information } \\
\text { Bacteriuria }>10^{\wedge} 5 \mathrm{CFU} / \mathrm{ml}\end{array}$ \\
\hline Interventions & $\begin{array}{l}\text { TMP-SMX (160mg+800mg) x } 2 \text { for } 3 \text { days } \\
\text { vs } \\
\text { TMP-SMX( } 160 \mathrm{mg}+800 \mathrm{mg}) \times 2 \text { for } 10 \text { days }\end{array}$ \\
\hline Outcomes & $\begin{array}{l}\text { Clinical cure } \\
\text { Bacteriological cure } \\
\text { Adverse effects }\end{array}$ \\
\hline
\end{tabular}




\section{Characteristics of included studies (Continued)}

Notes Additional group of patients was studied - a single-dose TMP-SMX

Allocation concealment $\mathrm{B}-$ Unclear

Study

Methods

\section{Gossius 1985}

Randomisation: boxes with code numbers and tablets wrapped in plain alluminium foil

Blinding: no information

Intention-to-treat: no information

Interim analysis: no information

Excluded: 63/135 (44 - nonsignificant pre-therapy bacteriuria; 6 - lost to follow up; 2 - initially resistant organisms; 1 - developed pyelonephritis(in 3-day group); 7 - side effects leading to therapy cessation)

Follow-up: 2 and 6 weeks after treatment

\begin{tabular}{ll}
\hline Participants & Norway \\
& 135 women \\
& Age: 16 to 60 \\
& Data collection: no information \\
& Bacteriuria $>10 \wedge 5 \mathrm{CFU} / \mathrm{ml}$ \\
\hline Interventions & TMP $200 \mathrm{mg} \times 2$ for 3 days \\
& vs \\
& TMP $200 \mathrm{mg} \times 2$ for 10 days \\
\hline Outcomes & Clinical cure \\
& Bacteriological cure \\
& Adverse effects (for 114 patients who completed treatment) \\
\hline Notes & Clinical response for patients without significant bacteriuria mentioned for total number (not devided for \\
& the treatment groups) \\
\hline Allocation concealment & B - Unclear \\
\hline
\end{tabular}

Study

Greenberg 1986

Methods

Randomisation: no information

Blinding: no information

Intention-to-treat: no information

Interim analysis: no information

Excluded: 15/126 at 3-days follow-up visit ; 49/126 at 2-weeks follow-up visit

Follow-up: 3 days, 2 weeks and 4 weeks post-therapy

\begin{tabular}{ll}
\hline Participants & USA \\
& 126 non-pregnant women \\
& Age: $>12$ \\
& Data collection: $4 / 83-11 / 84$ \\
& Bacteriuria $>10^{\wedge} 5 \mathrm{CFU} / \mathrm{ml}$ \\
\hline Interventions & cefadroxil $1 \mathrm{~g}$ single dose \\
& vs \\
& cefadroxil $500 \mathrm{mg} \times 2$ for 3 days \\
& vs \\
& cefadroxil $500 \mathrm{mg} \times 2$ for 7 days \\
& vs \\
& TMP/SMX $320 / 1600 \mathrm{mg}$ single dose \\
& vs \\
& TMP/SMX $160 / 800 \mathrm{mg} \times 2$ for 3 days \\
\hline Outcomes & Clinical cure \\
& Bacteriological cure
\end{tabular}

Duration of antibacterial treatment for uncomplicated urinary tract infection in women (Review)

Copyright $\odot 2007$ The Cochrane Collaboration. Published by John Wiley \& Sons, Ltd 


\section{Characteristics of included studies (Continued)}

\begin{tabular}{|c|c|}
\hline & Adverse effects \\
\hline Notes & $\begin{array}{l}\text { Different antibiotics were compared } \\
\text { Two additional groups of single dose treatment } \\
\text { Only two groups (cefadroxil } 500 \mathrm{mg} \times 2 \text { for } 3 \text { vs } 7 \text { days) will be analysed here }\end{array}$ \\
\hline Allocation concealment & B - Unclear \\
\hline Study & Guibert 1997 \\
\hline Methods & $\begin{array}{l}\text { Randomisation: no information } \\
\text { Blinding: no information } \\
\text { Intention-to-treat: yes } \\
\text { Interim analysis: no information } \\
\text { Follow-up: } 14 \text { days after end of treatment } \\
\text { Excluded to clinical efficacy analysis: } 81 / 421 \text { (non-compliance to study protocol) }\end{array}$ \\
\hline Participants & $\begin{array}{l}\text { France } \\
421 \text { non-pregnant women } \\
\text { Data collection : } \\
12 / 94-6 / 95 \\
\text { Bacteriuria: not defined (case definition by clinical signs and symptoms) }\end{array}$ \\
\hline Interventions & $\begin{array}{l}\text { lomefloxacin } 400 \mathrm{mg} \text { x } 1 \text { for } 3 \text { days } \\
\text { vs } \\
\text { norfloxacin } 400 \mathrm{mg} \text { x } 2 \text { for } 10 \text { days }\end{array}$ \\
\hline Outcomes & $\begin{array}{l}\text { Clinical cure } \\
\text { Adverse effects }\end{array}$ \\
\hline Notes & $\begin{array}{l}\text { Different antibiotics were compared } \\
\text { Bacteriuria: not defined }\end{array}$ \\
\hline Allocation concealment & B - Unclear \\
\hline
\end{tabular}

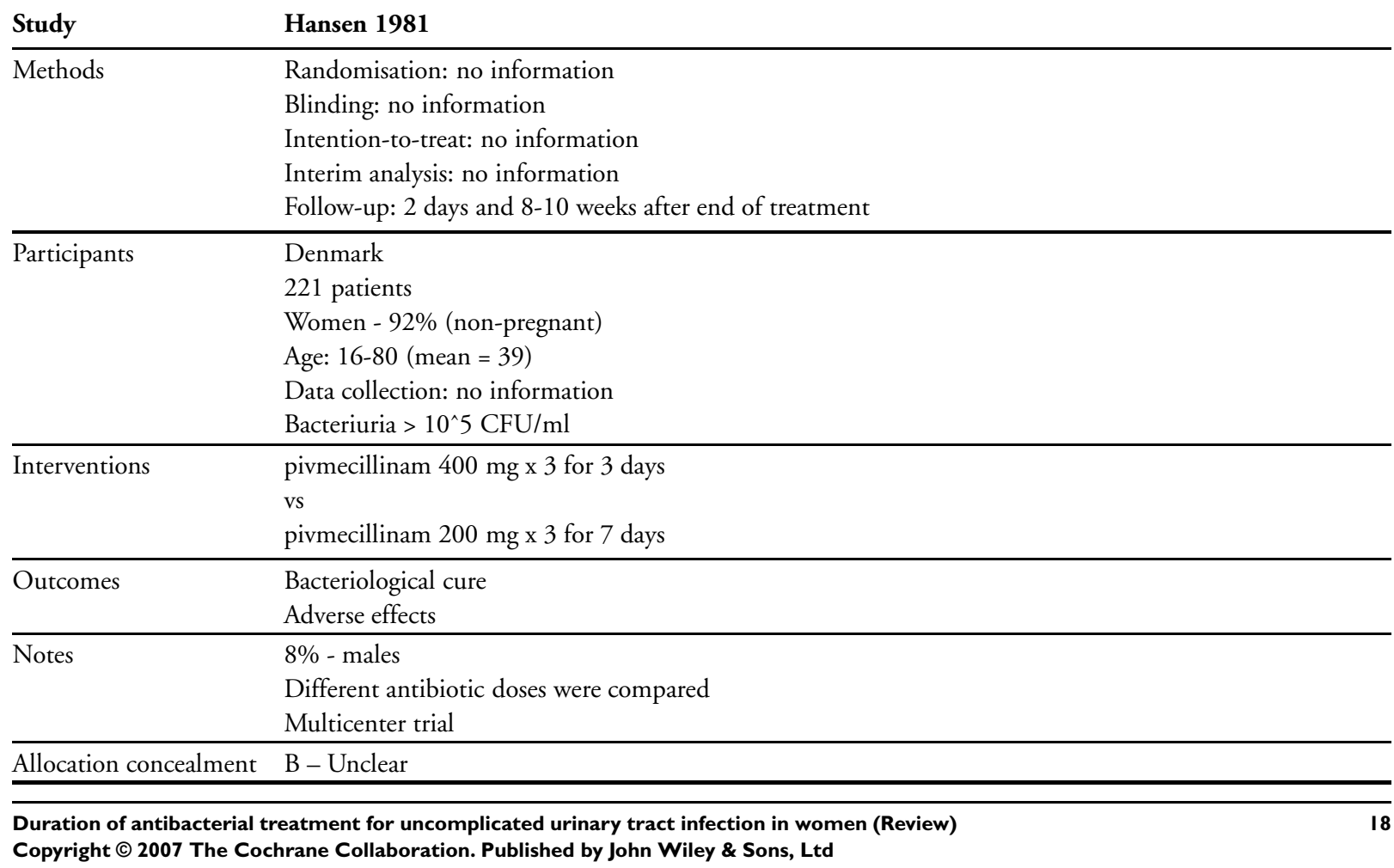




\section{Characteristics of included studies (Continued)}

\section{Study}

Methods

\section{Henry 1999}

Randomisation: allocation numbers generated by the pharmaceutic company; cards with the listing of the medication distributed to the centers

Blinding: double-blinded, double-dummy

Intention-to-treat: Yes

Interim analysis : no information

Excluded to clinical efficacy analysis: 221/1175

Excluded to bacteriological efficacy analysis: 685/1175

Follow-up: 13 to 15 days after beginning of the treatment and 4 to 6 weeks after therapy

\begin{tabular}{ll}
\hline Participants & USA \\
& 1175 non-pregnant women \\
& Age: $18-64$ (mean=34) \\
& Data collection: $1 / 94-2 / 95$ \\
& Bacteriuria $>10^{\wedge} 5 \mathrm{CFU} / \mathrm{ml}$ \\
\hline Interventions & sparfloxacin $400 \mathrm{mg}$ single dose \\
& vs \\
& sparfloxacin $400 \mathrm{mg}$ on the first day followed by $200 \mathrm{mg} \times 1$ (3 days total) \\
& vs \\
& ciprofloxacin $250 \mathrm{mg}$ x 2 for 7 days \\
\hline Outcomes & Clinical cure \\
& Bacteriological cure \\
& Adverse effects \\
\hline Notes & Multicenter trial \\
Additional group of single-dose drug \\
Higher percentage of patients with previous urinary tract surgery in the 7-day group \\
More drop-out in the 7 -day group than in 2 other groups \\
Different antibiotics were compared \\
\hline A-Adequate
\end{tabular}

Study

Hooton 1991

Methods

Randomisation: computer-generated randomization list provided by pharmaceutical company, patients allocated sequentially

Blinding: none

Intention-to-treat: no information

Interim analysis: no information

Excluded to efficacy analysis: 6/150 (5 - no significant bacteriuria; 1 - no follow-up)

Follow-up: 5-9 days and 4-6 weeks after treatment

\begin{tabular}{ll}
\hline Participants & USA \\
& 150 non-pregnant women
\end{tabular}

Age: $>18($ mean $=24-25)$

Data collection : no information

Bacteriuria $>10 \wedge 2 \mathrm{CFU} / \mathrm{ml}$ with symptoms or Bacteriuria $>10^{\wedge} 5 \mathrm{CFU} / \mathrm{ml}$ asymptomatic

Interventions ofloxacin $400 \mathrm{mg}$ single dose

vs

ofloxacin $200 \mathrm{mg}$ x 1 for 3 days

vs

TMP/SMX 160/800 mg x 2 for 7 days

Outcomes

Bacteriological cure

Adverse effects

Duration of antibacterial treatment for uncomplicated urinary tract infection in women (Review)

Copyright ( 2007 The Cochrane Collaboration. Published by John Wiley \& Sons, Ltd 


\section{Characteristics of included studies (Continued)}

Notes

Significant bacteriuria defined as $>10^{\wedge} 2 \mathrm{CFU} / \mathrm{ml}+$ symptoms or pyuria Asymptomatic bacteriuria treated

Different antibiotics were compared

Additional single dose group

Allocation concealment $\mathrm{A}-$ Adequate

Study

Hovelius 1985

Methods

Randomisation: sealed envelopes with treatment protocol

Blinding: No

Intention-to-treat: no information

Interim analysis: no information

Excluded: 38/160 - No significant bacteriuria

Follow-up: 1 week and 4 weeks after treatment

\begin{tabular}{ll}
\hline Participants & Sweden \\
& 160 women \\
& Age: $15-45$ \\
& Data collection: no information \\
& Bacteriuria $>10 \wedge 4 \mathrm{CFU} / \mathrm{ml}$ \\
\hline Interventions & pivmecillinam $400 \mathrm{mg} \times 3$ for 3 days \\
& vs \\
& pivmecillinam $200 \mathrm{mg} \times 3$ for 7 days \\
& (and \\
& nalidixic acid $1 \mathrm{~g} \times 3$ for 3 vs 7 days) \\
\hline Outcomes & Bacteriological cure \\
& Adverse effects \\
\hline Notes & 1) Only pivmecillinam groups can be analysed due to treatment regimen change in patients of nalidixic acid \\
& groups \\
& 2) Different doses of pivmecillinam were used \\
& 3) 2 patients with S.saprophyticus <10^4 CFU included separately \\
& 4) Age: $15-45$ \\
\hline Allocation concealment & B - Unclear
\end{tabular}

\begin{tabular}{ll} 
Study & Internordic 1988 \\
\hline Methods & Randomisation: no information \\
& Blinding: double-blinded \\
& Intention-to-treat: no information \\
& Interim analysis: no information \\
& Excluded for safety analysis: $6 / 485$ patients \\
& Excluded for efficacy analysis: $112 / 485$ (84 - no significant bacteriuria; 3 - lost to follow-up; 8 - treatment \\
& less than 13 doses; 17 - others) \\
& Follow-up: "short-term" - 3 to 13 days after treatment and "accumulated efficacy" - worst result 3 until 45 \\
& days after treatment \\
\hline Participants & Norway, Sweden \\
& 485 non-pregnant women \\
& Age: $18-80$ \\
& Data collection: $11 / 85-6 / 87$ \\
& Bacteriuria $>10 \wedge 5$ CFU/ml for Gram-negative and $10 \wedge 4$ for Staphylococcus saprophyticus \\
\hline Interventions & norfloxacin $400 \mathrm{mg} \times 2$ for 3 days \\
& vs \\
& norfloxacin $400 \mathrm{mg}$ x 2 for 7 days \\
\hline
\end{tabular}

Duration of antibacterial treatment for uncomplicated urinary tract infection in women (Review)

Copyright @ 2007 The Cochrane Collaboration. Published by John Wiley \& Sons, Ltd 


\section{Characteristics of included studies (Continued)}

\begin{tabular}{|c|c|}
\hline Outcomes & $\begin{array}{l}\text { Clinical cure } \\
\text { Bacteriological cure } \\
\text { Adverse effects }\end{array}$ \\
\hline Notes & $\begin{array}{l}\text { Age: } 18-80 \\
\text { Multicenter trial }\end{array}$ \\
\hline Allocation concealment & B - Unclear \\
\hline Study & Iravani 1983 \\
\hline Methods & $\begin{array}{l}\text { Randomisation: no information } \\
\text { Blinding: no information } \\
\text { Intention-to-treat: no information } \\
\text { Interim analysis: no information } \\
\text { Excluded: } 12 / 158 \text { (reasons not mentioned) } \\
\text { Follow-up: } 1,2 \text { and } 4 \text { weeks after treatment }\end{array}$ \\
\hline Participants & $\begin{array}{l}\text { USA } \\
158 \text { women college students } \\
\text { Data collection: no information } \\
\text { Bacteriuria }>10^{\wedge} 5 \mathrm{CFU} / \mathrm{ml}\end{array}$ \\
\hline Interventions & $\begin{array}{l}\text { sulfisoxazole } 2 \mathrm{~g} \text { as first dose followed by } \\
\text { sulfisoxazole } 1 \mathrm{~g} \text { x } 4 \text { for } 3 \text { days } \\
\text { vs } \\
\text { sulfisoxazole } 1 \mathrm{~g} \text { x } 4 \text { for } 7 \text { days } \\
\text { vs } \\
\text { sulfisoxazole } 1 \mathrm{~g} \text { x } 4 \text { for } 14 \text { days } \\
\text { vs } \\
\text { sulfisoxazole } 1 \mathrm{~g} \text { x } 4 \text { for } 21 \text { days }\end{array}$ \\
\hline Outcomes & $\begin{array}{l}\text { Clinical cure } \\
\text { Bacteriological cure }\end{array}$ \\
\hline Notes & $\begin{array}{l}30 \text { patients had costovertebral tenderness on examination } \\
\text { Age not mentioned ("college coeds") } \\
\text { Groups of } 7,14 \text { and } 21 \text { days will be analysed together (“multi-days") }\end{array}$ \\
\hline Allocation concealment & B - Unclear \\
\hline Study & Iravani 1999 \\
\hline Methods & $\begin{array}{l}\text { Randomisation: opaque gelatin capsules with medication or placebo } \\
\text { Blinding: double blinded } \\
\text { Intention-to-treat: yes } \\
\text { Interim analysis: no information } \\
\text { Excluded: } 192 / 713 \text { (128 - negative cultures; } 28 \text { - cultures not obtained; } 14 \text { - entry criteria violations; } 12 \text { - } \\
\text { inadequate duration of treatment; } 3 \text { - insufficient pretreatment colony counts; } 3 \text { - administration of con- } \\
\text { cominant antibiotics; } 2 \text { - noncompliance; } 1 \text { - no follow-up; } 1 \text { - resistant organism) } \\
\text { Follow-up: 4-10 days and 4-6 weeks after treatment }\end{array}$ \\
\hline Participants & $\begin{array}{l}\text { USA } \\
713 \text { women } \\
\text { Age: } 18-85 \\
\text { Data collection : no information } \\
\text { Bacteriuria }>10 \wedge 3 \mathrm{CFU} / \mathrm{ml}\end{array}$ \\
\hline Interventions & $\begin{array}{l}\text { ciprofloxacin } 100 \mathrm{mg} \text { x } 2 \text { for } 3 \text { days } \\
\text { vs }\end{array}$ \\
\hline
\end{tabular}

Duration of antibacterial treatment for uncomplicated urinary tract infection in women (Review) 


\section{Characteristics of included studies (Continued)}

\begin{tabular}{|c|c|}
\hline & $\begin{array}{l}\text { TMP-SMX 160/800 mg x } 2 \text { or } \\
\text { nitrofurantoin } 100 \mathrm{mg} \times 2 \text { for } 7 \text { days }\end{array}$ \\
\hline Outcomes & $\begin{array}{l}\text { Clinical cure } \\
\text { Bacteriological cure } \\
\text { Adverse effects }\end{array}$ \\
\hline Notes & $\begin{array}{l}\text { Different antibiotics were compared } \\
\text { Multicenter trial } \\
\text { Age: } 18-85 \\
\text { Bacteriuria }>10^{\wedge} 3 \mathrm{CFU} / \mathrm{ml} \\
\text { Two groups of } 7 \text {-days treatment will be analysed together }\end{array}$ \\
\hline Allocation concealment & A - Adequate \\
\hline Study & Marsh 1980 \\
\hline Methods & $\begin{array}{l}\text { Randomisation: randomised list } \\
\text { Blinding: no information } \\
\text { Intention-to-treat: no information } \\
\text { Interim analysis: no information } \\
\text { Excluded for clinical efficacy: } 16 / 141 \text { (12 - lost to follow-up; } 3 \text { - stopped treatment due to side effects; } 1 \text { - } \\
\text { admitted to hospital due to gastritis) } \\
\text { Excluded for bacteriological efficacy analysis: } 75 / 141 \text { (no significant bacteriuria) } \\
\text { Follow-up: } 2-3 \text { days after end of treatment and } 4 \text { week after it }\end{array}$ \\
\hline Participants & $\begin{array}{l}\text { UK } \\
141 \text { non-pregnant women } \\
\text { Age: } 15-55 \\
\text { Data collection: no information } \\
\text { Bacteriuria }>10^{\wedge} 5 \mathrm{CFU} / \mathrm{ml} \\
\end{array}$ \\
\hline Interventions & $\begin{array}{l}\text { pivmecillinam (dose not mentioned) for } 3 \text { days } \\
\text { vs } \\
\text { pivmecillinam (dose not mentioned) for } 7 \text { days }\end{array}$ \\
\hline Outcomes & $\begin{array}{l}\text { Clinical cure } \\
\text { Bacteriological cure } \\
\text { Adverse effects }\end{array}$ \\
\hline Notes & $\begin{array}{l}\text { Results of clinical cure are presented in the form of symptom score (mean and range) - cannot be analysed } \\
\text { here } \\
\text { Doses of antibiotics not mentioned }\end{array}$ \\
\hline Allocation concealment & B - Unclear \\
\hline
\end{tabular}

\begin{tabular}{ll} 
Study & Menday 2000 \\
\hline Methods & Randomisation: no information \\
& Blinding: double-blind (double-dummy technique) \\
& Excluded for efficacy analysis: $224 / 440\left(129-<10^{\wedge} 5 \mathrm{CFU} / \mathrm{ml}\right.$ of bacterial pathogen; 37 - inadequate urinary \\
& cultures; $54-$ bacteria in vitro susceptibility not confirmed; 3 - non-compliance or concominant antibiotic \\
& use; 2 - violated protocol inclusion criteria) \\
& Follow-up: day $10(+/-2)$ and day $14(+/-2)$ from the beginning of treatment \\
\hline Participants & UK \\
& 440 patients \\
& Women: 212 of 216 patients included in efficacy analysis \\
& Age: $18-87$ years \\
& Bacteriuria $>10 \wedge 5 \mathrm{CFU} / \mathrm{ml}$ \\
\hline
\end{tabular}

Duration of antibacterial treatment for uncomplicated urinary tract infection in women (Review) 


\section{Characteristics of included studies (Continued)}

\begin{tabular}{|c|c|}
\hline Interventions & $\begin{array}{l}\text { pivmecillinam } 200 \mathrm{mg} \text { x } 3 \text { for } 3 \text { days } \\
\text { vs } \\
\text { cephalexin } 250 \mathrm{mg} \text { x } 4 \text { for } 7 \text { days }\end{array}$ \\
\hline Outcomes & $\begin{array}{l}\text { Clinical cure } \\
\text { Bacteriological cure } \\
\text { Adverse effects }\end{array}$ \\
\hline Notes & $\begin{array}{l}\text { Different antibiotics doses were compared } \\
\text { Age: } 18-87 \text { years } \\
4 \text { of } 216 \text { patients included in efficacy analysis were men } \\
\text { Results of clinical cure and improvement are presented together (it's impossible to separate between them) }\end{array}$ \\
\hline Allocation concealment & B - Unclear \\
\hline Study & Neringer 1992 \\
\hline Methods & $\begin{array}{l}\text { Randomisation: computer-generated randomisation schedule } \\
\text { Blinding: double-dummy method } \\
\text { Intention-to-treat: no information } \\
\text { Interim analysis: no information } \\
\text { Excluded for efficacy analysis: 116/703 (no significant bacteriuria) } \\
\text { Follow-up : 5-9 days posttreatment and "accumulated results" at 3-4 weeks posttreatment }\end{array}$ \\
\hline Participants & $\begin{array}{l}\text { Sweden } \\
703 \text { non-pregnant women } \\
\text { Age : } 18-65 \\
\text { Data collection }: 8 / 88-1 / 90 \\
\text { Bacteriuria }>10^{\wedge} 4 \mathrm{CFU} / \mathrm{ml} \\
\end{array}$ \\
\hline Interventions & $\begin{array}{l}\text { lomefloxacin } 400 \mathrm{mg} \times 1 \text { for } 3 \text { days } \\
\text { vs } \\
\text { lomefloxacin } 400 \mathrm{mg} \times 1 \text { for } 7 \text { days } \\
\text { vs } \\
\text { norfloxacin } 400 \mathrm{mg} \times 2 \text { for } 7 \text { days }\end{array}$ \\
\hline Outcomes & $\begin{array}{l}\text { Clinical cure } \\
\text { Bacteriological cure } \\
\text { Adverse effects }\end{array}$ \\
\hline$\overline{\text { Notes }}$ & $\begin{array}{l}\text { One additional group of another antibiotic was included as a 7-day treatment (norfloxacin) } \\
\text { Only two groups (lomefloxacin } 400 \mathrm{mg} \text { x } 1 \text { for } 3 \text { vs } 7 \text { days) will be analysed here }\end{array}$ \\
\hline Allocation concealment & A-Adequate \\
\hline
\end{tabular}

\begin{tabular}{ll} 
Study & Piipo 1990 \\
\hline Methods & Randomisation: no information \\
& Blinding: double-blind \\
& Intention-to-treat: no information \\
& Interim analysis: no information \\
& Excluded for efficacy analysis: $73 / 400$ (60 - no significant bacteriuria; 4 - no posttreatment cultures; 4 - \\
& change to other antibiotics; 4 - patients did not take drugs as prescribed; 1 - lost for follow-up) \\
& Follow-up: 3 to 13 days posttreatment and accumulated efficacy (worst result 3 days posttreatment to day \\
& 45 after treatment start) \\
\hline Participants & Finland \\
& 400 non-pregnant women \\
& Age: $18-80$ \\
& Data collection : no information
\end{tabular}




\section{Characteristics of included studies (Continued)}

\begin{tabular}{|c|c|}
\hline Interventions & $\begin{array}{l}\text { norfloxacin } 400 \mathrm{mg} \text { x } 2 \text { for } 3 \text { days } \\
\text { vs } \\
\text { norfloxacin } 400 \mathrm{mg} \times 2 \text { for } 7 \text { days }\end{array}$ \\
\hline Outcomes & $\begin{array}{l}\text { Clinical cure } \\
\text { Bacteriological cure } \\
\text { Adverse effects }\end{array}$ \\
\hline Notes & Age: $18-80$ (results for accumulated long-term efficacy showed for women 18 to 65 years old separately) \\
\hline Allocation concealment & A - Adequate \\
\hline Study & Pitkajarvi 1990 \\
\hline Methods & $\begin{array}{l}\text { Randomisation: envelope method } \\
\text { Blinding: no information } \\
\text { Intention-to-treat: yes } \\
\text { Interim analysis: none } \\
\text { Excluded for clinical and bacteriologicl effect: } 46 / 345 \text { (no growth in th urine cultures) - } 23 \text { in both groups } \\
\text { Follow-up: } 5 \text { days and } 4-5 \text { weeks after treatment }\end{array}$ \\
\hline Participants & $\begin{array}{l}\text { Finland } \\
345 \text { women } \\
\text { Age: } 16-65 \text { (mean }=35) \\
\text { Data collection: no information } \\
\text { Bacteriuria }>10^{\wedge} 5 \mathrm{CFU} / \mathrm{ml}\left(10^{\wedge} 4 \text { for Staphylococcus saprophyticus) }\right.\end{array}$ \\
\hline Interventions & $\begin{array}{l}\text { pivmecillinam } 400 \mathrm{mg} \text { x } 3 \text { for } 3 \text { days } \\
\text { vs } \\
\text { pivmecillinam } 200 \mathrm{mg} \text { × } 3 \text { for } 7 \text { days }\end{array}$ \\
\hline Outcomes & $\begin{array}{l}\text { Clinical cure } \\
\text { Bacteriological cure } \\
\text { Adverse effects }\end{array}$ \\
\hline Notes & Different antibiotics doses were compared \\
\hline Allocation concealment & B - Unclear \\
\hline
\end{tabular}

\section{Study}

Methods

\section{Rapoport 1981}

Randomisation: no information

Blinding: no information

Intention-to-treat: no information

Interim analysis: none

Excluded: all the cases without significant bacteriuria; 16 of 91 with bacteriuria (lost at follow-up)

Follow-up: 10 to 14 days after treatment

\begin{tabular}{ll}
\hline Participants & UK \\
& 187 patients \\
& Women: 69 of 75 included in an \\
& Mean age: $45(14-78)$ \\
& Data collection: $3 / 79-10 / 79$ \\
& Bacteriuria $>10^{\wedge} 5$ CFU $/ \mathrm{ml}$ \\
\hline Interventions & TMP-SMX 2 tabs x 1 for 3 days \\
& vs \\
& different drugs* for 7 days
\end{tabular}

Duration of antibacterial treatment for uncomplicated urinary tract infection in women (Review) 
Characteristics of included studies (Continued)

(* TMP-SMX - 17, sulfamethizole - 4, sulfadimidine - 4, amoxicillin - 6, mecillinam - 2, nalidixic acid - 2, nitrofurantoin -2 )

\begin{tabular}{|c|c|}
\hline Outcomes & $\begin{array}{l}\text { Clinical cure } \\
\text { Bacteriological cure }\end{array}$ \\
\hline Notes & $\begin{array}{l}\text { Age: } 14-78 \text { years } \\
\text { Different antibiotics were compared } \\
\text { No outcomes in subgroups of antibiotics in the 7-days group } \\
6 \text { of } 75 \text { included in the analysis are males }\end{array}$ \\
\hline Allocation concealment & B - Unclear \\
\hline Study & Richards 1984 \\
\hline Methods & $\begin{array}{l}\text { Randomisation: numbered sealed envelopes (opaque not mentioned) } \\
\text { Blinding: Single blinded (investigator) } \\
\text { Intention-to-treat: no information } \\
\text { Interim analysis: no information } \\
\text { Excluded - } 8 \text { of } 183 \text { ( } 3 \text { - not completed the course due to side effects; } 3 \text { - lost to follow-up; } 1 \text { - age > 55; } 1 \text { - } \\
\text { change in treatment due to worsening symptoms) } \\
\text { Follow-up: } 1 \text { week after treatment }\end{array}$ \\
\hline 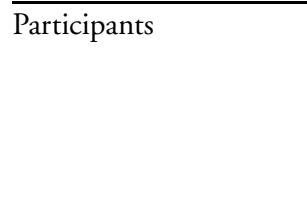 & $\begin{array}{l}\text { UK } \\
183 \text { non-pregnant women } \\
\text { Age: } 17-55 \\
\text { Data collection: no information } \\
\text { Bacteriuria }>10^{\wedge} 5 \mathrm{CFU} / \mathrm{ml}\end{array}$ \\
\hline Interventions & $\begin{array}{l}\text { pivmecillinam } 400 \mathrm{mg} \times 2 \text { for } 3 \text { days } \\
\text { vs } \\
\text { pivmecillinam } 400 \mathrm{mg} \times 2 \text { for } 7 \text { days }\end{array}$ \\
\hline Outcomes & $\begin{array}{l}\text { Clinical cure } \\
\text { Bacteriological cure } \\
\text { Adverse effects }\end{array}$ \\
\hline$\overline{\text { Notes }}$ & Multicentre study \\
\hline Allocation concealment & A-Adequate \\
\hline
\end{tabular}

\begin{tabular}{ll} 
Study & Sandberg 1985 \\
\hline Methods & Randomisation: randomisation tables, sealed opaque envelopes containing the allocation number \\
& Blinding: none (open) \\
& Intention-to-treat: no information \\
& Interim analysis: yes (Henning 1982) \\
& Excluded : $80 / 310(39-$ non-significant bacteriuria; 11 - unknown urine test results; 10 - resistant bacteria; \\
& 13 - sensitivity testing for antibiotic not performed; 4 - lost to follow-up; 1 - male; 2 - known anomalies of \\
& urinary tract) \\
& Follow-up: 1 week and 5 weeks after the end of treatment \\
\hline Participants & Sweden \\
& 310 non-pregnant women \\
& Age: $16-76$ (mean $=35.7)$ \\
& Data collection : $9 / 81-12 / 82$ \\
& Bacteriuria $>10^{\wedge} 5$ CFU/ml (10^4 for Staphylococcus saprophyticus) \\
\hline cefadroxil $1 \mathrm{~g} \times 1$ for 3 days \\
vs \\
cefadroxil $1 \mathrm{~g} \times 1$ for 7 days
\end{tabular}

Duration of antibacterial treatment for uncomplicated urinary tract infection in women (Review) 


\section{Characteristics of included studies (Continued)}

\begin{tabular}{ll} 
& vs \\
& amoxycillin $375 \mathrm{mg}$ x 3 for 7 days \\
\hline Outcomes & Both clinical and bacteriological cure \\
& Adverse effects \\
\hline Notes & Different antibiotics were compared \\
& Two groups of 7-days treatment with different antibiotics were compared with one 3-days group \\
& Only two groups (cefadroxil $1 \mathrm{~g}$ x 1 for 3 vs 7 days) will be analysed here \\
& Interim analysis= Henning1982 \\
\hline Allocation concealment & A-Adequate \\
\hline
\end{tabular}

\section{Study}

Stein 1987

Methods

Randomisation: a preassigned random - number code

Blinding: none

Intention-to-treat: yes

Interim analysis: no information

Excluded for efficacy analysis: No significant bacteriuria; Not available for follow-up

Follow-up: 5 to 9 days , 4 to 6 weeks

\begin{tabular}{ll}
\hline Participants & USA \\
& 209 patients \\
& $(192$ of 209 - women $)$ \\
& Age: $17-85$ \\
& Data collection: no information \\
& Bacteriuria $>10 \wedge 5 \mathrm{CFU} / \mathrm{ml}$ \\
\hline Interventions & norfloxacin $400 \mathrm{mg} \times 2$ for 3 days \\
& vs \\
& TMP-SMX $160 / 800 \mathrm{mg} \times 2$ for 10 days \\
\hline Outcomes & Clinical cure \\
& Bacteriological cure \\
& Adverse effects \\
\hline Notes & Age: $17-85$ \\
& Different antibiotics were compared \\
& 17 of 209 patients - males \\
\hline Allocation concealment & B - Unclear \\
\hline
\end{tabular}

\begin{tabular}{ll} 
Study & Stein $\mathbf{1 9 9 2}$ \\
\hline Methods & Randomisation: a preassigned random - number code \\
& Blinding: double-blind \\
& Intention-to-treat: no information \\
& Interim analysis: no information \\
& Excluded for efficacy evaluation: 184/404 (most common reason - lack of pretherapy urinary pathogen) \\
& No drop-outs to safety analysis \\
& Follow-up: 5 to 9 days after completion of therapy \\
\hline Participants & USA \\
& 404 non-pregnant women \\
& Age : $>18$ mean $=44 ; 81 / 404$ - age 65 or more \\
& Data collection: no information \\
& Bacteriuria $>10 \wedge 4$ CFU/ml \\
\hline Interventions & temafloxacin $400 \mathrm{mg} \times 1$ for 3 days \\
& vs \\
\hline
\end{tabular}

Duration of antibacterial treatment for uncomplicated urinary tract infection in women (Review) 


\section{Characteristics of included studies (Continued)}

\begin{tabular}{|c|c|}
\hline Outcomes & $\begin{array}{l}\text { Clinical cure } \\
\text { Bacteriological cure } \\
\text { Adverse effects } \\
\end{array}$ \\
\hline Notes & $\begin{array}{l}81 / 404 \text { - age } 65 \text { or more } \\
\text { Different antibiotics were compared }\end{array}$ \\
\hline Allocation concealment & B - Unclear \\
\hline Study & Trienekens 1989 \\
\hline Methods & $\begin{array}{l}\text { Randomisation: no information } \\
\text { Blinding: double dummy technique, placebo tablets identical to active drug } \\
\text { Intention-to-treat: no information } \\
\text { Interim analysis: no information } \\
\text { Follow-up: } 1,2 \text { and } 6 \text { weeks after entry }\end{array}$ \\
\hline Participants & $\begin{array}{l}\text { The Netherlands } \\
327 \text { non-pregnant women } \\
\text { Age: } 12-65 \\
\text { Data collection : } 1 / 88-4 / 89 \\
\text { Bacteriuria }>10^{\wedge} 5 \mathrm{CFU} / \mathrm{ml}\end{array}$ \\
\hline Interventions & $\begin{array}{l}\text { TMP-SMX } 960 \mathrm{mg} \text { x } 2 \text { for } 3 \text { days } \\
\text { vs } \\
\text { TMP-SMX } 960 \mathrm{mg} \text { x } 2 \text { for } 7 \text { days }\end{array}$ \\
\hline Outcomes & $\begin{array}{l}\text { Clinical cure } \\
\text { Bacteriological cure } \\
\text { Adverse effects } \\
\end{array}$ \\
\hline Notes & Age: $12-65$ \\
\hline Allocation concealment & B - Unclear \\
\hline
\end{tabular}

\begin{tabular}{|c|c|}
\hline Study & Trienekens 1993 \\
\hline Methods & $\begin{array}{l}\text { Randomisation: the code was supplied by pharmaceutic company and was not known to the investigators, } \\
\text { it was kept in the sealed envelopes that was broken } 6 \text { weeks after the last patient was included } \\
\text { Blinding: double dummy technique, placebo tablets identical to active drug } \\
\text { Intention-to-treat: no information } \\
\text { Interim analysis: no information } \\
\text { Excluded: } 11 / 395 \text { (not returned for follow-up) } \\
\text { Follow-up: } 1 \text { week and } 6 \text { weeks (only for bacteriological cure) }\end{array}$ \\
\hline Participants & $\begin{array}{l}\text { The Netherlands } \\
395 \text { non-pregnant women } \\
\text { Age: } 18-65 \\
\text { Data collection: } 4 / 89-10 / 90 \\
\text { Bacteriuria > } 10 \wedge 5 \mathrm{CFU} / \mathrm{ml}\end{array}$ \\
\hline Interventions & $\begin{array}{l}\text { norfloxacin } 400 \mathrm{mg} \text { x } 2 \text { for } 3 \text { days } \\
\text { vs } \\
\text { norfloxacin } 400 \mathrm{mg} \times 2 \text { for } 7 \text { days }\end{array}$ \\
\hline Outcomes & $\begin{array}{l}\text { Clinical cure } \\
\text { Bacteriological cure } \\
\text { Adverse effects }\end{array}$ \\
\hline Notes & \\
\hline
\end{tabular}




\section{Characteristics of included studies (Continued)}

Allocation concealment A-Adequate

Study

Methods

Tsugawa 1999

Randomisation: no information

Blinding: double-blind

Intention-to-treat: no information

Interim analysis: no information

Excluded for efficacy analysis: 28/99 (14 - no significant bacteriuria; 1 - withdrawal of informed consent; 2 - urinary tract infection within 4 weeks before treatment; 2 - lost for follow-up; 1 - fungi in urine before therapy; 3 - shortage of dosage; 1 - prohibited medication; 1 - anamnesis of epilepsy; 1 - 71 years or older; 1 - out of target disease)

Follow-up: days 7, 14 and 35 from the treatment start

\begin{tabular}{ll}
\hline Participants & Japan \\
& 99 women \\
& Age: $20-70$ \\
& Bacteriuria $>10 \wedge 4 \mathrm{CFU} / \mathrm{ml}$ \\
\hline Interventions & gatifloxacin $100 \mathrm{mg} \times 2$ for 3 days \\
& vs \\
& gatifloxacin $100 \mathrm{mg} \times 2$ for 7 days \\
\hline Outcomes & Clinical cure \\
& Bacteriological cure \\
& Adverse effects \\
\hline Notes & Age: $20-70$ \\
\hline Allocation concealment & B - Unclear \\
\hline
\end{tabular}

Study

Winwick 1981

Methods

Randomisation: no information

Blinding: no information

Intention-to-treat: no information

Interim analysis: no information

Excluded: 23/81 ("not fulfilled the stipulated criteria for entry")

Follow-up: 14 days after treatment start

Participants UK

81 non-pregnant women

Age : $18-65($ mean $=34)$

Data collection: no information

Bacteriuria: no information

\begin{tabular}{ll}
\hline Interventions & nalidixic acid + sodium citrate $\times 3$ for 3 days \\
& vs \\
& ampicillin $500 \mathrm{mg} \times 3$ for 7 days
\end{tabular}

Outcomes Bacteriological cure

Adverse effects

Notes

Exact dosage of antibiotic in the 3-day group not mentioned (probably - $660 \mathrm{mg}+3.75 \mathrm{~g}$ )

Different antibiotics were compared

Allocation concealment $\mathrm{B}-$ Unclear

TMP = trimethoprim

SMX = sulfamethoxazole

$\mathrm{CFU}=$ colony-forming units

Duration of antibacterial treatment for uncomplicated urinary tract infection in women (Review)

Copyright @ 2007 The Cochrane Collaboration. Published by John Wiley \& Sons, Ltd 


\section{Characteristics of excluded studies}

\begin{tabular}{|c|c|}
\hline Study & Reason for exclusion \\
\hline Bailey 1983 & $\begin{array}{l}\text { New Zealand } \\
\text { Randomised controlled study } \\
\text { Compares } 2 \text { treatment regimens } 5 \text { days duration both }\end{array}$ \\
\hline Bargelloni 1972 & $\begin{array}{l}\text { Italy } \\
\text { Not randomised controlled study } \\
\text { Phase III trial }\end{array}$ \\
\hline Blomer 1986 & $\begin{array}{l}\text { West Germany } \\
\text { Not randomised controlled study } \\
\text { Review - not systematic }\end{array}$ \\
\hline Charlton 1976 & $\begin{array}{l}\text { UK } \\
\text { Quasi-randomisation (alternate months) }\end{array}$ \\
\hline Fair 1980 & $\begin{array}{l}\text { USA } \\
\text { Quasi-randomisation (alternate patients) }\end{array}$ \\
\hline Fancourt 1984 & $\begin{array}{l}\text { UK } \\
\text { Randomised controlled study } \\
\text { Inpatients only } \\
\text { Compares } 2 \text { treatment regimens both of } 7 \text { days duration (does not include a 3-day regimen) }\end{array}$ \\
\hline Furusawa 1994 & $\begin{array}{l}\text { Japan } \\
\text { Not randomised controlled study } \\
\text { Case reports }\end{array}$ \\
\hline Gellerman 1988 & $\begin{array}{l}\text { Germany } \\
\text { Randomised controlled study } \\
\text { Compares single dose and three-days regimens of ciprofloxacin }\end{array}$ \\
\hline Hill 1985 & $\begin{array}{l}\text { UK } \\
\text { Randomised controlled study } \\
\text { Compares } 2 \text { treatment regimens } 10 \text { days duration both (does not include a 3-day regimen) }\end{array}$ \\
\hline Hoigne 1977 & $\begin{array}{l}\text { Switzerland } \\
\text { Clinical controlled study } \\
\text { Compares treatment for } 2 \text { weeks and for } 4 \text { weeks }\end{array}$ \\
\hline Hooton 1989 & $\begin{array}{l}\text { USA } \\
\text { Review of two randomised controlled studies : } \\
\text { 1) comparing } 2 \text { treatment regimens of } 3 \text { days both } \\
\text { 2) comparing } 2 \text { treatment regimens of } 7 \text { days both }\end{array}$ \\
\hline Iravani 1991 & $\begin{array}{l}\text { USA } \\
\text { Review of } 3 \text { different studies (only one of them - randomised controlled study and included separately) }\end{array}$ \\
\hline Iravani 1995 & $\begin{array}{l}\text { USA } \\
\text { Review of } 3 \text { separate studies }\end{array}$ \\
\hline Ishihara 1998 & $\begin{array}{l}\text { Japan } \\
\text { RCT } \\
\text { Results - only clinical improvement and not cure }\end{array}$ \\
\hline Little 1979 & $\begin{array}{l}\text { New Zealand } \\
\text { Randomised controlled study } \\
\text { Compares several treatment regimens all of wich were } 5 \text { to } 7 \text { days long (does not include a 3-day regimen) }\end{array}$ \\
\hline Liudvig 1996 & Germany \\
\hline
\end{tabular}

Duration of antibacterial treatment for uncomplicated urinary tract infection in women (Review)

Copyright @ 2007 The Cochrane Collaboration. Published by John Wiley \& Sons, Ltd 


\section{Characteristics of excluded studies (Continued)}

Not randomised controlled study

\begin{tabular}{|c|c|}
\hline Loran 1997 & $\begin{array}{l}\text { Russia } \\
\text { Not randomised controlled study (case-control study) }\end{array}$ \\
\hline Martin 1983 & $\begin{array}{l}\text { UK } \\
\text { Randomised controlled study } \\
\text { Compares } 2 \text { treatment regimens both of } 7 \text { days duration (does not include a 3-day regimen) }\end{array}$ \\
\hline McCarthy 1972 & $\begin{array}{l}\text { USA } \\
\text { Randomised controlled study } \\
\text { Compares } 2 \text { treatment regimens } 10 \text { days duration both }\end{array}$ \\
\hline Pelta 1985 & $\begin{array}{l}\text { UK } \\
\text { Randomised controlled study } \\
\text { Compares } 2 \text { treatment regimens } 7 \text { days duration both (does not include a 3-day regimen) }\end{array}$ \\
\hline Raz 1996 & $\begin{array}{l}\text { Israel } \\
\text { Randomised controlled study } \\
\text { Only postmenopausal women (mean age }=66+1-20 \text { years) }\end{array}$ \\
\hline Schultz 1984 & $\begin{array}{l}\text { USA } \\
\text { Randomised controlled study } \\
\text { Compares single-dose with 10-days antibiotic regimens (does not include a 3-day regimen) }\end{array}$ \\
\hline Vogel 1984 & $\begin{array}{l}\text { UK } \\
\text { A summary of few studies comparing different regimens of 3-days therapy and 7-days therapy separately (neither } \\
\text { comparing 3-days treatment to 7-days) }\end{array}$ \\
\hline Zorbas 1995 & $\begin{array}{l}\text { Greece } \\
\text { Randomised controlled study } \\
\text { Duration of all treatment regimens }-12 \text { weeks (does not include a 3-day regimen) } \\
\text { Only elderly patients (mean age }=82.8 \text { years) }\end{array}$ \\
\hline
\end{tabular}

\section{A D D I T I O N L TABLE S}

Table 01. Electronic search strategies

Database searched

CENTRAL

\section{Terms used}

\#1) URINARY TRACT INFECTIONS

\#2) (urinary next tract next infection*)

\#3) uti and utis

\#4) bacteriuria*

\#5) pyuria*

\#6) (\#1 or \#2 or \#3 or \#4 or \#5)

\#7) ANTI-INFECTIVE AGENTS

\#8) anti-infective*

\#9) antiinfective*

\#10) antibiotic*

\#11) quinoline*

\#12) cinoxacin

\#13) (nalidixic next acid)

\#14) (oxolinic next acid)

\#15) fluoroquinolone*

\#16) ciprofloxacin 


\section{Table 01. Electronic search strategies (Continued)}

Database searched

MEDLINE

\section{Terms used}

\#17) enoxacin

\#18) fleroxacin

\#19) norfloxacin

\#20) ofloxacin

\#21) perfloxacin

$\# 22)$ (\#8 or \#9 or \#10 or \#11 or \#12 or \#13 or \#14 or \#15 or \#16 or \#17 or \#18 or \#19 or \#20 or \#21)

\#23) (\#6 and \#22)

1. exp Urinary Tract Infections/

2. urinary tract infection $\$$.tw.

3. uti.tw.

4. utis.tw.

5. pyuria.tw.

6. bacteriuria.tw.

7. or/1-6

8. exp Anti-Infective Agents/

9. anti-infective $\$ . t w$.

10. antiinfective\$.tw.

11. antibiotic\$.tw.

12. antibacterial\$.tw.

13. quinolone\$.tw.

14. cinoxacin.tw.

15. nalidixic acid.tw.

16. oxolinic acid.tw.

17. fluoroquinolone.tw.

18. ciprofloxacin.tw.

19. enoxacin.tw.

20. fleroxacin.tw.

21. norfloxacin.tw.

22. ofloxacin.tw.

23. pefloxacin.tw.

24. or/8-23

25.7 and 24

26. randomized controlled trial.pt.

27. controlled clinical trial.pt.

28. randomized controlled trials/

29. random allocation/

30. double blind method/

31. single blind method/

32. or/26-31

33. animal/ not (animal/ and human/)

34.32 not 33

35. clinical trial.pt.

36. exp clinical trials/

37. (clinic $\$$ adj25 trial\$).ti,ab.

38. cross-over studies/

39. (crossover or cross-over or cross over).tw.

40. ((singl\$ or doubl\$ or trebl\$ or tripl\$) adj25 (blind\$ or mask\$)).ti,ab.

41. placebos/

Duration of antibacterial treatment for uncomplicated urinary tract infection in women (Review) 
Table 01. Electronic search strategies (Continued)

Database searched

\author{
Terms used \\ 42. placebo\$.ti,ab. \\ 43. random\$.ti,ab. \\ 44. research design/ \\ 45. or/35- 44 \\ 46.45 not 33 \\ 47.34 or 46 \\ 48. 25 and 47
}

\title{
A N A L YS ES
}

\section{Comparison 01. Three days versus 5-10 day antibiotic therapy}

\begin{tabular}{|c|c|c|c|c|}
\hline Outcome title & $\begin{array}{l}\text { No. of } \\
\text { studies }\end{array}$ & $\begin{array}{c}\text { No. of } \\
\text { participants }\end{array}$ & Statistical method & Effect size \\
\hline $\begin{array}{l}01 \text { Short-term symptomatic } \\
\text { failure ( } 2-15 \text { days from end of } \\
\text { treatment) }\end{array}$ & 24 & 5165 & Relative Risk (Random) 95\% CI & $1.06[0.88,1.28]$ \\
\hline $\begin{array}{l}02 \text { Short-term symptomatic failure } \\
\text { - ITT (2-15 days from end of } \\
\text { treatment) }\end{array}$ & 17 & 5029 & Relative Risk (Random) 95\% CI & $0.98[0.88,1.10]$ \\
\hline $\begin{array}{l}03 \text { Long-term symptomatic failure } \\
\text { (4-10 weeks from end of } \\
\text { treatment) }\end{array}$ & 10 & 3141 & Relative Risk (Random) 95\% CI & $1.09[0.94,1.27]$ \\
\hline $\begin{array}{l}04 \text { Long-term symptomatic failure } \\
\text { - ITT (4-10 weeks from end of } \\
\text { treatment) }\end{array}$ & 10 & 3910 & Relative Risk (Random) 95\% CI & $1.07[0.99,1.16]$ \\
\hline $\begin{array}{l}05 \text { Short-term bacteriologic } \\
\text { failure ( } 2-15 \text { days from end of } \\
\text { treatment) }\end{array}$ & 31 & 5368 & Relative Risk (Random) 95\% CI & $1.19[0.98,1.44]$ \\
\hline $\begin{array}{l}06 \text { Short-term bacteriological } \\
\text { failure by antiboitic class (same } \\
\text { drug) (2-15 days from end of } \\
\text { treatment) }\end{array}$ & 18 & 3146 & Relative Risk (Random) 95\% CI & $1.37[1.07,1.74]$ \\
\hline $\begin{array}{l}07 \text { Short-term bacteriological } \\
\text { failure - ITT ( } 2-15 \text { days from } \\
\text { end of treatment) }\end{array}$ & 20 & 4163 & Relative Risk (Random) 95\% CI & $0.92[0.80,1.06]$ \\
\hline $\begin{array}{l}08 \text { Long-term bacteriological } \\
\text { failure ( } 4-10 \text { weeks from end of } \\
\text { treatment) }\end{array}$ & 18 & 3715 & Relative Risk (Random) 95\% CI & $1.31[1.08,1.60]$ \\
\hline $\begin{array}{l}09 \text { Long-term bacteriological } \\
\text { failure by antibiotic class (same } \\
\text { drug) ( } 4-10 \text { weeks from end of } \\
\text { treatment) }\end{array}$ & 13 & 2502 & Relative Risk (Random) 95\% CI & $1.43[1.19,1.73]$ \\
\hline $\begin{array}{l}10 \text { Long-term bacteriological } \\
\text { failure - ITT ( } 4-10 \text { weeks from } \\
\text { end of treatment) }\end{array}$ & 13 & 2943 & Relative Risk (Random) 95\% CI & $1.19[1.06,1.35]$ \\
\hline
\end{tabular}




\begin{tabular}{|c|c|c|c|c|}
\hline $\begin{array}{l}11 \text { Long-term bacteriological } \\
\text { failure - ITT by antibiotic class } \\
\text { (same drug) (4-10 weeks from } \\
\text { end of treatment) }\end{array}$ & 10 & 2127 & Relative Risk (Random) 95\% CI & $1.26[1.08,1.47]$ \\
\hline $\begin{array}{l}12 \text { Patients with any adverse effects } \\
\text { during treatment }\end{array}$ & 29 & 7617 & Relative Risk (Random) 95\% CI & $0.83[0.74,0.93]$ \\
\hline $\begin{array}{l}13 \text { Patients developed } \\
\text { pyelonephritis }\end{array}$ & 5 & 582 & Relative Risk (Random) 95\% CI & $3.04[0.32,28.93]$ \\
\hline $\begin{array}{l}14 \text { Adverse effects requiring } \\
\text { therapy discontinuation }\end{array}$ & 24 & 6177 & Relative Risk (Random) 95\% CI & $0.51[0.28,0.91]$ \\
\hline 15 Gastrointestinal adverse effects & 24 & 6973 & Relative Risk (Random) 95\% CI & $0.81[0.67,0.97]$ \\
\hline 16 Skin adverse effects & 21 & 6582 & Relative Risk (Random) 95\% CI & $0.62[0.36,1.06]$ \\
\hline 17 CNS adverse effects & 21 & 5748 & Relative Risk (Random) 95\% CI & $0.83[0.65,1.06]$ \\
\hline $\begin{array}{l}18 \text { Vaginal discharge as an adverse } \\
\text { effect of therapy }\end{array}$ & 18 & 5127 & Relative Risk (Random) 95\% CI & $0.73[0.49,1.10]$ \\
\hline 19 Other adverse effects & 19 & 5250 & Relative Risk (Random) 95\% CI & $0.98[0.72,1.32]$ \\
\hline $\begin{array}{l}20 \text { Patients with any adverse effects } \\
\text { during treatment by antibiotic } \\
\text { class (same drug) }\end{array}$ & 17 & 3852 & Relative Risk (Random) 95\% CI & $0.76[0.63,0.92]$ \\
\hline
\end{tabular}

\section{N D EX TERMS}

\section{Medical Subject Headings (MeSH)}

Anti-Infective Agents, Urinary [*therapeutic use]; Randomized Controlled Trials; Urinary Tract Infections [*drug therapy]

\section{MeSH check words}

Female; Humans

\section{COVER SHEET}

Title

\section{Authors}

\section{Contribution of author(s)}

Issue protocol first published

Review first published

Date of most recent amendment

Date of most recent SUBSTANTIVE amendment

What's New

Date new studies sought but none found
Duration of antibacterial treatment for uncomplicated urinary tract infection in women Milo G, Katchman EA, Paul M, Christiaens T, Baerheim A, Leibovici L

Gai Milo: Literature search, obtaining articles, Study selection, quality appraisal, data extraction, data analysis, writing review, updating review.

Mical Paul: Study selection, quality appraisal, data extraction, writing review

Thierry Christiaens: Data analysis, writing protocol and review.

Eugene Katchman: Data analysis, writing protocol and review.

Andres Barheim: Data analysis, writing protocol and review.

Leonard Leibovici: Data analysis, writing protocol and review.

$2001 / 3$

$2005 / 2$

13 December 2005

22 February 2005

Information not supplied by author

Information not supplied by author

Duration of antibacterial treatment for uncomplicated urinary tract infection in women (Review)

Copyright @ 2007 The Cochrane Collaboration. Published by John Wiley \& Sons, Ltd 
Date new studies found but not yet included/excluded

Date new studies found and included/excluded

Date authors' conclusions section amended

Contact address

\section{DOI}

Cochrane Library number

Editorial group

Editorial group code
Information not supplied by author

Information not supplied by author

Information not supplied by author

Dr Gai Milo

Department fo Internal Medicine E

Rabin Medical Center

Beilinson Campus

Petah-Tiqva

ISRAEL

E-mail: viv@inter.net.il

10.1002/14651858.CD004682.pub2

CD004682

Cochrane Renal Group

HM-RENAL 


\section{GRAPHS ANDOTHER TABLES}

Figure 0I. Funnel plot - symptomatic failure

Review: Duration of antibacterial treatment for uncomplicated urinary tract infection in women Comparison: 01 Three days versus $5-10$ day antibiotic therapy

Outcome: 01 Short-term symptomatic failure (2-15 days from end of treatment)

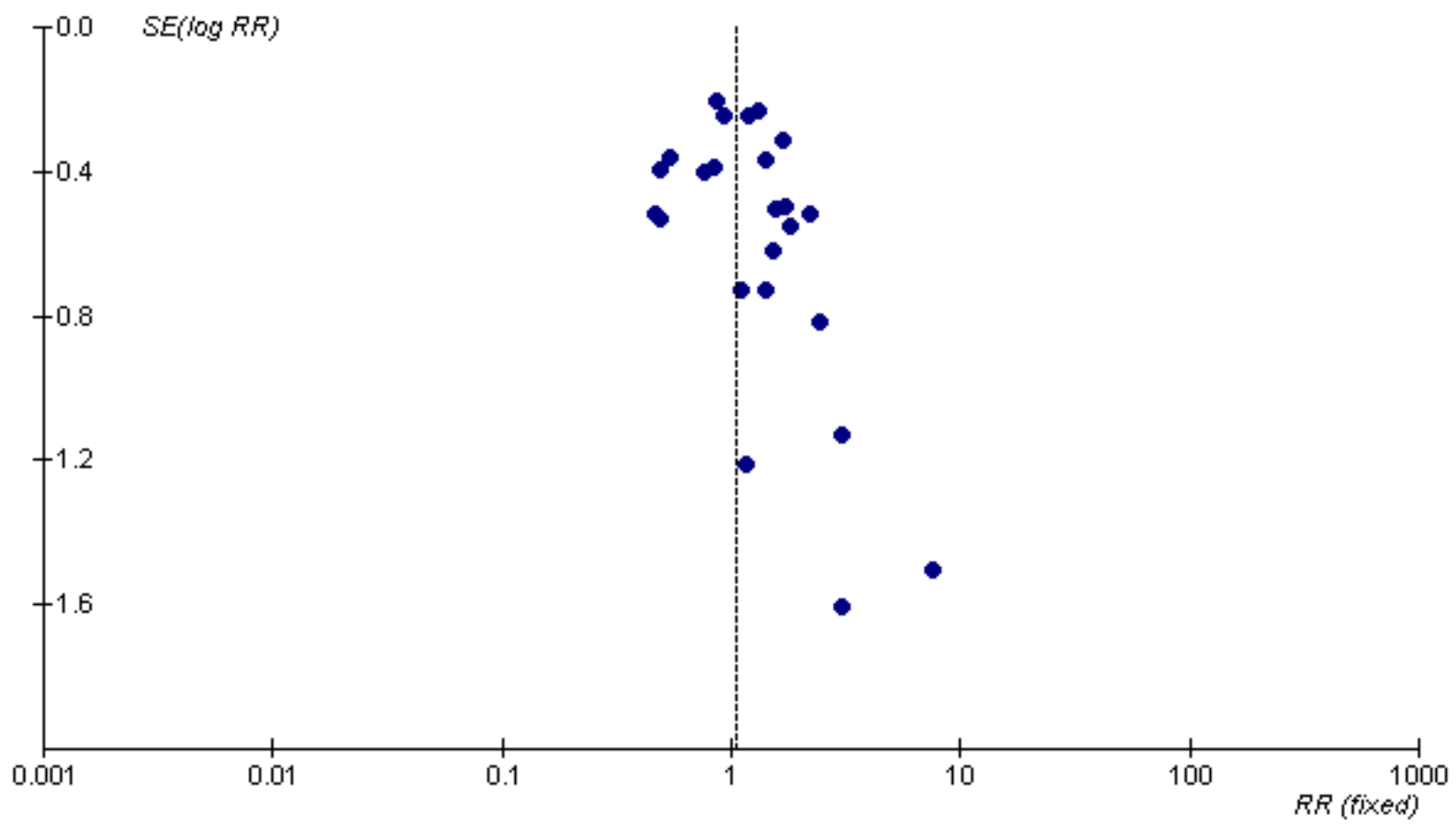


Figure 02. Funnel plot - bacteriologic failure

Review: Duration of antibacterial treatment for uncomplicated urinary tract infection in women Comparison: 01 Three days versus 5-10 day antibiotic therapy

Outcome: 05 Short-term bacteriologic failure (2-15 days from end of treatment)

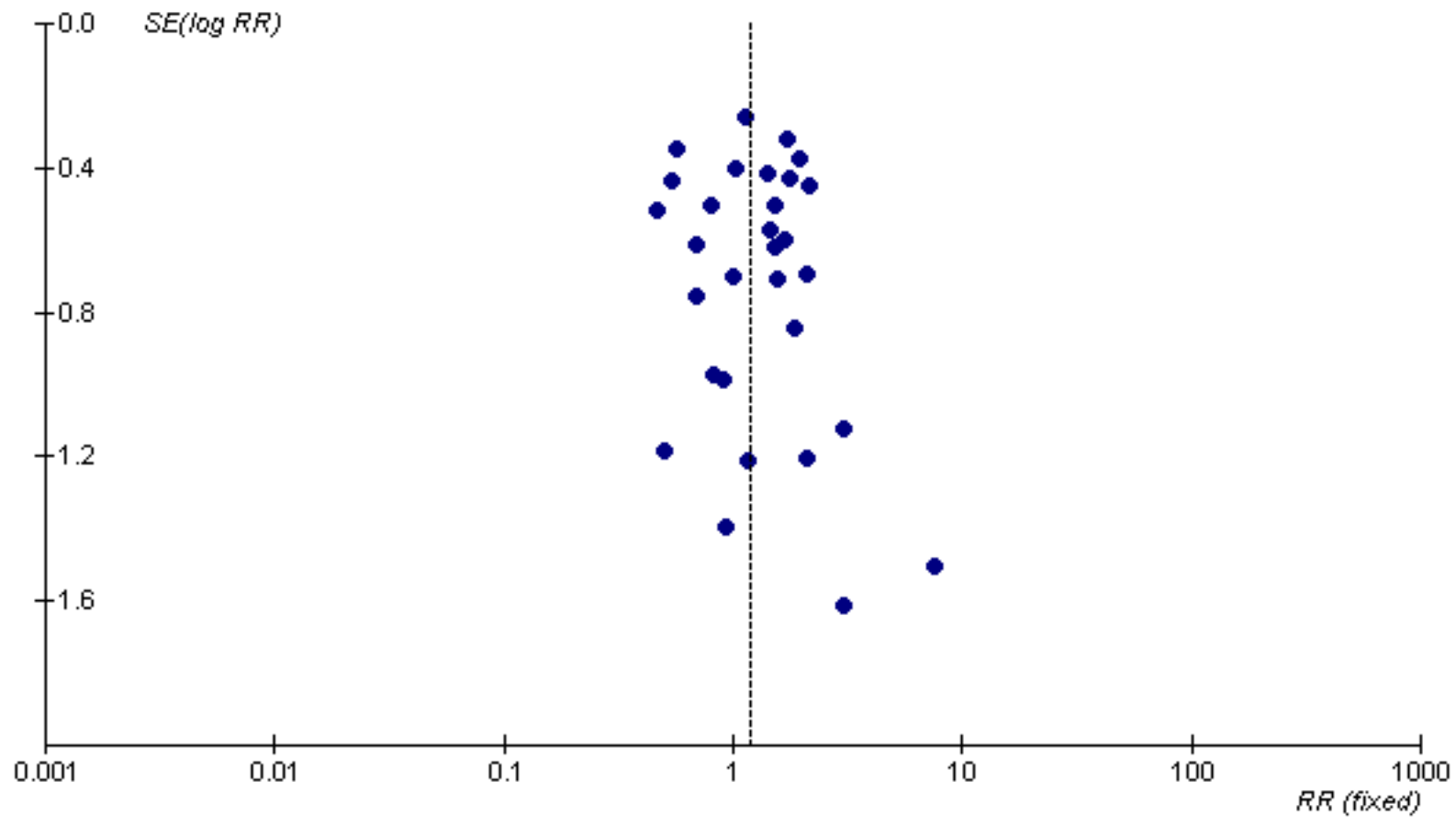




\section{Analysis 0I.0I. Comparison $0 \mathrm{I}$ Three days versus 5-10 day antibiotic therapy, Outcome $0 \mathrm{I}$ Short-term}

symptomatic failure (2-15 days from end of treatment)

Review: Duration of antibacterial treatment for uncomplicated urinary tract infection in women

Comparison: 01 Three days versus 5-10 day antibiotic therapy

Outcome: 01 Short-term symptomatic failure (2-15 days from end of treatment)

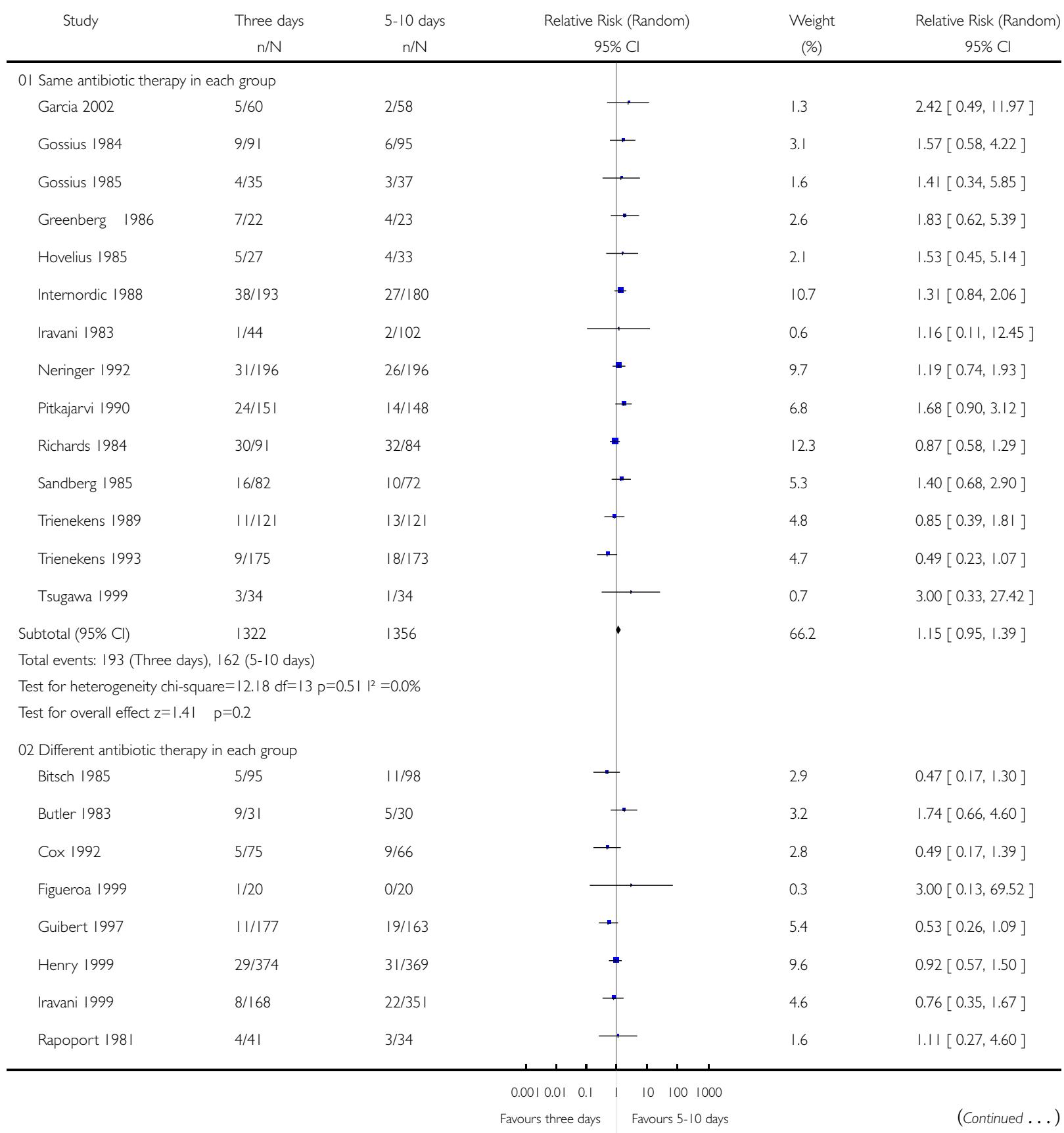

Duration of antibacterial treatment for uncomplicated urinary tract infection in women (Review) 


\begin{tabular}{|c|c|c|c|c|c|}
\hline Study & $\begin{array}{c}\text { Three days } \\
n / N\end{array}$ & $\begin{array}{c}5-10 \text { days } \\
n / N\end{array}$ & $\begin{array}{c}\text { Relative Risk (Random) } \\
95 \% \mathrm{Cl}\end{array}$ & $\begin{array}{c}\text { Weight } \\
(\%)\end{array}$ & $\begin{array}{c}\text { Relative Risk (Random) } \\
95 \% \mathrm{Cl}\end{array}$ \\
\hline Stein 1987 & $3 / 74$ & $0 / 81$ & 7 & 0.4 & $7.65[0.40,145.73]$ \\
\hline Stein 1992 & $12 / 115$ & $5 / 105$ & $\rightarrow$ & 3.0 & $2.19[0.80,6.01]$ \\
\hline Subtotal $(95 \% \mathrm{Cl})$ & 1170 & 1317 & $\bullet$ & 33.8 & $0.90[0.62,1.29]$ \\
\hline \multicolumn{6}{|c|}{ Total events: 87 (Three days), 105 (5-10 days) } \\
\hline \multicolumn{6}{|c|}{ Test for heterogeneity chi-square $=12.57 \mathrm{df}=9 \mathrm{p}=0.18 \mathrm{I}^{2}=28.4 \%$} \\
\hline \multicolumn{6}{|c|}{ Test for overall effect $z=0.59 \quad p=0.6$} \\
\hline Total $(95 \% \mathrm{Cl})$ & 2492 & 2673 & ' & 100.0 & $1.06[0.88,1.28]$ \\
\hline \multicolumn{6}{|c|}{ Total events: 280 (Three days), 267 (5-10 days) } \\
\hline \multicolumn{6}{|c|}{ Test for heterogeneity chi-square $=27.14 \mathrm{df}=23 \mathrm{p}=0.25 \mathrm{I}^{2}=15.3 \%$} \\
\hline Test for overall effe & $=0.5$ & & & & \\
\hline
\end{tabular}

\section{Analysis 01.02. Comparison 01 Three days versus 5-10 day antibiotic therapy, Outcome 02 Short-term} symptomatic failure - ITT (2-15 days from end of treatment)

Review: Duration of antibacterial treatment for uncomplicated urinary tract infection in women

Comparison: 01 Three days versus 5-10 day antibiotic therapy

Outcome: 02 Short-term symptomatic failure - ITT (2-15 days from end of treatment)
Study
Three days
5-10 days
Relative Risk (Random)
Relative Risk (Random)
95\% Cl

$\mathrm{n} / \mathrm{N}$

$\mathrm{n} / \mathrm{N}$

$95 \% \mathrm{Cl}$

(\%)

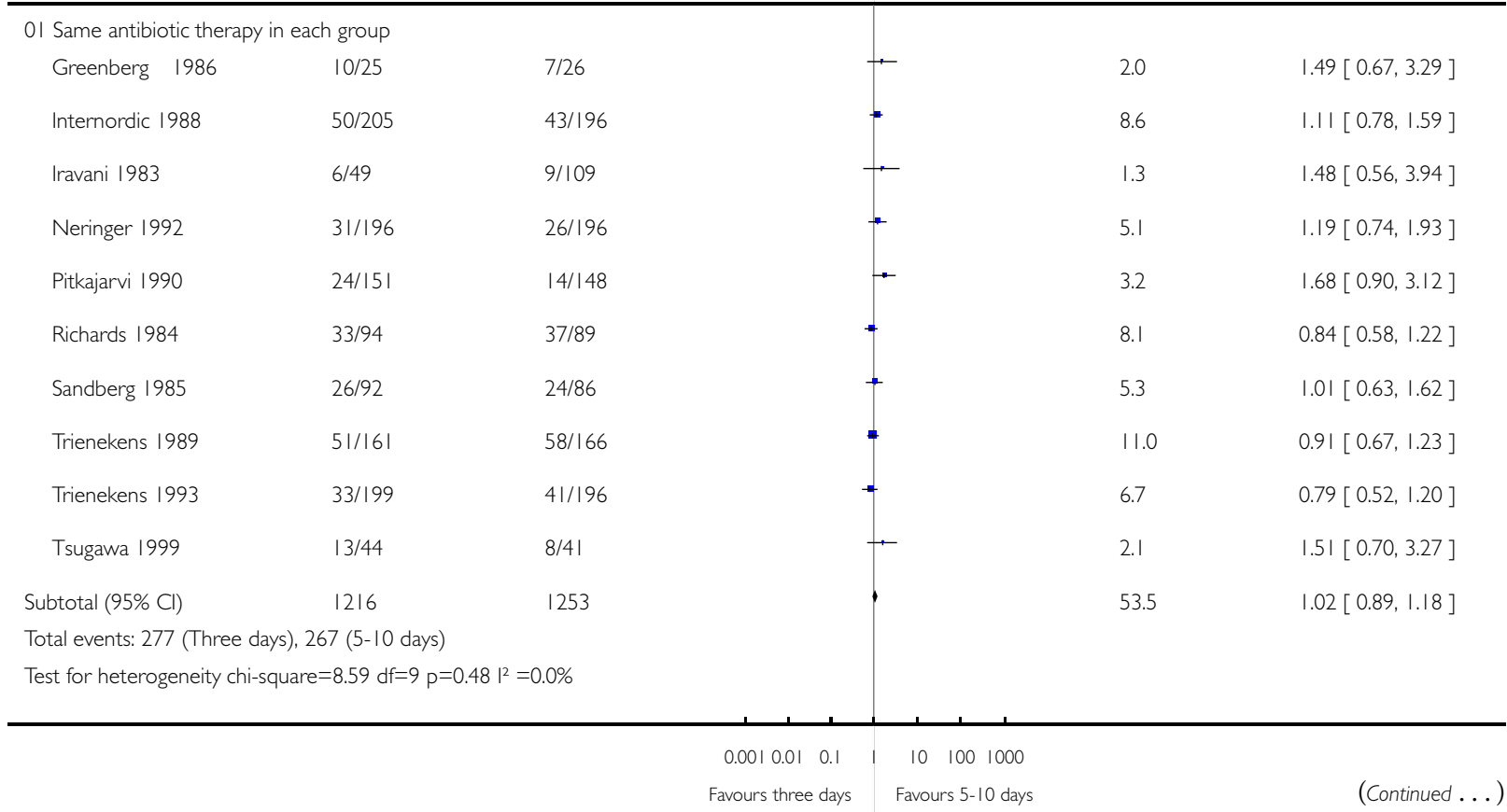

Duration of antibacterial treatment for uncomplicated urinary tract infection in women (Review) 


\begin{tabular}{|c|c|c|c|c|c|}
\hline Study & $\begin{array}{c}\text { Three days } \\
\mathrm{n} / \mathrm{N}\end{array}$ & $\begin{array}{l}5-10 \text { days } \\
n / N\end{array}$ & $\begin{array}{l}\text { Relative Risk (Random) } \\
\qquad 95 \% \mathrm{Cl}\end{array}$ & $\begin{array}{l}\text { Weight } \\
(\%)\end{array}$ & $\begin{array}{c}\text { Relative Risk (Random) } \\
\qquad 95 \% \mathrm{Cl}\end{array}$ \\
\hline \multicolumn{6}{|c|}{ Test for overall effect $z=0.31 \quad p=0.8$} \\
\hline \multicolumn{6}{|c|}{02 Different antibiotic therapy in each group } \\
\hline Cox 1992 & ||$/ 8 \mid$ & $23 / 82$ & $\rightarrow$ & 2.9 & $0.48[0.25,0.93]$ \\
\hline Figueroa 1999 & $1 / 20$ & 0/20 & | & 0.1 & $3.00[0.13,69.52]$ \\
\hline Guibert 1997 & $46 / 212$ & $55 / 209$ & $*$ & 9.3 & $0.82[0.59,1.16]$ \\
\hline Henry 1999 & $49 / 394$ & $48 / 386$ & $*$ & 8.0 & $1.00[0.69,1.45]$ \\
\hline Iravani 1999 & $79 / 239$ & | $45 / 474$ & 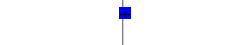 & 17.3 & $1.08[0.86,1.35]$ \\
\hline Stein 1987 & $3 / 74$ & $0 / 81$ & 7 & 0.2 & $7.65[0.40,145.73]$ \\
\hline Stein 1992 & $39 / 142$ & $47 / 146$ & $*$ & 8.6 & $0.85[0.60,1.22]$ \\
\hline Subtotal $(95 \% \mathrm{Cl})$ & 1162 & 1398 & • & 46.5 & $0.91[0.74,1.12]$ \\
\hline \multicolumn{6}{|c|}{ Total events: 228 (Three days), 318 (5-10 days) } \\
\hline \multicolumn{6}{|c|}{ Test for heterogeneity chi-square $=8.90 \mathrm{df}=6 \mathrm{p}=0.18 \mathrm{I}^{2}=32.6 \%$} \\
\hline \multicolumn{6}{|c|}{ Test for overall effect $z=0.89 \quad p=0.4$} \\
\hline Total $(95 \% \mathrm{Cl})$ & 2378 & 2651 & ' & 100.0 & $0.98[0.88,1.10]$ \\
\hline \multicolumn{6}{|c|}{ Total events: 505 (Three days), 585 (5-10 days) } \\
\hline \multicolumn{6}{|c|}{ Test for heterogeneity chi-square $=18.08 \mathrm{df}=16 \mathrm{p}=0.32 \mathrm{l}^{2}=11.5 \%$} \\
\hline Test for overall effect $z=0.30$ & $=0.8$ & & & & \\
\hline
\end{tabular}

$0.0010 .010 .1 \quad 1 \quad 10 \quad 100 \quad 1000$

Favours three days Favours 5-10 days 
Analysis 01.03. Comparison 01 Three days versus 5-10 day antibiotic therapy, Outcome 03 Long-term symptomatic failure (4- 10 weeks from end of treatment)

Review: Duration of antibacterial treatment for uncomplicated urinary tract infection in women

Comparison: 01 Three days versus 5-10 day antibiotic therapy

Outcome: 03 Long-term symptomatic failure (4-10 weeks from end of treatment)

\begin{tabular}{|c|c|c|c|c|c|}
\hline Study & $\begin{array}{c}\text { Three days } \\
n / N\end{array}$ & $\begin{array}{c}\text { 5- } 10 \text { days } \\
\mathrm{n} / \mathrm{N}\end{array}$ & $\begin{array}{l}\text { Relative Risk (Random) } \\
\qquad 95 \% \mathrm{Cl}\end{array}$ & $\begin{array}{c}\text { Weight } \\
(\%)\end{array}$ & $\begin{array}{c}\text { Relative Risk (Random) } \\
95 \% \mathrm{Cl}\end{array}$ \\
\hline \multicolumn{6}{|c|}{ 0I Same antibiotic therapy in each group } \\
\hline Internordic 1988 & $39 / 193$ & $21 / 180$ & - & 8.4 & $1.73[1.06,2.83]$ \\
\hline Neringer 1992 & $55 / 196$ & $53 / 196$ & + & 16.7 & $1.04[0.75,1.43]$ \\
\hline Plipo 1990 & $20 / 164$ & $15 / 163$ & 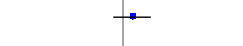 & 5.3 & $1.33[0.70,2.50]$ \\
\hline Pitkajarvi 1990 & $41 / 145$ & $28 / 133$ & - & 11.0 & $1.34[0.88,2.04]$ \\
\hline Sandberg 1985 & $35 / 77$ & $28 / 65$ & $\rightarrow$ & 13.4 & $1.06[0.73,1.53]$ \\
\hline Trienekens 1989 & $19 / 116$ & $17 / 123$ & + & 5.8 & $1.19[0.65,2.17]$ \\
\hline Trienekens 1993 & $19 / 150$ & $28 / 155$ & $\rightarrow$ & 7.1 & $0.70[0.41,1.20]$ \\
\hline Tsugawa 1999 & $5 / 33$ & $1 / 32$ & + & 0.5 & $4.85[0.60,39.25]$ \\
\hline Subtotal $(95 \% \mathrm{Cl})$ & 1074 & 1047 & 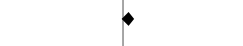 & 68.2 & $1.16[0.95,1.42]$ \\
\hline \multicolumn{6}{|c|}{ Total events: 233 (Three days), 191 (5-10 days) } \\
\hline \multicolumn{6}{|c|}{ Test for heterogeneity chi-square $=9.13 \mathrm{df}=7 \mathrm{p}=0.24 \mathrm{I}^{2}=23.3 \%$} \\
\hline \multicolumn{6}{|c|}{ Test for overall effect $z=1.48 \quad p=0.1$} \\
\hline \multicolumn{6}{|c|}{02 Different antibiotic therapy in each group } \\
\hline Henry 1999 & $75 / 261$ & $82 / 280$ & 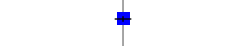 & 22.1 & $0.98[0.75,1.28]$ \\
\hline Iravani 1999 & $23 / 155$ & $52 / 324$ & $\rightarrow$ & 9.7 & $0.92[0.59,1.45]$ \\
\hline Subtotal $(95 \% \mathrm{Cl})$ & 416 & 604 & 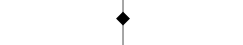 & 31.8 & $0.97[0.77,1.21]$ \\
\hline \multicolumn{6}{|c|}{ Total events: 98 (Three days), 134 (5-10 days) } \\
\hline \multicolumn{6}{|c|}{ Test for heterogeneity chi-square $=0.05 \mathrm{df}=\mid \mathrm{p}=0.82 \mathrm{I}^{2}=0.0 \%$} \\
\hline \multicolumn{6}{|c|}{ Test for overall effect $z=0.29 \quad p=0.8$} \\
\hline Total $(95 \% \mathrm{Cl})$ & 1490 & $|65|$ & - & 100.0 & $1.09[0.94,1.27]$ \\
\hline \multicolumn{6}{|c|}{ Total events: 33I (Three days), 325 (5-10 days) } \\
\hline \multicolumn{6}{|c|}{ Test for heterogeneity chi-square $=10.62 \mathrm{df}=9 \mathrm{p}=0.30 \mathrm{I}^{2}=15.3 \%$} \\
\hline Test for overall effect $z=1.13$ & $p=0.3$ & & & & \\
\hline
\end{tabular}

Favours three days Favours 5-10 days 


\section{Analysis 01.04. Comparison 0I Three days versus 5-10 day antibiotic therapy, Outcome 04 Long-term}

symptomatic failure - ITT (4-10 weeks from end of treatment)

Review: Duration of antibacterial treatment for uncomplicated urinary tract infection in women

Comparison: 01 Three days versus 5-10 day antibiotic therapy

Outcome: 04 Long-term symptomatic failure - ITT (4-10 weeks from end of treatment)

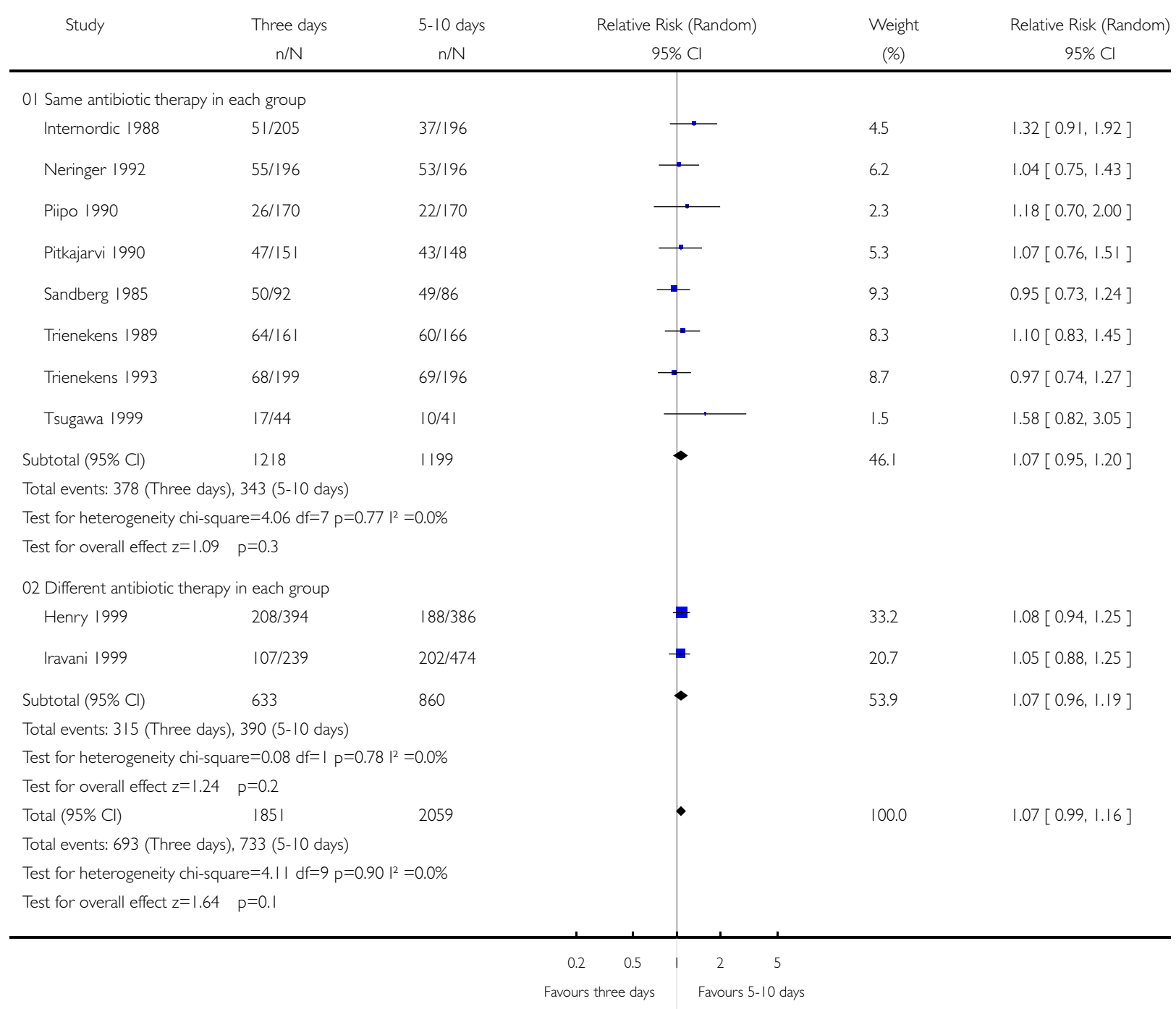

Duration of antibacterial treatment for uncomplicated urinary tract infection in women (Review) 


\section{Analysis 01.05. Comparison 01 Three days versus 5-10 day antibiotic therapy, Outcome 05 Short-term}

bacteriologic failure (2-15 days from end of treatment)

Review: Duration of antibacterial treatment for uncomplicated urinary tract infection in women

Comparison: 01 Three days versus 5-10 day antibiotic therapy

Outcome: 05 Short-term bacteriologic failure (2-15 days from end of treatment)

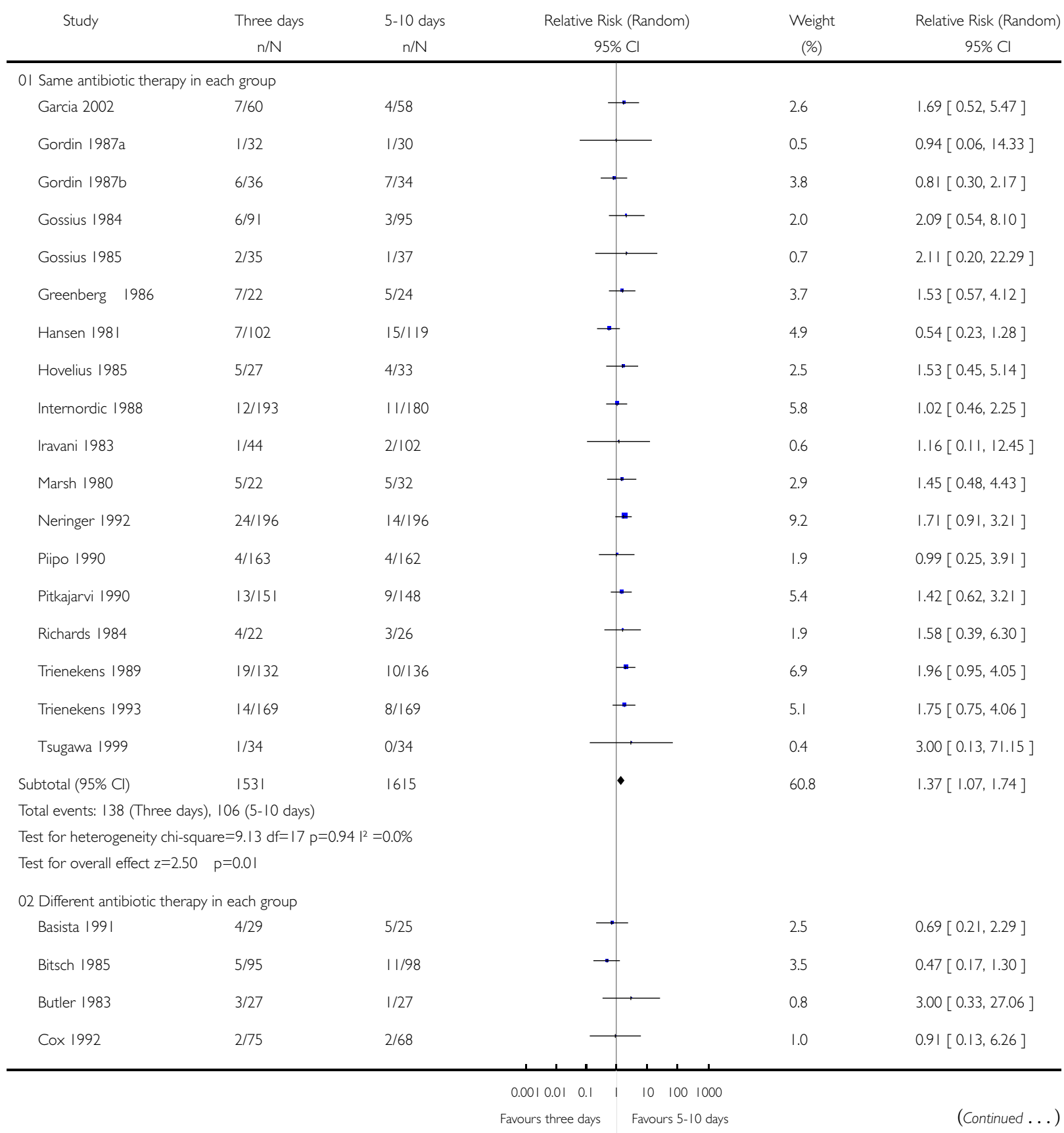

Duration of antibacterial treatment for uncomplicated urinary tract infection in women (Review) 


\begin{tabular}{|c|c|c|c|c|c|}
\hline Study & $\begin{array}{c}\text { Three days } \\
n / N\end{array}$ & $\begin{array}{l}5-10 \text { days } \\
n / N\end{array}$ & $\begin{array}{l}\text { Relative Risk (Random) } \\
\qquad 95 \% \mathrm{Cl}\end{array}$ & $\begin{array}{l}\text { Weight } \\
(\%)\end{array}$ & $\begin{array}{c}\text { Relative Risk (Random) } \\
\qquad 95 \% \mathrm{Cl}\end{array}$ \\
\hline Figueroa 1999 & $1 / 20$ & 2/20 & \begin{tabular}{l|l}
$\longrightarrow$ \\
\end{tabular} & 0.7 & $0.50[0.05,5.08]$ \\
\hline Henry 1999 & 15/203 & 7/203 & 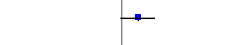 & 4.7 & $2.14[0.89,5.14]$ \\
\hline Hooton 1991 & $4 / 48$ & $2 / 44$ & $\longrightarrow$ & 1.3 & $1.83[0.35,9.52]$ \\
\hline Iravani 1999 & $20 / 168$ & $37 / 351$ & 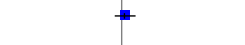 & 13.9 & $1.13[0.68,1.88]$ \\
\hline Menday 2000 & | 1//107 & $20 / 109$ & $\rightarrow$ & 7.7 & $0.56[0.28,1.11]$ \\
\hline Rapoport 1981 & $2 / 41$ & 2/34 & $\longrightarrow$ & 1.0 & $0.83[0.12,5.58]$ \\
\hline Stein 1987 & $3 / 74$ & $0 / 81$ & + & 0.4 & $7.65[0.40,145.73]$ \\
\hline Stein 1992 & $3 / 115$ & $4 / 105$ & $\longrightarrow$ & 1.7 & $0.68[0.16,2.99]$ \\
\hline × Winwick 1981 & 0/29 & $0 / 26$ & & 0.0 & Not estimable \\
\hline Subtotal (95\% Cl) & 1031 & 1191 & $\bullet$ & 39.2 & $0.96[0.68,1.35]$ \\
\hline \multicolumn{6}{|c|}{ Total events: 73 (Three days), 93 (5-10 days) } \\
\hline \multicolumn{6}{|c|}{ Test for heterogeneity chi-square $=12.28 \mathrm{df}=1 \mid \mathrm{p}=0.34 \mathrm{I}^{2}=10.4 \%$} \\
\hline \multicolumn{6}{|c|}{ Test for overall effect $z=0.26 \quad p=0.8$} \\
\hline Total $(95 \% \mathrm{Cl})$ & 2562 & 2806 & - & 100.0 & $1.19[0.98,1.44]$ \\
\hline \multicolumn{6}{|c|}{ Total events: 21 I (Three days), 199 (5-10 days) } \\
\hline \multicolumn{6}{|c|}{ Test for heterogeneity chi-square $=24.54 \mathrm{df}=29 \mathrm{p}=0.70 \mathrm{I}^{2}=0.0 \%$} \\
\hline Test for overall effe & $=0.08$ & & & & \\
\hline
\end{tabular}




\section{Analysis 01.06. Comparison 0I Three days versus 5-10 day antibiotic therapy, Outcome 06 Short-term}

bacteriological failure by antiboitic class (same drug) (2- 15 days from end of treatment)

Review: Duration of antibacterial treatment for uncomplicated urinary tract infection in women

Comparison: 01 Three days versus 5-10 day antibiotic therapy

Outcome: 06 Short-term bacteriological failure by antiboitic class (same drug) (2-15 days from end of treatment)

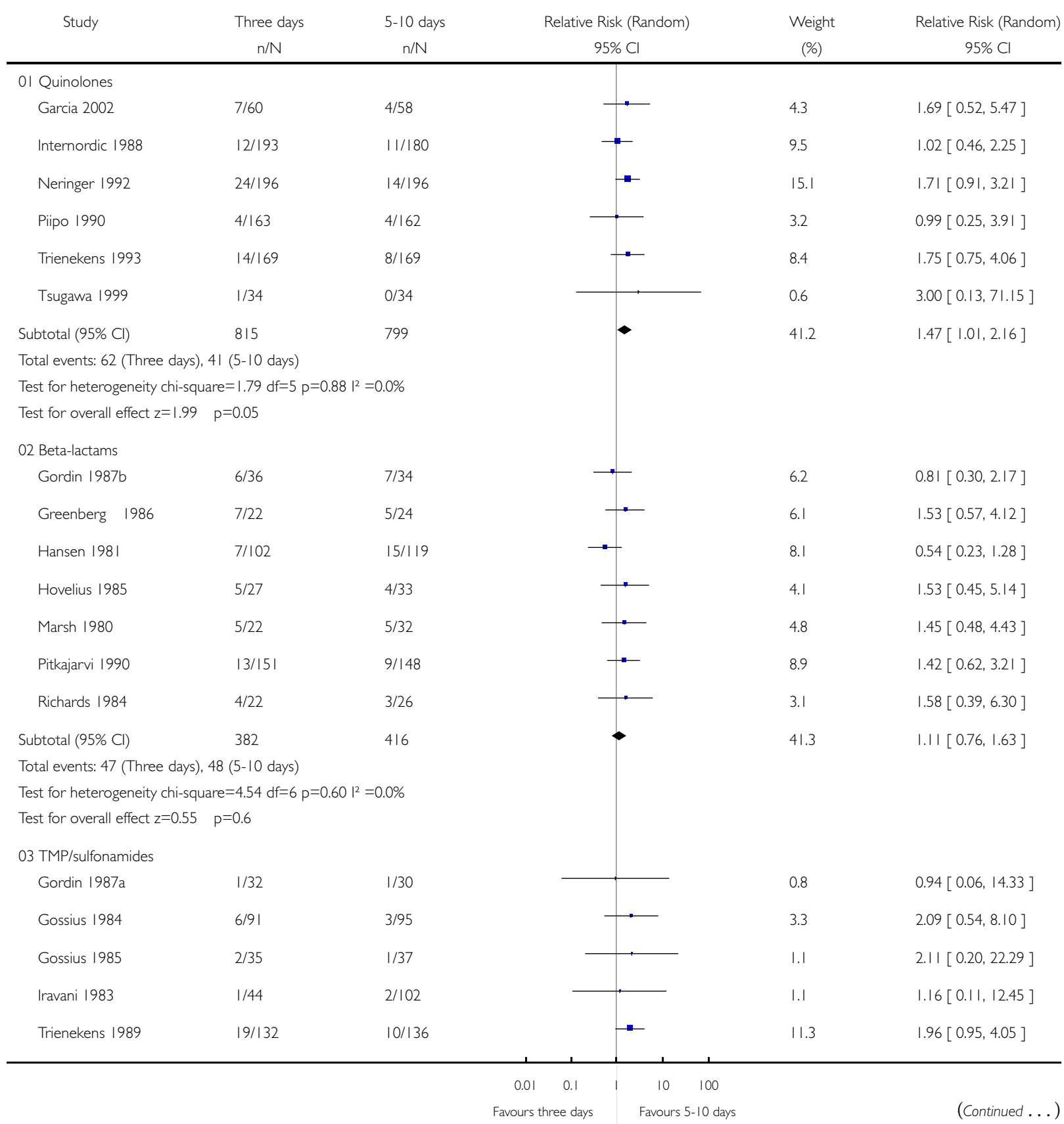

Duration of antibacterial treatment for uncomplicated urinary tract infection in women (Review) 


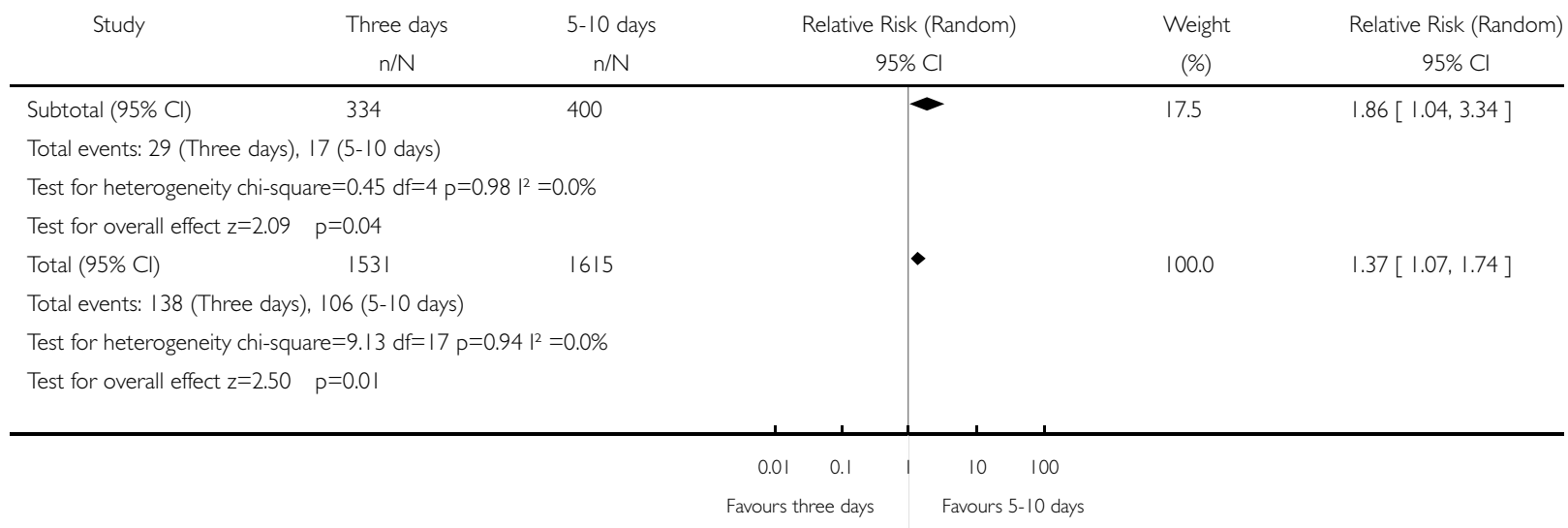

\section{Analysis 01.07. Comparison 0I Three days versus 5-10 day antibiotic therapy, Outcome 07 Short-term bacteriological failure - ITT (2-I5 days from end of treatment)}

Review: Duration of antibacterial treatment for uncomplicated urinary tract infection in women

Comparison: 01 Three days versus 5-10 day antibiotic therapy

Outcome: 07 Short-term bacteriological failure - ITT (2-15 days from end of treatment)

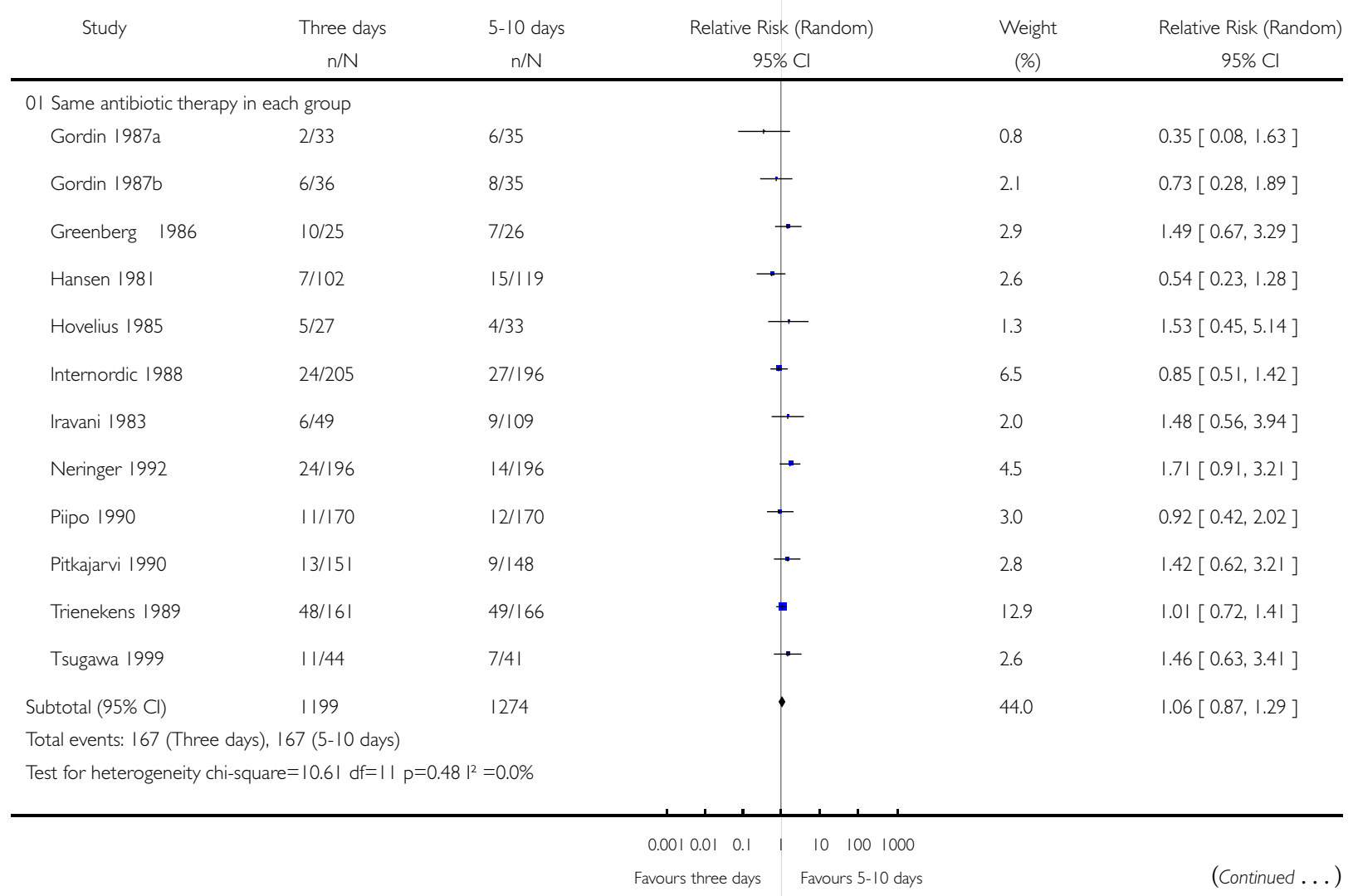

Duration of antibacterial treatment for uncomplicated urinary tract infection in women (Review) 


\begin{tabular}{|c|c|c|c|c|c|}
\hline & $n / N$ & $n / N$ & $95 \% \mathrm{Cl}$ & (\%) & $95 \% \mathrm{Cl}$ \\
\hline \multicolumn{6}{|c|}{ Test for overall effect $z=0.56 \quad p=0.6$} \\
\hline \multicolumn{6}{|c|}{02 Different antibiotic therapy in each group } \\
\hline Basista |99| & $12 / 37$ & $15 / 35$ & $\rightarrow$ & 4.9 & $0.76[0.41,1.38]$ \\
\hline Cox 1992 & $8 / 81$ & $16 / 82$ & $\rightarrow$ & 3.0 & $0.51[0.23,1.12]$ \\
\hline Figueroa 1999 & $1 / 20$ & $2 / 20$ & $\longrightarrow$ & 0.4 & $0.50[0.05,5.08]$ \\
\hline Henry 1999 & $89 / 277$ & $92 / 288$ & " & 19.7 & $1.01[0.79,1.28]$ \\
\hline Hooton 1991 & $5 / 49$ & $5 / 47$ & T & 1.4 & $0.96[0.30,3.10]$ \\
\hline Menday 2000 & $52 / 148$ & $74 / 163$ & - & 16.7 & $0.77[0.59,1.02]$ \\
\hline Stein 1987 & $3 / 74$ & $0 / 81$ & - & 0.2 & $7.65[0.40,145.73]$ \\
\hline Stein 1992 & $30 / 142$ & $45 / 146$ & - & 9.8 & $0.69[0.46,1.02]$ \\
\hline Subtotal $(95 \% \mathrm{Cl})$ & 828 & 862 & • & 56.0 & $0.83[0.70,0.98]$ \\
\hline \multicolumn{6}{|c|}{ Total events: 200 (Three days), 249 (5-10 days) } \\
\hline \multicolumn{6}{|c|}{ Test for heterogeneity chi-square $=7.58 \mathrm{df}=7 \mathrm{p}=0.37 \mathrm{I}^{2}=7.7 \%$} \\
\hline \multicolumn{6}{|c|}{ Test for overall effect $z=2.15 \quad p=0.03$} \\
\hline Total $(95 \% \mathrm{Cl})$ & 2027 & 2136 & ! & 100.0 & $0.92[0.80,1.06]$ \\
\hline \multicolumn{6}{|c|}{ Total events: 367 (Three days), 416 (5-10 days) } \\
\hline \multicolumn{6}{|c|}{ Test for heterogeneity chi-square $=21.52 \mathrm{df}=19 \mathrm{p}=0.31 \mathrm{I}^{2}=11.7 \%$} \\
\hline Test for overall effe & $=0.2$ & & & & \\
\hline
\end{tabular}




\section{Analysis 01.08. Comparison 0I Three days versus 5-10 day antibiotic therapy, Outcome 08 Long-term bacteriological failure (4- 10 weeks from end of treatment)}

Review: Duration of antibacterial treatment for uncomplicated urinary tract infection in women

Comparison: 01 Three days versus 5-10 day antibiotic therapy

Outcome: 08 Long-term bacteriological failure (4-10 weeks from end of treatment)

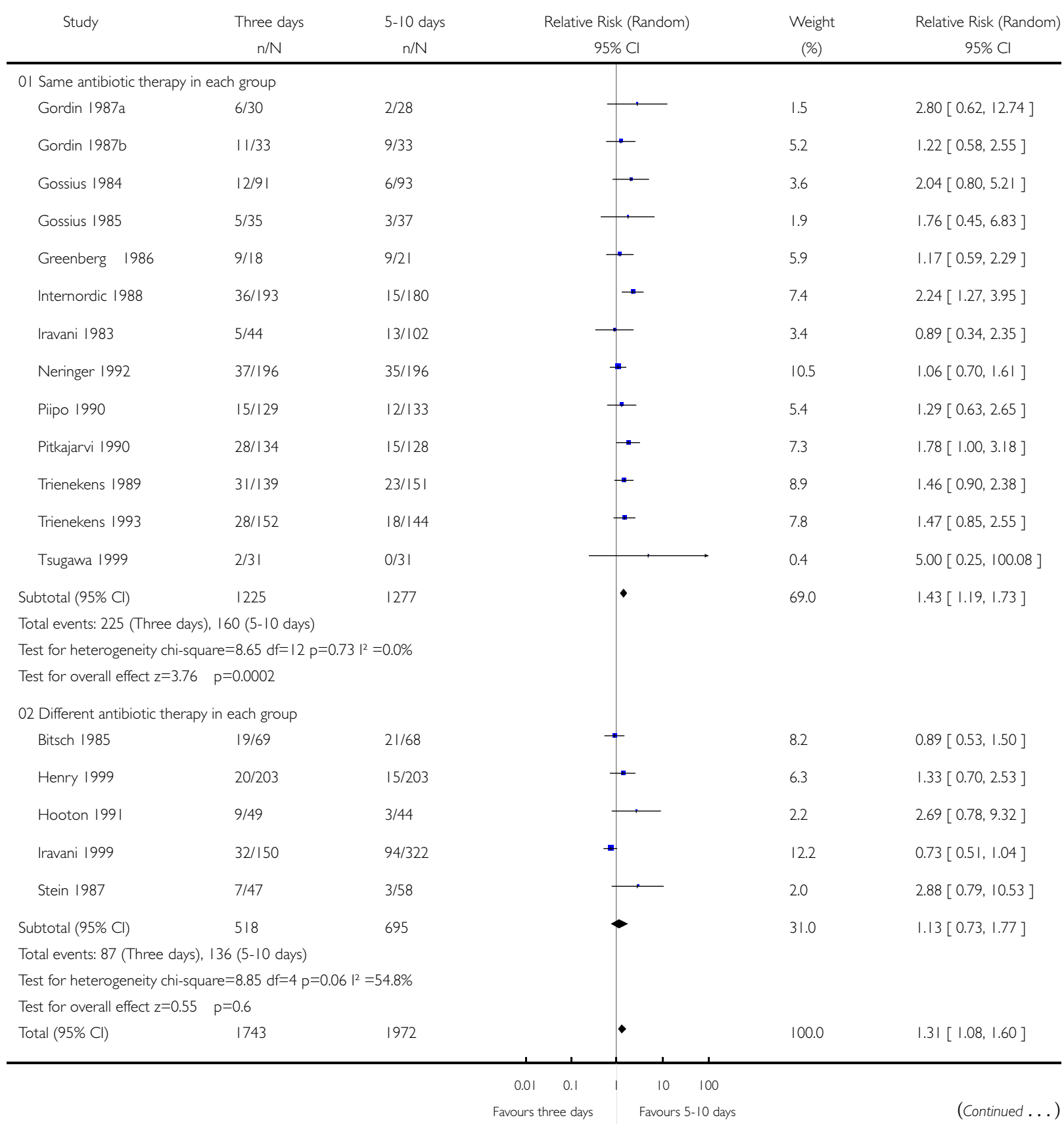

Duration of antibacterial treatment for uncomplicated urinary tract infection in women (Review) 


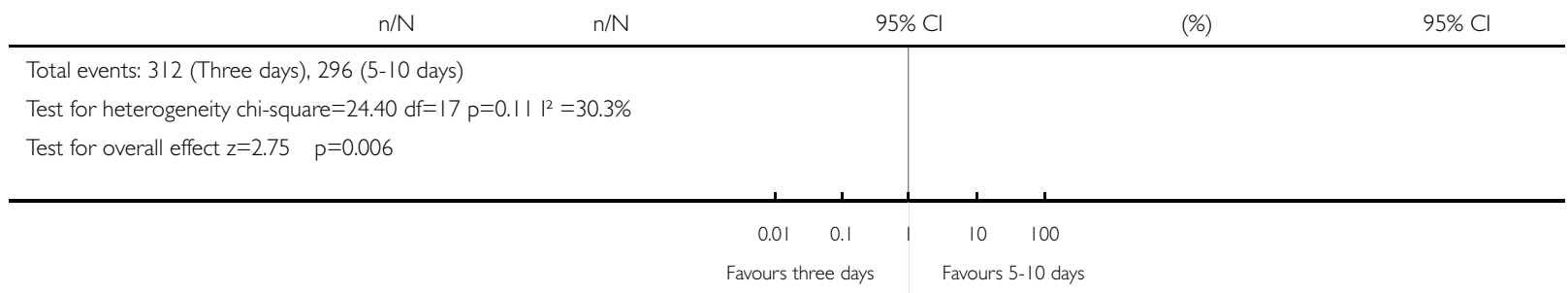

\section{Analysis 01.09. Comparison 0I Three days versus 5-10 day antibiotic therapy, Outcome 09 Long-term bacteriological failure by antibiotic class (same drug) (4-10 weeks from end of treatment)}

Review: Duration of antibacterial treatment for uncomplicated urinary tract infection in women

Comparison: 0 I Three days versus 5-10 day antibiotic therapy

Outcome: 09 Long-term bacteriological failure by antibiotic class (same drug) (4- 10 weeks from end of treatment)

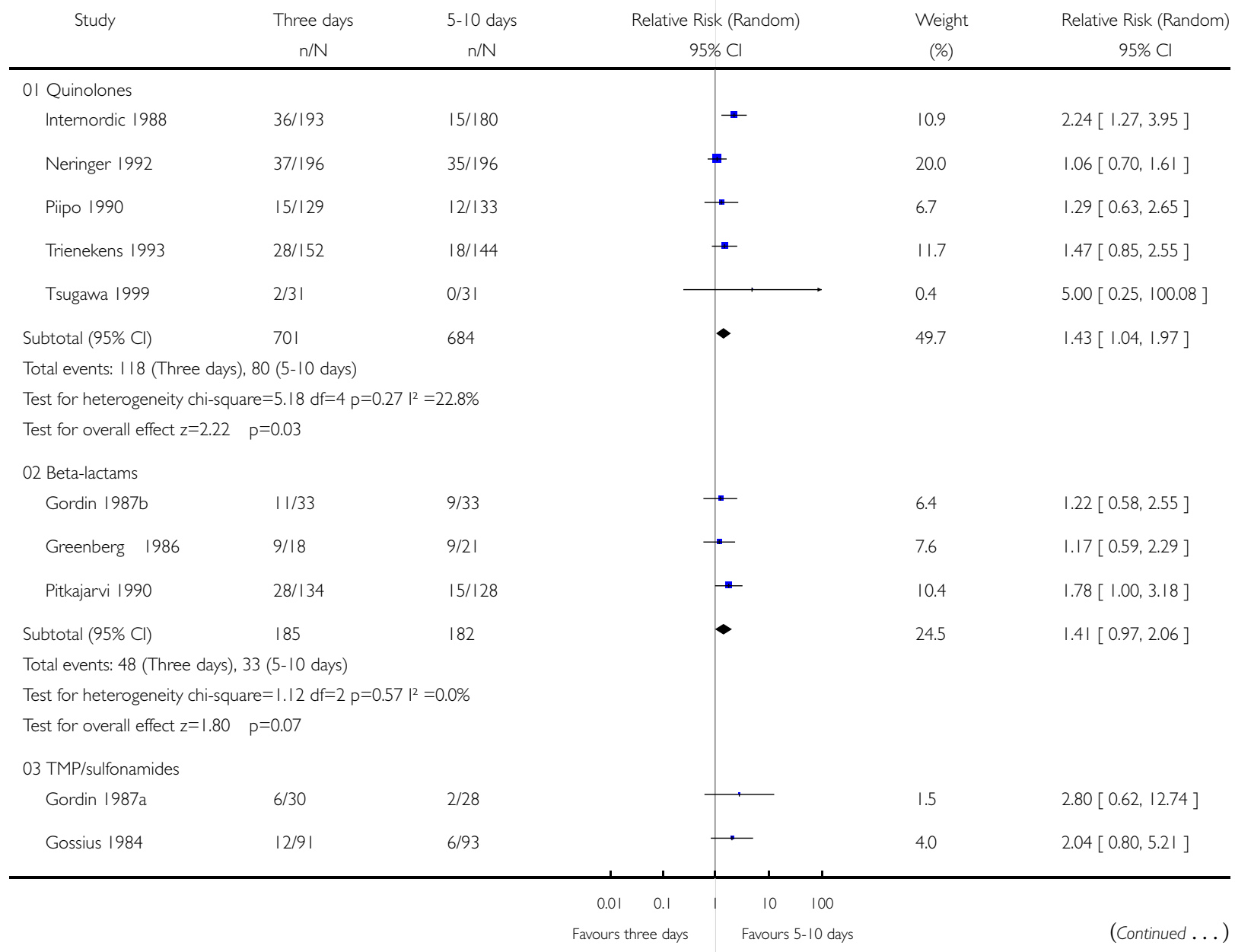

Duration of antibacterial treatment for uncomplicated urinary tract infection in women (Review) 


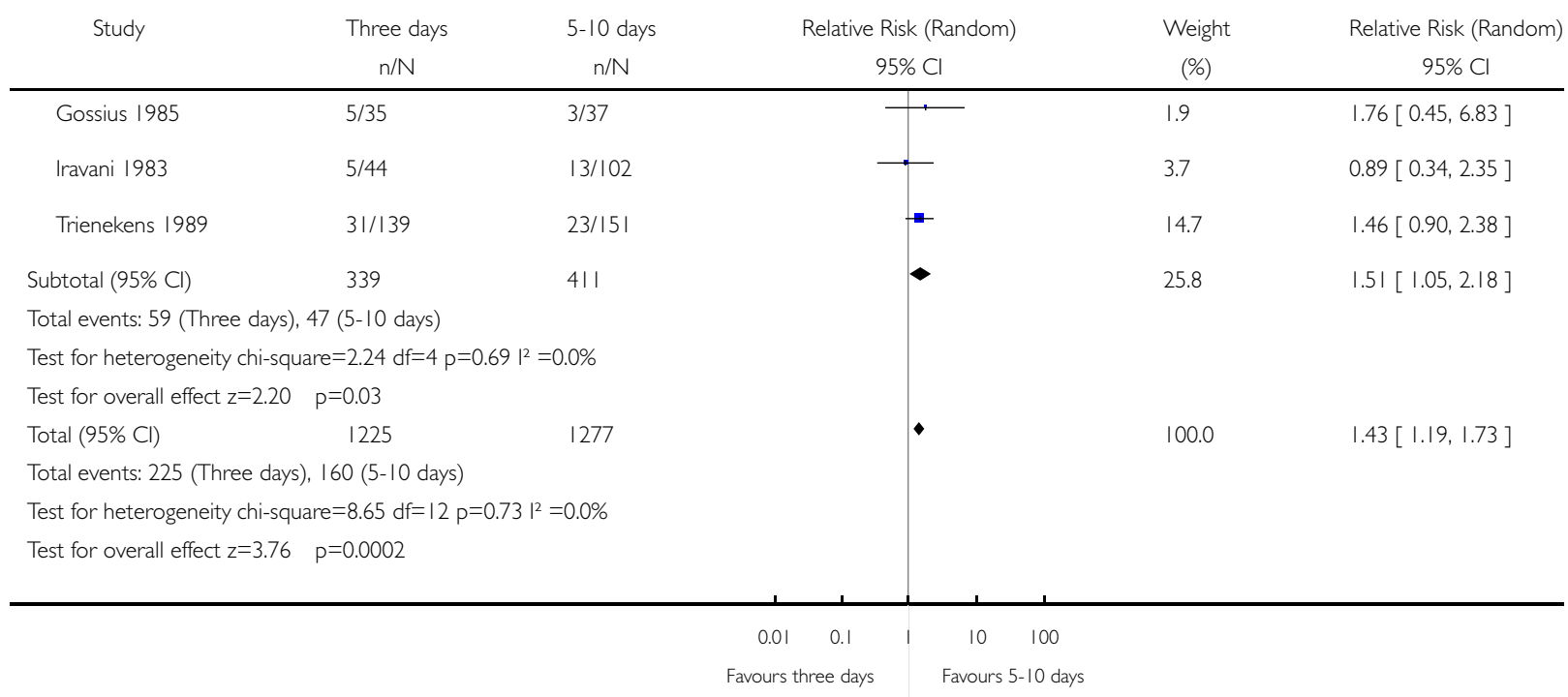

\section{Analysis 01.10. Comparison 01 Three days versus 5-10 day antibiotic therapy, Outcome 10 Long-term bacteriological failure - ITT (4-10 weeks from end of treatment)}

Review: Duration of antibacterial treatment for uncomplicated urinary tract infection in women

Comparison: 01 Three days versus 5-10 day antibiotic therapy

Outcome: 10 Long-term bacteriological failure - ITT (4-10 weeks from end of treatment)

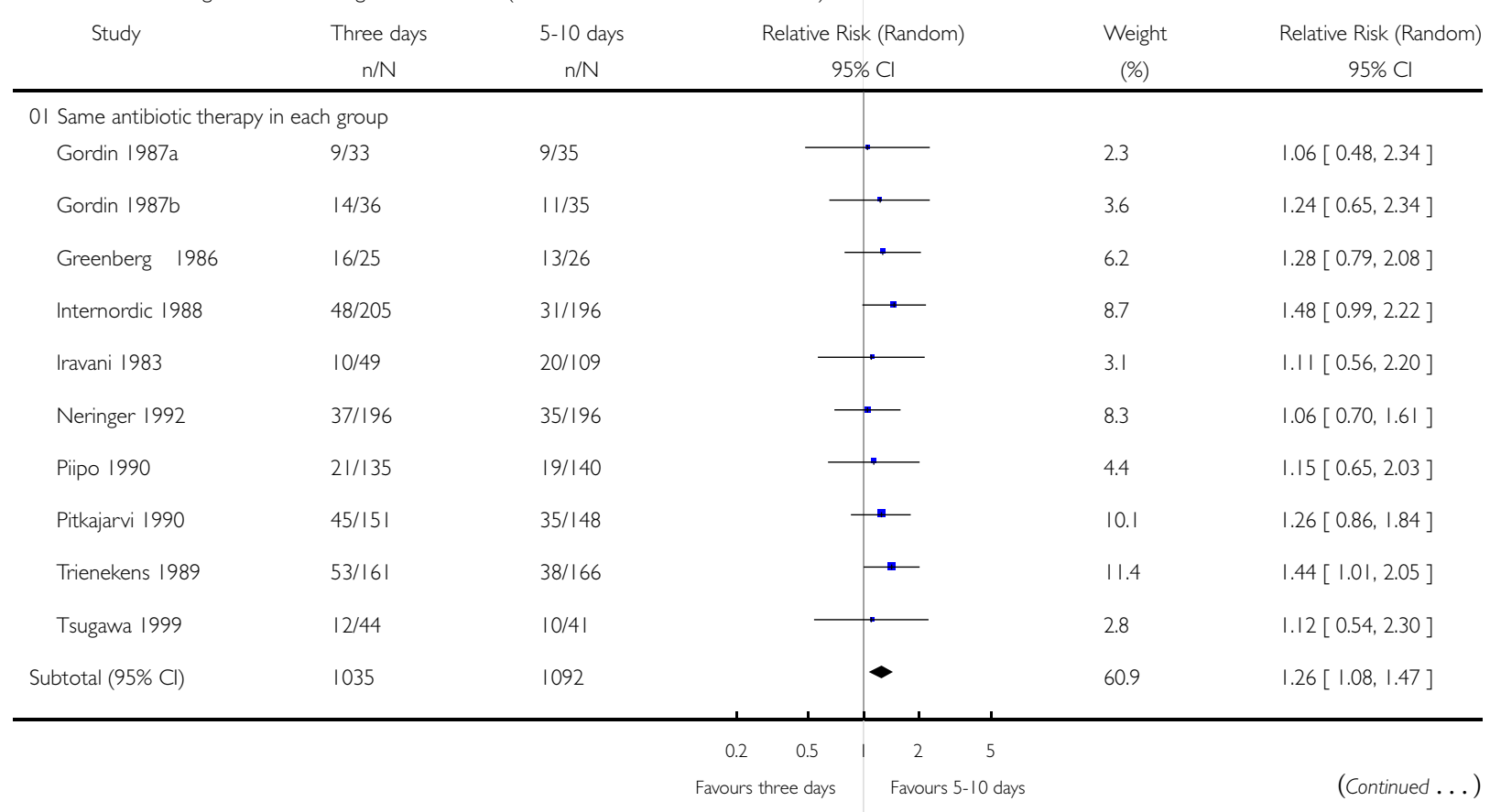

Duration of antibacterial treatment for uncomplicated urinary tract infection in women (Review) 


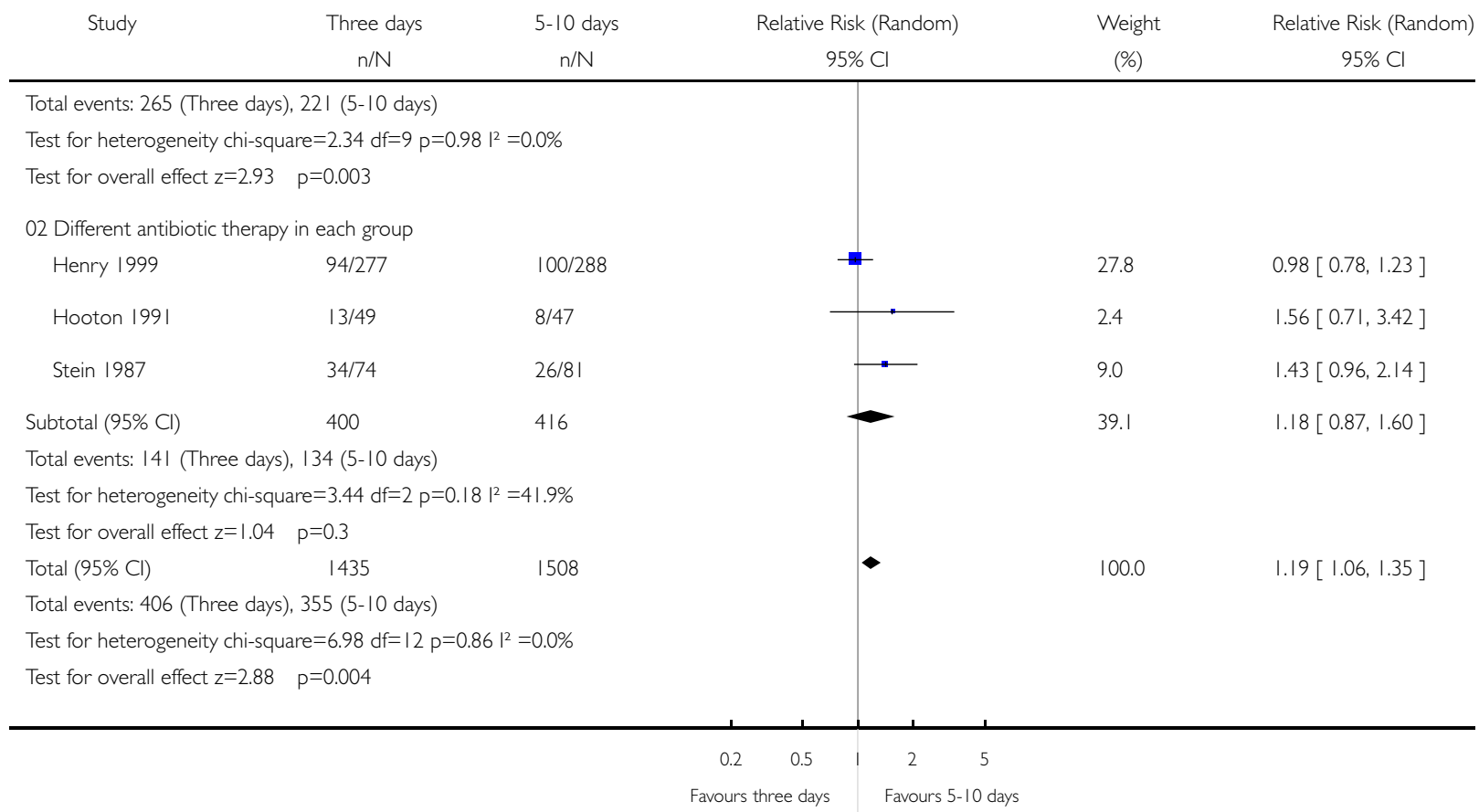

\section{Analysis 0I.I I. Comparison 0I Three days versus 5-10 day antibiotic therapy, Outcome II Long-term bacteriological failure - ITT by antibiotic class (same drug) (4-10 weeks from end of treatment)}

Review: Duration of antibacterial treatment for uncomplicated urinary tract infection in women

Comparison: 01 Three days versus 5-10 day antibiotic therapy

Outcome: II Long-term bacteriological failure - ITT by antibiotic class (same drug) (4-I 0 weeks from end of treatment)

$$
\text { Study Three days } \quad 5 \text { - } 10 \text { days } \quad \text { Relative Risk (Random) Relative Risk (Random) }
$$

$\mathrm{n} / \mathrm{N} \quad \mathrm{n} / \mathrm{N} \quad 95 \% \mathrm{C}$

(\%)

$95 \% \mathrm{Cl}$

\begin{tabular}{|c|c|c|}
\hline \multicolumn{3}{|l|}{ OI Quinolones } \\
\hline Internordic 1988 & $48 / 205$ & $31 / 196$ \\
\hline Neringer 1992 & $37 / 196$ & $35 / 196$ \\
\hline Piipo 1990 & $21 / 135$ & $19 / 140$ \\
\hline Tsugawa 1999 & $12 / 44$ & $|0 / 4|$ \\
\hline Subtotal $(95 \% \mathrm{Cl})$ & 580 & 573 \\
\hline \multicolumn{3}{|c|}{ Total events: I I 8 (Three days), 95 (5- 10 days) } \\
\hline \multicolumn{3}{|c|}{ Test for heterogeneity chi-square $=1.42 \mathrm{df}=3 \mathrm{p}=0.70 \mathrm{I}^{2}=0.0 \%$} \\
\hline Test for overall effect & $p=0.1$ & \\
\hline
\end{tabular}

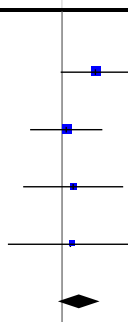

14.4

13.6

7.2

4.5

39.8

(Continued ... ) 


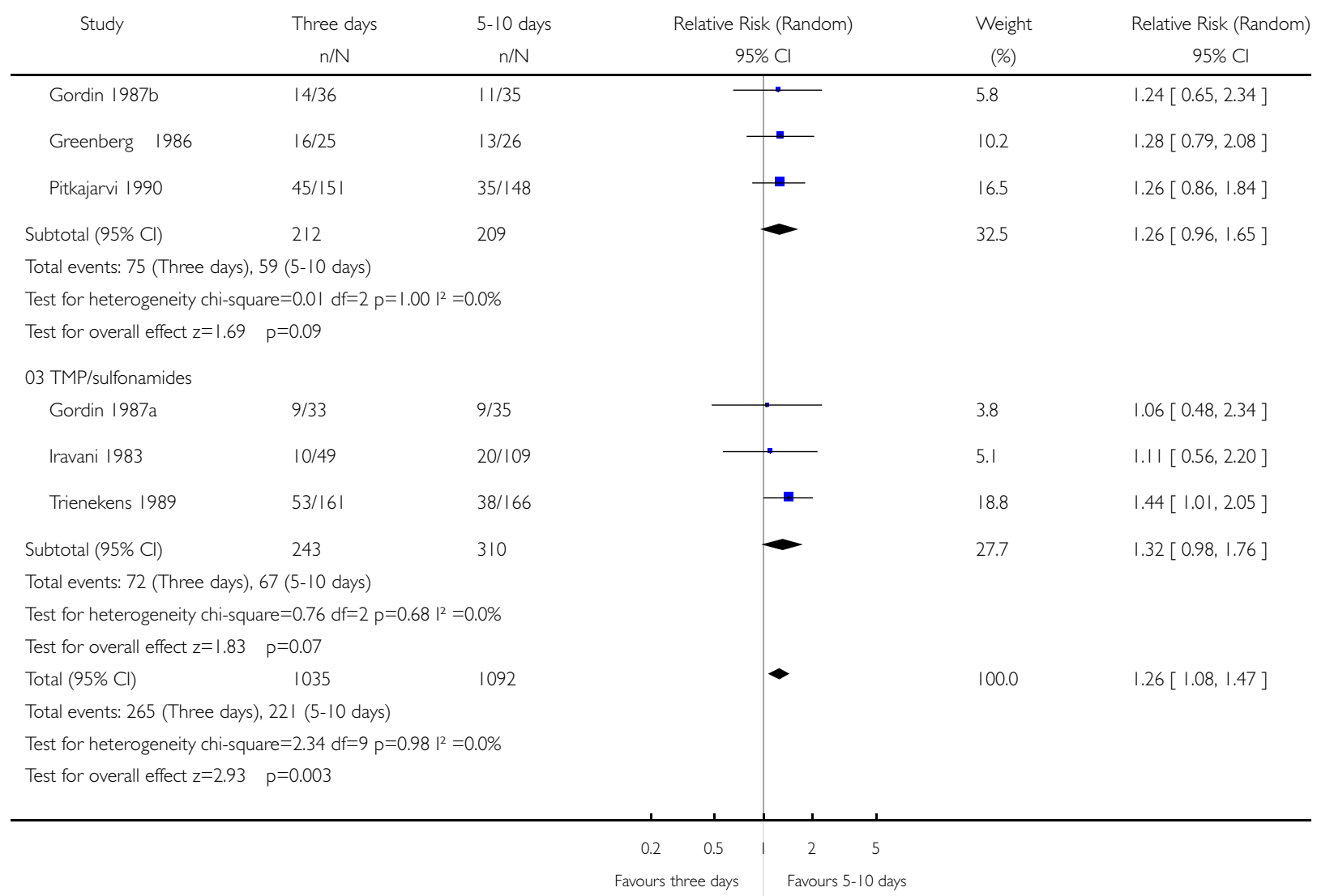


Analysis 0I.12. Comparison 01 Three days versus 5-10 day antibiotic therapy, Outcome I 2 Patients with any adverse effects during treatment

Review: Duration of antibacterial treatment for uncomplicated urinary tract infection in women

Comparison: 01 Three days versus 5-10 day antibiotic therapy

Outcome: 12 Patients with any adverse effects during treatment

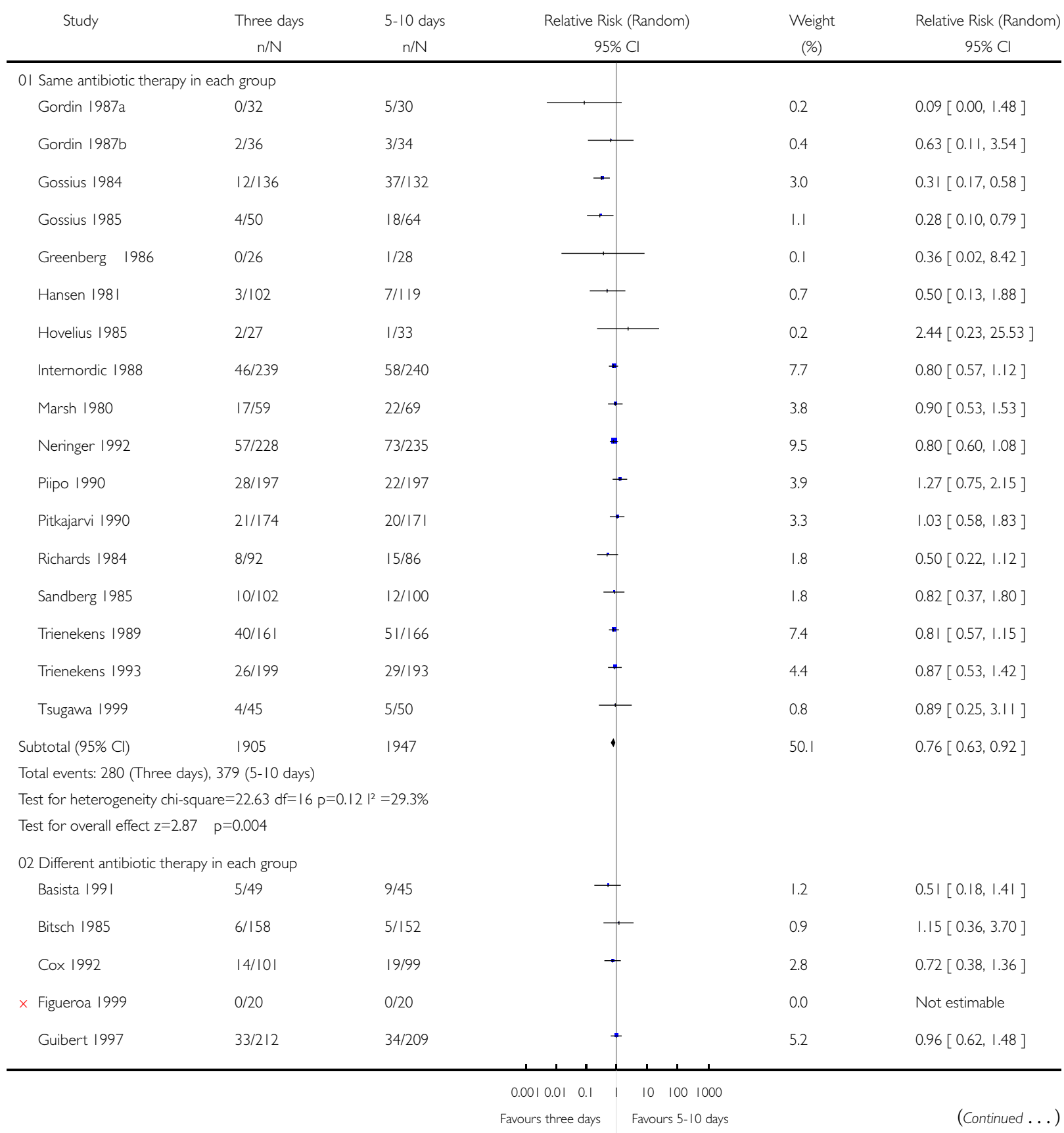

Duration of antibacterial treatment for uncomplicated urinary tract infection in women (Review) 


\begin{tabular}{|c|c|c|c|c|c|}
\hline Study & $\begin{array}{c}\text { Three days } \\
n / N\end{array}$ & $\begin{array}{l}5-10 \text { days } \\
n / N\end{array}$ & $\begin{array}{c}\text { Relative Risk (Random) } \\
\qquad 95 \% \mathrm{Cl}\end{array}$ & $\begin{array}{l}\text { Weight } \\
(\%)\end{array}$ & $\begin{array}{c}\text { Relative Risk (Random) } \\
\qquad 95 \% \mathrm{Cl}\end{array}$ \\
\hline Henry 1999 & $119 / 394$ & 106/386 & 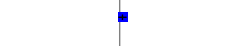 & 13.3 & $1.10[0.88,1.37]$ \\
\hline Hooton 1991 & $16 / 49$ & $19 / 47$ & + & 3.8 & $0.81[0.47,1.37]$ \\
\hline Iravani 1999 & $68 / 239$ & 170/474 & - & 12.5 & $0.79[0.63,1.00]$ \\
\hline Menday 2000 & $13 / 219$ & $16 / 221$ & + & 2.3 & $0.82[0.40,1.66]$ \\
\hline Stein 1987 & $15 / 109$ & $15 / 100$ & + & 2.6 & $0.92[0.47,1.78]$ \\
\hline Stein 1992 & $24 / 197$ & $31 / 207$ & $\rightarrow$ & 4.3 & $0.81[0.50,1.34]$ \\
\hline Winwick 1981 & $6 / 30$ & $6 / 28$ & 工 & 1.2 & $0.93[0.34,2.56]$ \\
\hline Subtotal $(95 \% \mathrm{Cl})$ & 1777 & 1988 & ' & 49.9 & $0.90[0.80,1.03]$ \\
\hline \multicolumn{6}{|c|}{ Total events: 319 (Three days), 430 (5-10 days) } \\
\hline \multicolumn{6}{|c|}{ Test for heterogeneity chi-square $=6.59 \mathrm{df}=10 \mathrm{p}=0.76 \mathrm{I}^{2}=0.0 \%$} \\
\hline \multicolumn{6}{|c|}{ Test for overall effect $z=1.53 \quad p=0.1$} \\
\hline Total $(95 \% \mathrm{Cl})$ & 3682 & 3935 & 1 & 100.0 & $0.83[0.74,0.93]$ \\
\hline \multicolumn{6}{|c|}{ Total events: 599 (Three days), 809 (5-10 days) } \\
\hline \multicolumn{6}{|c|}{ Test for heterogeneity chi-square $=31.55 \mathrm{df}=27 \mathrm{p}=0.25 \mathrm{I}^{2}=14.4 \%$} \\
\hline \multicolumn{6}{|c|}{ Test for overall effect $z=3.30 \quad p=0.001$} \\
\hline
\end{tabular}

Analysis 01.13. Comparison 0I Three days versus 5-10 day antibiotic therapy, Outcome 13 Patients developed pyelonephritis

Review: Duration of antibacterial treatment for uncomplicated urinary tract infection in women

Comparison: 01 Three days versus 5-10 day antibiotic therapy

Outcome: 13 Patients developed pyelonephritis

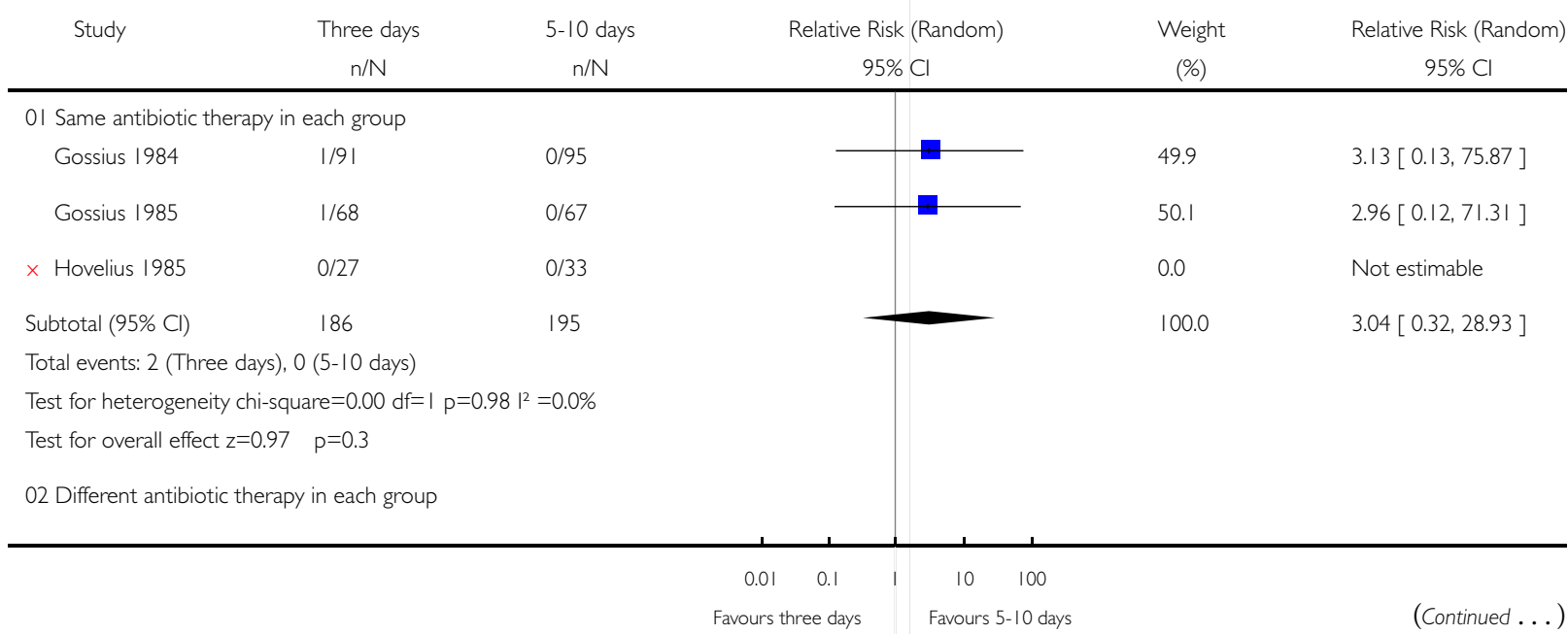


(... Continued)

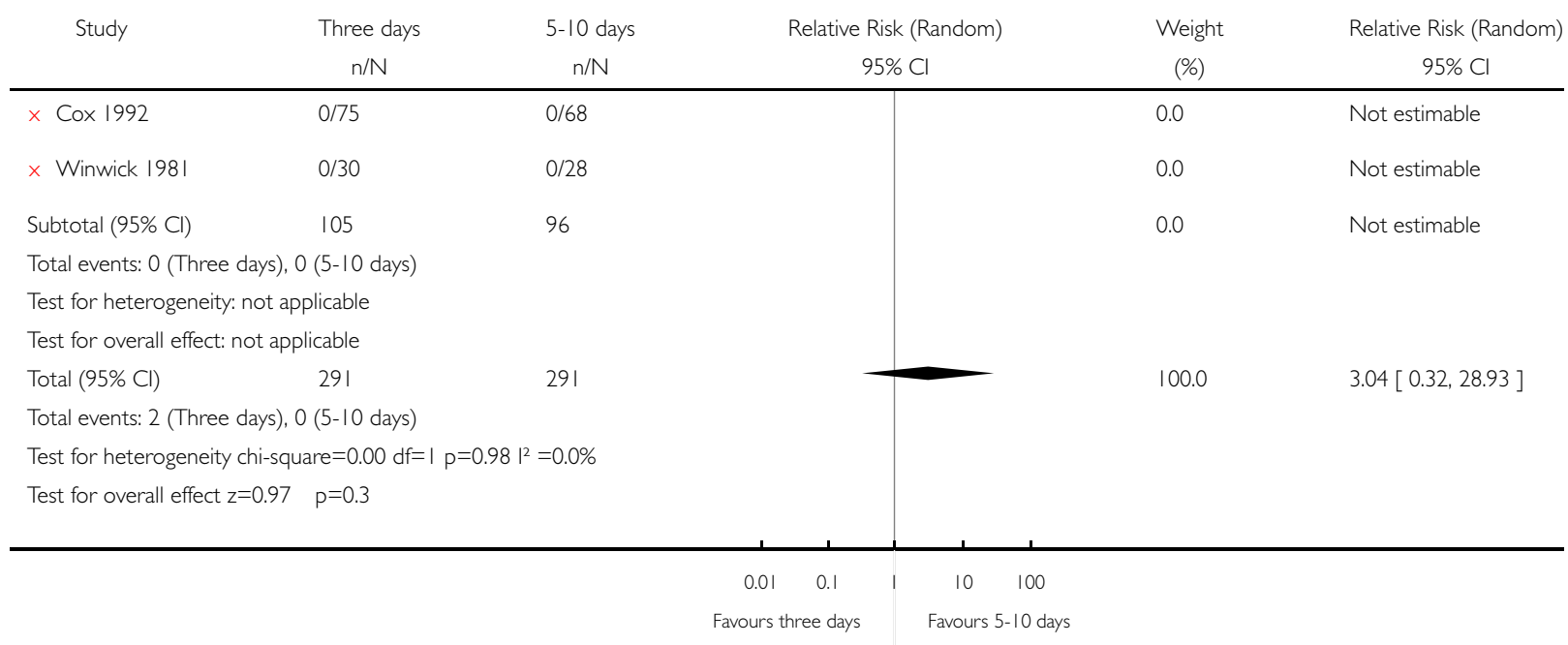

\section{Analysis 0I.14. Comparison 01 Three days versus 5-10 day antibiotic therapy, Outcome I4 Adverse effects requiring therapy discontinuation}

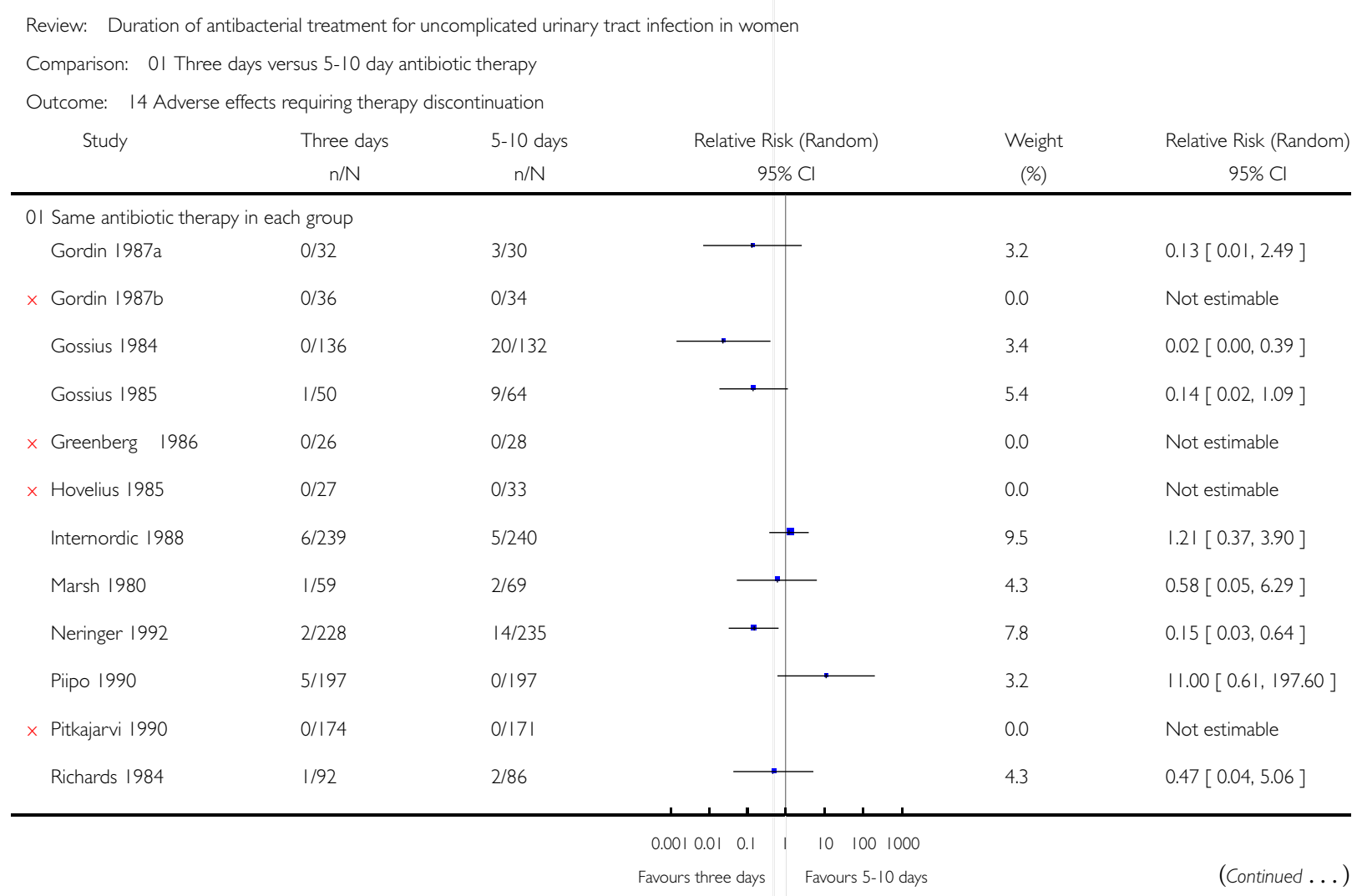




\begin{tabular}{|c|c|c|c|c|c|}
\hline Study & $\begin{array}{c}\text { Three days } \\
n / N\end{array}$ & $\begin{array}{c}\text { 5- } 10 \text { days } \\
n / N\end{array}$ & $\begin{array}{l}\text { Relative Risk (Random) } \\
\qquad 95 \% \mathrm{Cl}\end{array}$ & $\begin{array}{c}\text { Weight } \\
(\%)\end{array}$ & $\begin{array}{c}\text { Relative Risk (Random) } \\
95 \% \mathrm{Cl}\end{array}$ \\
\hline Sandberg 1985 & $0 / 102$ & $2 / 100$ & $\cdot$ & 3.0 & $0.20[0.01,4.03]$ \\
\hline Subtotal $(95 \% \mathrm{Cl})$ & 1398 & 1419 & - & 44.0 & $0.35[0.12,0.98]$ \\
\hline \multicolumn{6}{|c|}{ Total events: 16 (Three days), 57 (5-10 days) } \\
\hline \multicolumn{6}{|c|}{ Test for heterogeneity chi-square $=16.56 \mathrm{df}=8 \mathrm{p}=0.04 \mathrm{I}^{2}=51.7 \%$} \\
\hline \multicolumn{6}{|c|}{ Test for overall effect $z=2.01 \quad p=0.04$} \\
\hline \multicolumn{6}{|c|}{02 Different antibiotic therapy in each group } \\
\hline Bitsch 1985 & $1 / 158$ & $0 / 152$ & & 2.7 & $2.89[0.12,70.32]$ \\
\hline Butler 1983 & $0 / 59$ & $|/ 5|$ & - & 2.7 & $0.29[0.01,6.94]$ \\
\hline Cox 1992 & $0 / 101$ & 3/99 & & 3.1 & $0.14[0.01,2.68]$ \\
\hline × Figueroa 1999 & $0 / 20$ & $0 / 20$ & & 0.0 & Not estimable \\
\hline Henry 1999 & $17 / 394$ & $10 / 386$ & - & 12.2 & $1.67[0.77,3.59]$ \\
\hline Hooton 1991 & $0 / 49$ & $1 / 47$ & {[} & 2.8 & $0.32[0.01,7.66]$ \\
\hline Iravani 1999 & $3 / 239$ & $18 / 474$ & $\rightarrow$ & 9.3 & $0.33[0.10,1.11]$ \\
\hline Menday 2000 & $4 / 219$ & $4 / 221$ & $\rightarrow$ & 8.3 & $1.01[0.26,3.98]$ \\
\hline Stein 1987 & $2 / 109$ & $4 / 100$ & $\longrightarrow$ & 6.8 & $0.46[0.09,2.45]$ \\
\hline Stein 1992 & $3 / 197$ & $5 / 207$ & - & 8.1 & $0.63[0.15,2.60]$ \\
\hline × Winwick 1981 & $0 / 30$ & $0 / 28$ & & 0.0 & Not estimable \\
\hline Subtotal $(95 \% \mathrm{Cl})$ & 1575 & 1785 & $\bullet$ & 56.0 & $0.78[0.45,1.34]$ \\
\hline \multicolumn{6}{|c|}{ Total events: 30 (Three days), 46 (5-10 days) } \\
\hline \multicolumn{6}{|c|}{ Test for heterogeneity chi-square $=8.92 \mathrm{df}=8 \mathrm{p}=0.35 \mathrm{I}^{2}=10.4 \%$} \\
\hline \multicolumn{6}{|c|}{ Test for overall effect $z=0.91 \quad p=0.4$} \\
\hline Total $(95 \% \mathrm{Cl})$ & 2973 & 3204 & $\bullet$ & 100.0 & $0.51[0.28,0.91]$ \\
\hline \multicolumn{6}{|c|}{ Total events: 46 (Three days), 103 (5-10 days) } \\
\hline \multicolumn{6}{|c|}{ Test for heterogeneity chi-square $=29.30 \mathrm{df}=17 \mathrm{p}=0.03 \mathrm{I}^{2}=42.0 \%$} \\
\hline Test for overall effe & $=0.02$ & & & & \\
\hline
\end{tabular}

$0.0010 .010 .1 \quad 1 \quad 10 \quad 100 \quad 1000$

Favours three days Favours 5-10 days 
Analysis 0I.I5. Comparison 01 Three days versus 5-10 day antibiotic therapy, Outcome I5 Gastrointestinal adverse effects

Review: Duration of antibacterial treatment for uncomplicated urinary tract infection in women

Comparison: 01 Three days versus 5-10 day antibiotic therapy

Outcome: 15 Gastrointestinal adverse effects

\begin{tabular}{|c|c|c|c|c|c|}
\hline Study & $\begin{array}{c}\text { Three days } \\
\mathrm{n} / \mathrm{N}\end{array}$ & $\begin{array}{c}\text { 5- } 10 \text { days } \\
n / N\end{array}$ & $\begin{array}{l}\text { Relative Risk (Random) } \\
95 \% \mathrm{Cl}\end{array}$ & $\begin{array}{c}\text { Weight } \\
(\%)\end{array}$ & $\begin{array}{c}\text { Relative Risk (Random) } \\
95 \% \mathrm{Cl}\end{array}$ \\
\hline \multicolumn{6}{|c|}{ OI Same antibiotic therapy in each group } \\
\hline Gordin 1987a & 0/32 & $1 / 30$ & & 0.3 & $0.31[0.01,7.40]$ \\
\hline$\times$ Gordin 1987b & $0 / 36$ & $0 / 34$ & & 0.0 & Not estimable \\
\hline Gossius 1984 & $6 / 136$ & $11 / 132$ & $\longrightarrow$ & 3.5 & $0.53[0.20,1.39]$ \\
\hline Gossius 1985 & $3 / 50$ & $7 / 64$ & $\longrightarrow$ & 2.0 & $0.55[0.15,2.01]$ \\
\hline × Greenberg 1986 & $0 / 26$ & $0 / 28$ & & 0.0 & Not estimable \\
\hline Hansen 1981 & $3 / 102$ & $7 / 119$ & $\longrightarrow$ & 1.9 & $0.50[0.13,1.88]$ \\
\hline Internordic 1988 & $24 / 239$ & $26 / 240$ & $\rightarrow$ & 9.8 & $0.93[0.55,1.57]$ \\
\hline Marsh 1980 & $9 / 59$ & $13 / 69$ & $\rightarrow$ & 5.1 & $0.81[0.37,1.76]$ \\
\hline Neringer 1992 & $11 / 228$ & 19/235 & $\rightarrow$ & 5.9 & $0.60[0.29,1.23]$ \\
\hline Piipo 1990 & $17 / 197$ & $11 / 197$ & - & 5.7 & $1.55[0.74,3.21]$ \\
\hline Pitkajarvi 1990 & $8 / 174$ & $6 / 171$ & $\longrightarrow$ & 3.0 & $1.31[0.46,3.70]$ \\
\hline Richards 1984 & $5 / 92$ & $9 / 86$ & $\longrightarrow$ & 3.0 & $0.52[0.18,1.49]$ \\
\hline Sandberg 1985 & $4 / 102$ & $6 / 100$ & $\longrightarrow$ & 2.2 & $0.65[0.19,2.25]$ \\
\hline Trienekens 1989 & $22 / 161$ & $34 / 166$ & 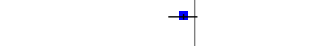 & 10.9 & $0.67[0.41,1.09]$ \\
\hline Tsugawa 1999 & $2 / 45$ & $3 / 50$ & ?. & 1.1 & $0.74[0.13,4.23]$ \\
\hline Subtotal $(95 \% \mathrm{Cl})$ & 1679 & 1721 & $\bullet$ & 54.4 & $0.77[0.61,0.97]$ \\
\hline \multicolumn{6}{|c|}{ Total events: II4 (Three days), I53 (5-10 days) } \\
\hline \multicolumn{6}{|c|}{ Test for heterogeneity chi-square $=7.96 \mathrm{df}=12 \mathrm{p}=0.79 \mathrm{I}^{2}=0.0 \%$} \\
\hline \multicolumn{6}{|c|}{ Test for overall effect $z=2.17 \quad p=0.03$} \\
\hline \multicolumn{6}{|c|}{02 Different antibiotic therapy in each group } \\
\hline Bitsch 1985 & $6 / 158$ & $3 / 152$ & L & 1.8 & $1.92[0.49,7.56]$ \\
\hline Cox 1992 & $7 / 101$ & $10 / 99$ & $\longrightarrow$ & 3.7 & $0.69[0.27,1.73]$ \\
\hline Guibert 1997 & $8 / 212$ & $10 / 209$ & $\longrightarrow$ & 3.9 & $0.79[0.32,1.96]$ \\
\hline Henry 1999 & $42 / 394$ & $46 / 386$ & - & 14.8 & $0.89[0.60,1.33]$ \\
\hline Hooton 1991 & $7 / 49$ & $8 / 47$ & $\longrightarrow$ & 3.7 & $0.84[0.33,2.13]$ \\
\hline Iravani 1999 & $8 / 239$ & $48 / 474$ & $\rightarrow$ & 5.7 & $0.33[0.16,0.69]$ \\
\hline \multirow[t]{3}{*}{ Menday 2000} & $11 / 219$ & $5 / 221$ & . & 3.0 & $2.22[0.78,6.28]$ \\
\hline & & & $0.01 \quad 0.1$ & 100 & \\
\hline & & & Favours three days & 10 days & (Continued. \\
\hline
\end{tabular}

Duration of antibacterial treatment for uncomplicated urinary tract infection in women (Review) 


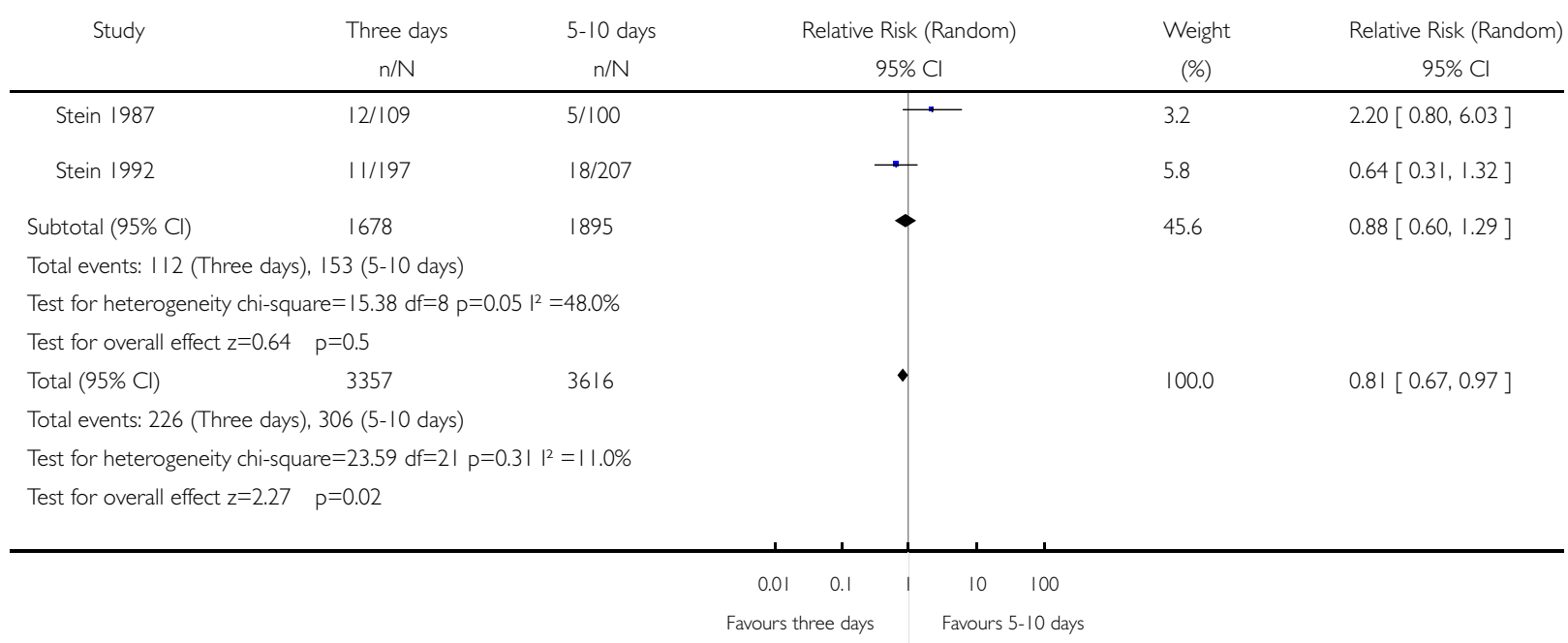

\section{Analysis 0I.16. Comparison 0 I Three days versus 5-10 day antibiotic therapy, Outcome I6 Skin adverse effects}

Review: Duration of antibacterial treatment for uncomplicated urinary tract infection in women

Comparison: 01 Three days versus 5-10 day antibiotic therapy

Outcome: 16 Skin adverse effects

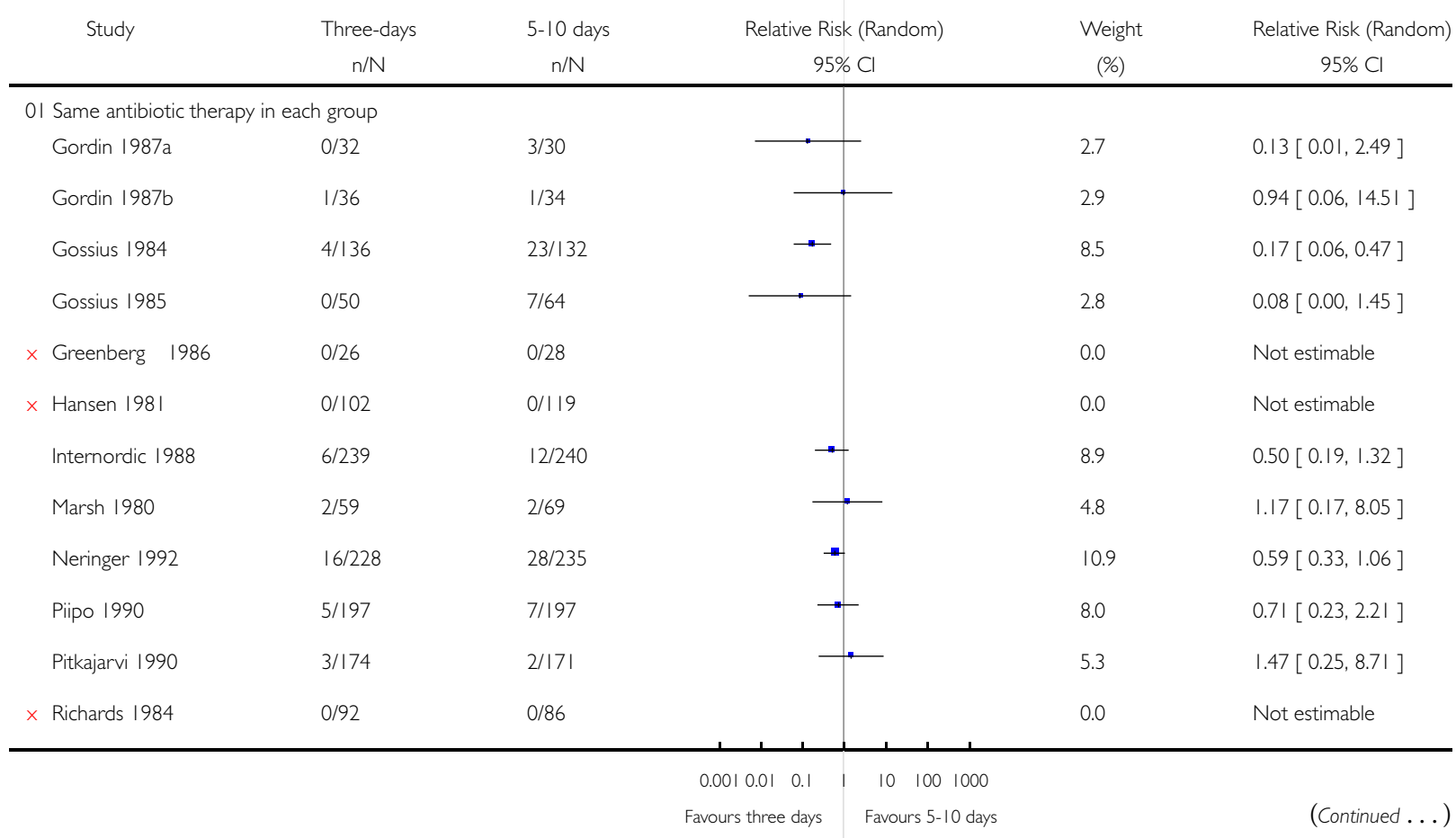

Duration of antibacterial treatment for uncomplicated urinary tract infection in women (Review) 


\begin{tabular}{|c|c|c|c|c|c|}
\hline Study & $\begin{array}{c}\text { Three-days } \\
\mathrm{n} / \mathrm{N}\end{array}$ & $\begin{array}{l}5-10 \text { days } \\
n / N\end{array}$ & $\begin{array}{l}\text { Relative Risk (Random) } \\
\qquad 95 \% \mathrm{Cl}\end{array}$ & $\begin{array}{l}\text { Weight } \\
(\%)\end{array}$ & $\begin{array}{l}\text { Relative Risk (Random) } \\
95 \% \mathrm{Cl}\end{array}$ \\
\hline Sandberg 1985 & 1/102 & $0 / 100$ & \begin{tabular}{l|l}
$\cdot$ & $r$ \\
\end{tabular} & 2.3 & $2.94[0.12,71.37]$ \\
\hline Trienekens 1989 & $3 / 161$ & $6 / 166$ & $\rightarrow$ & 6.9 & $0.52[0.13,2.03]$ \\
\hline Subtotal $(95 \% \mathrm{Cl})$ & 1634 & 1671 & $\bullet$ & 63.9 & $0.51[0.34,0.77]$ \\
\hline \multicolumn{6}{|c|}{ Total events: 4I (Three-days), 9I (5-10 days) } \\
\hline \multicolumn{6}{|c|}{ Test for heterogeneity chi-square $=10.98 \mathrm{df}=10 \mathrm{p}=\left.0.36\right|^{2}=8.9 \%$} \\
\hline \multicolumn{6}{|c|}{ Test for overall effect $z=3.17 \quad p=0.002$} \\
\hline \multicolumn{6}{|c|}{02 Different antibiotic therapy in each group } \\
\hline Bitsch 1985 & $0 / 158$ & $2 / 152$ & - & 2.5 & $0.19[0.01,3.98]$ \\
\hline Guibert 1997 & $5 / 212$ & 2/209 & - & 5.8 & $2.46[0.48,12.56]$ \\
\hline Henry 1999 & $27 / 394$ & 6/386 & - & 9.4 & $4.41[1.84,10.56]$ \\
\hline Iravani 1999 & $3 / 239$ & $10 / 474$ & & 7.3 & $0.59[0.17,2.14]$ \\
\hline Menday 2000 & $2 / 219$ & 7/221 & 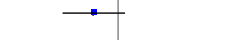 & 6.1 & $0.29[0.06,1.37]$ \\
\hline Stein 1987 & 0/109 & $7 / 100$ & - & 2.8 & $0.06[0.00,1.06]$ \\
\hline Stein 1992 & 0/197 & 1/207 & - & 2.3 & $0.35[0.01,8.54]$ \\
\hline Subtotal $(95 \% \mathrm{Cl})$ & 1528 & 1749 & & 36.1 & $0.69[0.21,2.28]$ \\
\hline \multicolumn{6}{|c|}{ Total events: 37 (Three-days), 35 (5-10 days) } \\
\hline \multicolumn{6}{|c|}{ Test for heterogeneity chi-square $=19.87 \mathrm{df}=6 \mathrm{p}=0.003 \mathrm{I}^{2}=69.8 \%$} \\
\hline \multicolumn{6}{|c|}{ Test for overall effect $z=0.61 \quad p=0.5$} \\
\hline Total (95\% Cl) & 3162 & 3420 & $\bullet$ & 100.0 & $0.62[0.36,1.06]$ \\
\hline \multicolumn{6}{|c|}{ Total events: 78 (Three-days), 126 (5-10 days) } \\
\hline \multicolumn{6}{|c|}{ Test for heterogeneity chi-square $=37.71 \mathrm{df}=17 \mathrm{p}=0.003 \mathrm{I}^{2}=54.9 \%$} \\
\hline Test for overall effec & $=0.08$ & & & & \\
\hline
\end{tabular}

$0.0010 .010 .1 \quad 1 \quad 10 \quad 100 \quad 1000$

Favours three days Favours 5-10 days 


\section{Analysis 01.17. Comparison 01 Three days versus 5-10 day antibiotic therapy, Outcome I7 CNS adverse}

effects

Review: Duration of antibacterial treatment for uncomplicated urinary tract infection in women

Comparison: 01 Three days versus 5-10 day antibiotic therapy

Outcome: 17 CNS adverse effects

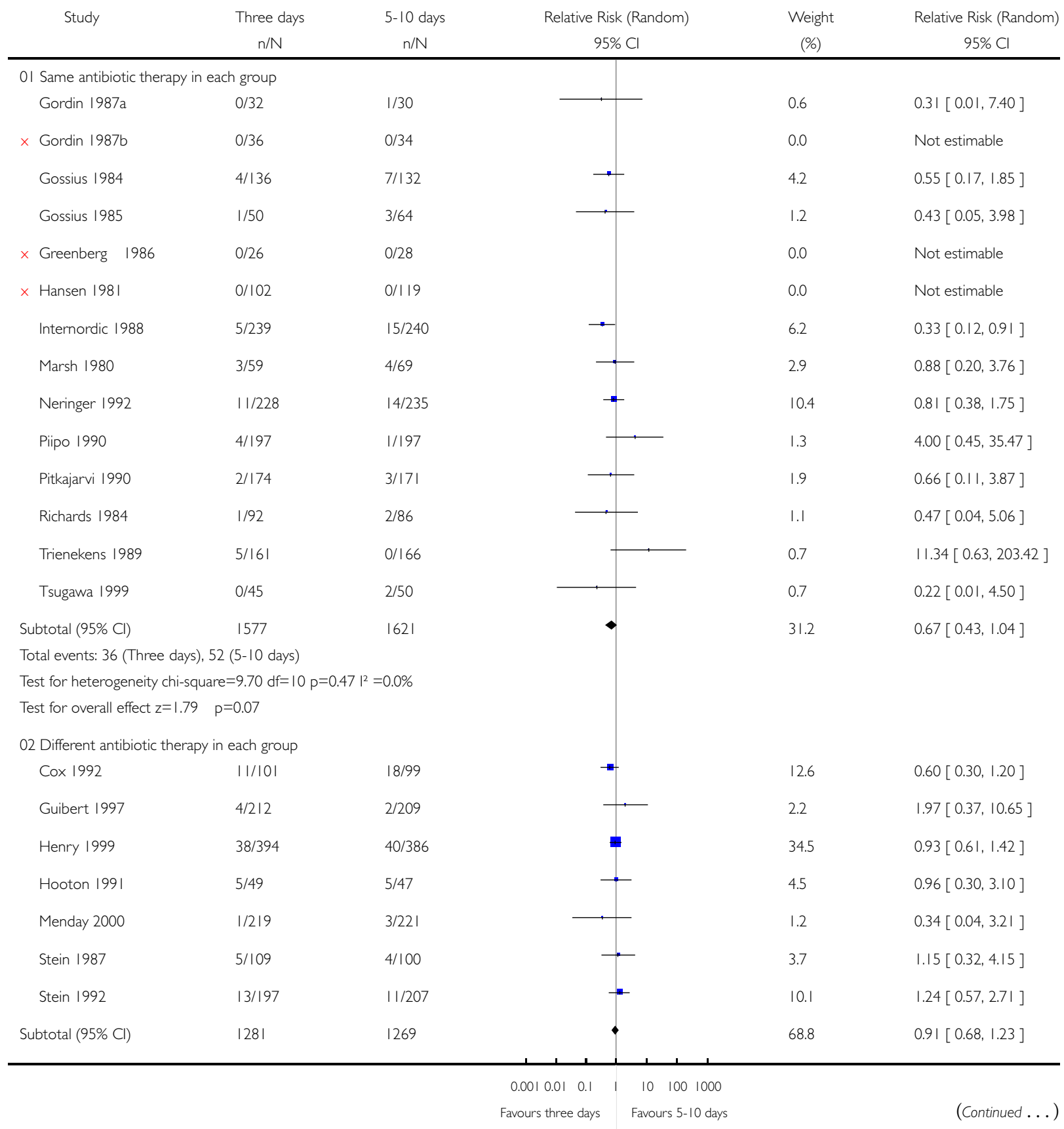

Duration of antibacterial treatment for uncomplicated urinary tract infection in women (Review) 


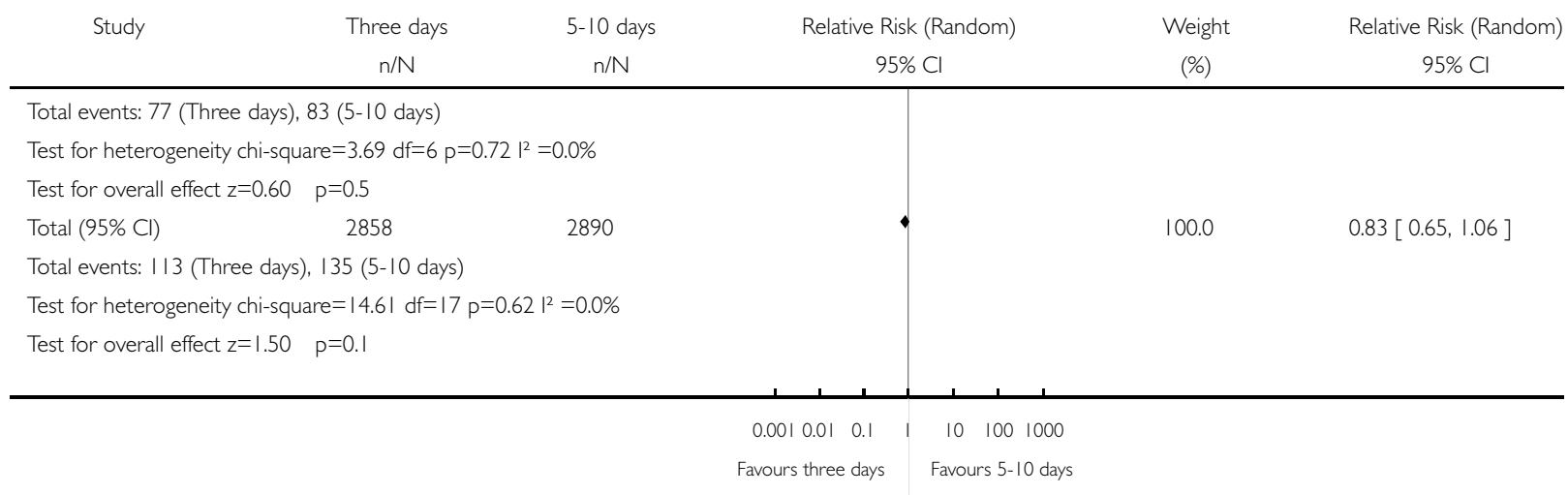

\section{Analysis 01.18. Comparison 01 Three days versus 5-10 day antibiotic therapy, Outcome I8 Vaginal discharge} as an adverse effect of therapy

Review: Duration of antibacterial treatment for uncomplicated urinary tract infection in women

Comparison: 01 Three days versus 5-10 day antibiotic therapy

Outcome: 18 Vaginal discharge as an adverse effect of therapy

\begin{tabular}{cccc} 
Three days & $5-10$ days & Relative Risk (Random) & Weight \\
$n / N$ & $n / N$ & $95 \% \mathrm{Cl}$ & $(\%)$ \\
\hline
\end{tabular}

0I Same antibiotic therapy in each group

$\times$ Gordin 1987a 0/32

$0 / 30$

Gordin 1987b

$1 / 36$

$2 / 34$

Gossius 1984

$0 / 136$

$3 / 132$

$\times$ Gossius 1985

$0 / 50$

0/64

Greenberg 1986

$0 / 26$

$1 / 28$

$\times$ Hansen 1981

0/102

$0 / 119$

Neringer 1992

$5 / 228$

2/235

Pitkajarvi 1990

0/174

4/171

Richards 1984

0/92

1/86

Sandberg 1985

$4 / 102$

$5 / 100$

Trienekens 1989

$2 / 161$

1/166

Subtotal $(95 \% \mathrm{Cl})$

1139

1165

Total events: 12 (Three days), 19 (5- 10 days)

Test for heterogeneity chi-square $=6.59 \mathrm{df}=7 \mathrm{p}=0.47 \mathrm{I}^{2}=0.0 \%$

Test for overall effect $z=0.74 \quad p=0.5$

02 Different antibiotic therapy in each group

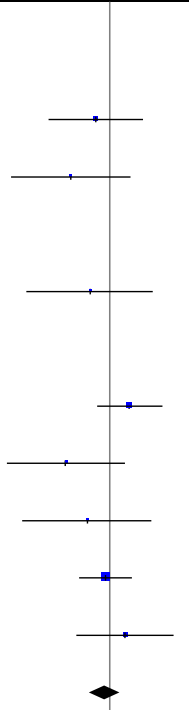

0.0

2.9

1.9

0.0

1.6

0.0

6.1

1.9

1.6

9.8

2.8

28.7
Not estimable

$0.47[0.04,4.97]$

$0.14[0.01,2.66]$

Not estimable

$0.36[0.02,8.42]$

Not estimable

$2.58[0.51,13.15]$

$0.11[0.01,2.01]$

$0.31[0.01,7.55]$

$0.78[0.22,2.84]$

$2.06[0.19,22.52]$

$0.75[0.35,1.59]$

$\begin{array}{lllllll}0.001 & 0.01 & 0.1 & 1 & 10 & 100 & 1000\end{array}$

Favours three days Favours 5-10 days

(Continued ... ) 


\begin{tabular}{|c|c|c|c|c|c|}
\hline Study & $\begin{array}{l}\text { Three days } \\
n / N\end{array}$ & $\begin{array}{c}5-10 \text { days } \\
n / N\end{array}$ & $\begin{array}{c}\text { Relative Risk (Random) } \\
\qquad 95 \% \mathrm{Cl}\end{array}$ & $\begin{array}{c}\text { Weight } \\
(\%)\end{array}$ & $\begin{array}{c}\text { Relative Risk (Random) } \\
\qquad 95 \% \mathrm{Cl}\end{array}$ \\
\hline Cox 1992 & $1 / 10 \mid$ & $4 / 99$ & $\longrightarrow$ & 3.4 & $0.25[0.03,2.15]$ \\
\hline Guibert 1997 & $9 / 212$ & $8 / 209$ & $\rightarrow$ & 18.7 & I.1। $[0.44,2.82]$ \\
\hline Henry 1999 & $14 / 394$ & $15 / 386$ & 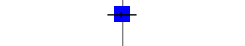 & 31.8 & $0.91[0.45,1.87]$ \\
\hline Hooton |99| & $2 / 49$ & $5 / 47$ & $\longrightarrow$ & 6.4 & $0.38[0.08,1.88]$ \\
\hline Iravani 1999 & $0 / 239$ & $5 / 474$ & \begin{tabular}{l|l}
$\cdots$ \\
\end{tabular} & 1.9 & $0.18[0.01,3.24]$ \\
\hline Stein 1987 & $1 / 109$ & $2 / 100$ & $\cdot$ & 2.9 & $0.46[0.04,4.98]$ \\
\hline Stein 1992 & $2 / 197$ & $5 / 207$ & $\longrightarrow$ & 6.1 & $0.42[0.08,2.14]$ \\
\hline Subtotal $(95 \% \mathrm{Cl})$ & $|30|$ & 1522 & $\bullet$ & 71.3 & $0.73[0.45,1.17]$ \\
\hline \multicolumn{6}{|c|}{ Total events: 29 (Three days), 44 (5-10 days) } \\
\hline \multicolumn{6}{|c|}{ Test for heterogeneity chi-square $=4.30 \mathrm{df}=6 \mathrm{p}=0.64 \mathrm{l}^{2}=0.0 \%$} \\
\hline \multicolumn{6}{|c|}{ Test for overall effect $z=1.31 \quad p=0.2$} \\
\hline Total $(95 \% \mathrm{Cl})$ & 2440 & 2687 & $\bullet$ & 100.0 & $0.73[0.49,1.10]$ \\
\hline \multicolumn{6}{|c|}{ Total events: 41 (Three days), 63 (5-10 days) } \\
\hline \multicolumn{6}{|c|}{ Test for heterogeneity chi-square $=10.88 \mathrm{df}=\mid 4 \mathrm{p}=0.70 \mathrm{I}^{2}=0.0 \%$} \\
\hline Test for overall effe & $=0.1$ & & & & \\
\hline
\end{tabular}

\section{Analysis 01.19. Comparison 01 Three days versus 5-10 day antibiotic therapy, Outcome 19 Other adverse} effects

Review: Duration of antibacterial treatment for uncomplicated urinary tract infection in women

Comparison: 01 Three days versus 5-10 day antibiotic therapy

Outcome: 19 Other adverse effects

$$
\text { Study Three days }
$$

$\mathrm{n} / \mathrm{N}$

5-10 days

Relative Risk (Random)

Weight

$95 \% \mathrm{C}$

(\%)

Relative Risk (Random)

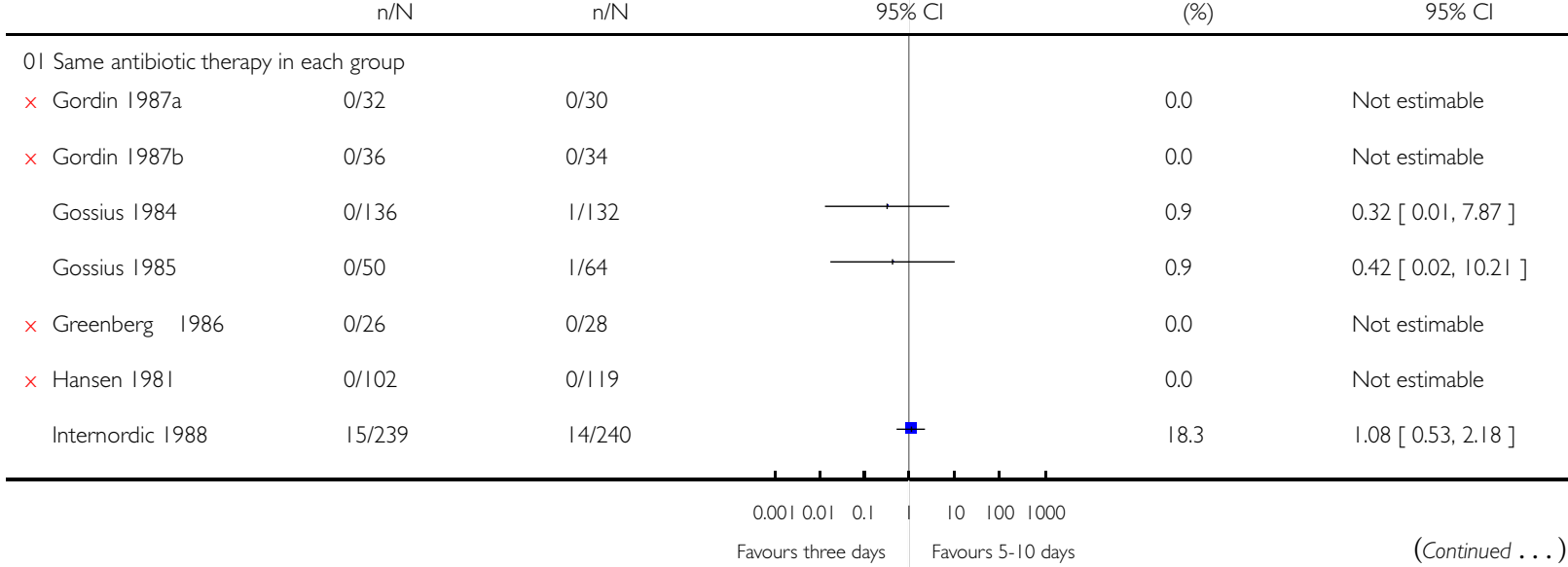

Duration of antibacterial treatment for uncomplicated urinary tract infection in women (Review) 


\begin{tabular}{|c|c|c|c|c|c|}
\hline Study & $\begin{array}{c}\text { Three days } \\
n / N\end{array}$ & $\begin{array}{c}5-10 \text { days } \\
n / N\end{array}$ & $\begin{array}{l}\text { Relative Risk (Random) } \\
\qquad 95 \% \mathrm{Cl}\end{array}$ & $\begin{array}{l}\text { Weight } \\
(\%)\end{array}$ & $\begin{array}{c}\text { Relative Risk (Random) } \\
95 \% \mathrm{Cl}\end{array}$ \\
\hline Marsh 1980 & $3 / 59$ & $2 / 69$ & $\longrightarrow$ & 3.0 & $1.75[0.30,10.15]$ \\
\hline Neringer 1992 & $5 / 228$ & $7 / 235$ & $\rightarrow$ & 7.1 & $0.74[0.24,2.29]$ \\
\hline Piipo 1990 & $6 / 197$ & $4 / 197$ & $\rightarrow$ & 5.9 & $1.50[0.43,5.23]$ \\
\hline Pitkajarvi 1990 & $8 / 174$ & $5 / 171$ & $\rightarrow$ & 7.6 & $1.57[0.52,4.7 \mid]$ \\
\hline Richards 1984 & 2/92 & $3 / 86$ & $\longrightarrow$ & 2.9 & $0.62[0.11,3.64]$ \\
\hline Sandberg 1985 & $1 / 102$ & $1 / 100$ & $\longrightarrow$ & 1.2 & $0.98[0.06,15.46]$ \\
\hline Trienekens 1989 & $8 / 161$ & $10 / 166$ & $\rightarrow$ & 11.2 & $0.82[0.33,2.04]$ \\
\hline Tsugawa 1999 & $2 / 45$ & $0 / 50$ & 7 & 1.0 & $5.54[0.27,112.47]$ \\
\hline Subtotal $(95 \% \mathrm{Cl})$ & 1679 & 1721 & $\bullet$ & 60.0 & $1.05[0.71,1.55]$ \\
\hline \multicolumn{6}{|c|}{ Total events: 50 (Three days), 48 (5-10 days) } \\
\hline \multicolumn{6}{|c|}{ Test for heterogeneity chi-square $=4.16 \mathrm{df}=10 \mathrm{p}=0.94 \mathrm{I}^{2}=0.0 \%$} \\
\hline \multicolumn{6}{|c|}{ Test for overall effect $z=0.25 \quad p=0.8$} \\
\hline \multicolumn{6}{|c|}{02 Different antibiotic therapy in each group } \\
\hline Guibert 1997 & $18 / 212$ & $18 / 209$ & $=$ & 23.4 & $0.99[0.53,1.84]$ \\
\hline Henry 1999 & $9 / 394$ & $7 / 386$ & - & 9.6 & $1.26[0.47,3.35]$ \\
\hline Menday 2000 & $3 / 219$ & $9 / 221$ & $\rightarrow$ & 5.5 & $0.34[0.09,1.23]$ \\
\hline Stein 1987 & $1 / 109$ & $2 / 100$ & $\cdot \cdot$ & 1.6 & $0.46[0.04,4.98]$ \\
\hline Subtotal $(95 \% \mathrm{Cl})$ & 934 & 916 & $\bullet$ & 40.0 & $0.87[0.53,1.42]$ \\
\hline \multicolumn{6}{|c|}{ Total events: 31 (Three days), 36 (5- 10 days) } \\
\hline \multicolumn{6}{|c|}{ Test for heterogeneity chi-square $=3.07 \mathrm{df}=3 \mathrm{p}=0.38 \mathrm{I}^{2}=2.3 \%$} \\
\hline \multicolumn{6}{|c|}{ Test for overall effect $z=0.55 \quad p=0.6$} \\
\hline Total $(95 \% \mathrm{Cl})$ & 2613 & 2637 & $\bullet$ & 100.0 & $0.98[0.72,1.32]$ \\
\hline \multicolumn{6}{|c|}{ Total events: 81 (Three days), 84 (5-10 days) } \\
\hline \multicolumn{6}{|c|}{ Test for heterogeneity chi-square $=7.56 \mathrm{df}=|4 \mathrm{p}=0.9| \mathrm{I}^{2}=0.0 \%$} \\
\hline Test for overall effec & $p=0.9$ & & & & \\
\hline
\end{tabular}

$0.0010 .010 .1 \quad 1 \quad 10 \quad 100 \quad 1000$

Favours three days Favours $5-10$ days 
Analysis 01.20. Comparison 01 Three days versus 5-10 day antibiotic therapy, Outcome 20 Patients with any adverse effects during treatment by antibiotic class (same drug)

Review: Duration of antibacterial treatment for uncomplicated urinary tract infection in women

Comparison: 01 Three days versus 5-10 day antibiotic therapy

Outcome: 20 Patients with any adverse effects during treatment by antibiotic class (same drug)

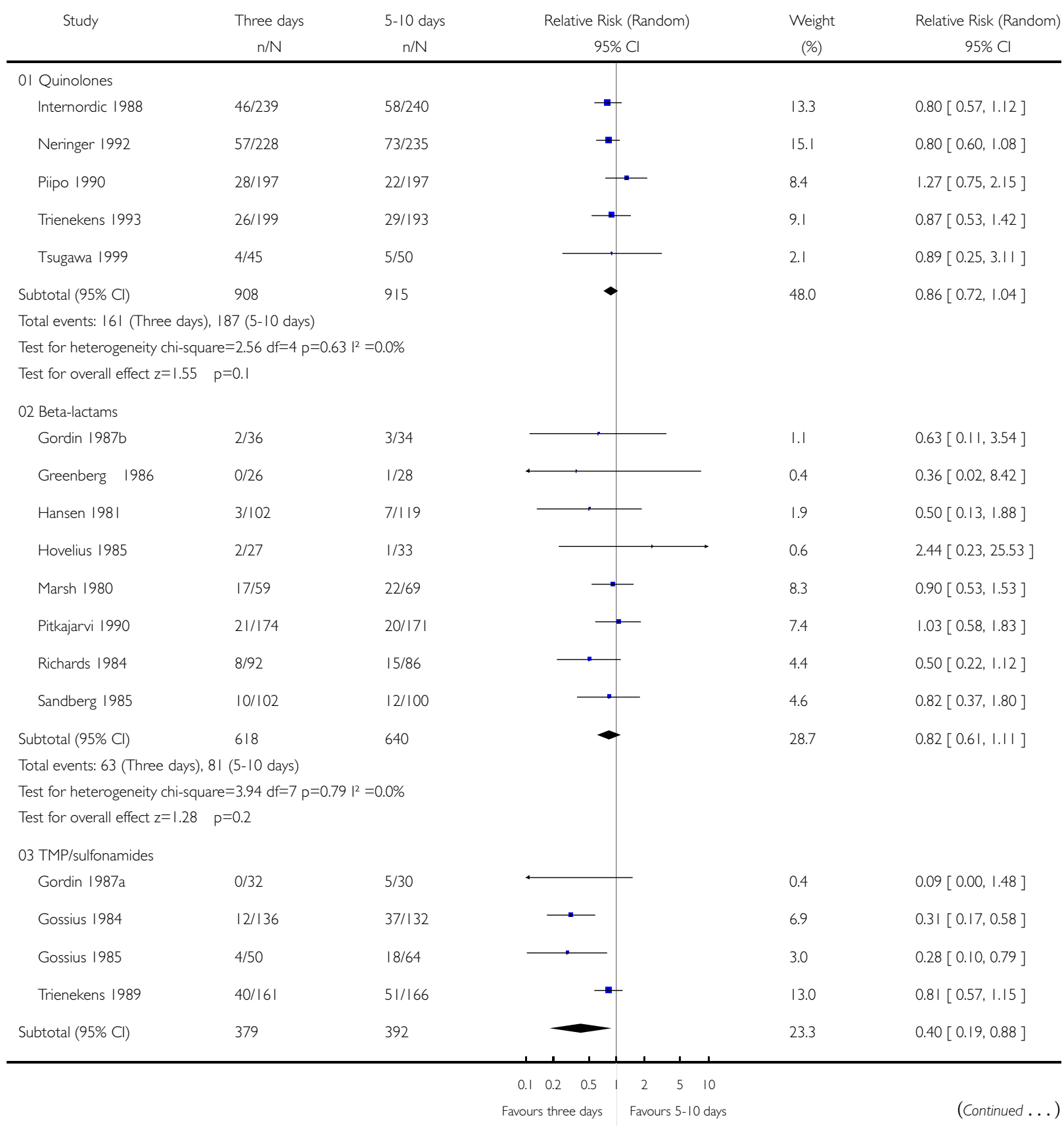

Duration of antibacterial treatment for uncomplicated urinary tract infection in women (Review) 


\begin{tabular}{|c|c|c|c|c|c|}
\hline Study & $\begin{array}{c}\text { Three days } \\
n / N\end{array}$ & $\begin{array}{l}5-10 \text { days } \\
n / N\end{array}$ & $\begin{array}{l}\text { Relative Risk (Random) } \\
\qquad 95 \% \mathrm{Cl}\end{array}$ & $\begin{array}{l}\text { Weight } \\
(\%)\end{array}$ & $\begin{array}{c}\text { Relative Risk (Random) } \\
\qquad 95 \% \mathrm{Cl}\end{array}$ \\
\hline \multicolumn{6}{|c|}{ Total events: 56 (Three days), 11 I (5-10 days) } \\
\hline \multicolumn{6}{|c|}{ Test for heterogeneity chi-square $=11.44 \mathrm{df}=3 \mathrm{p}=0.01 \mathrm{I}^{2}=73.8 \%$} \\
\hline \multicolumn{6}{|c|}{ Test for overall effect $z=2.30 \quad p=0.02$} \\
\hline Total $(95 \% \mathrm{Cl})$ & 1905 & 1947 & $\bullet$ & 100.0 & $0.76[0.63,0.92]$ \\
\hline \multicolumn{6}{|c|}{ Total events: 280 (Three days), 379 (5-10 days) } \\
\hline \multicolumn{6}{|c|}{ Test for heterogeneity chi-square $=22.63 \mathrm{df}=16 p=0.12 \mathrm{I}^{2}=29.3 \%$} \\
\hline \multicolumn{6}{|c|}{ Test for overall effect $z=2.87 \quad p=0.004$} \\
\hline
\end{tabular}

